
AFGHANISTAN. 



\section{A F GHANISTAN :}

A SHORT ACCOUNT OF AFGHANISTAN, ITS HISTORY, AND OUR DEALINGS

WITH IT.

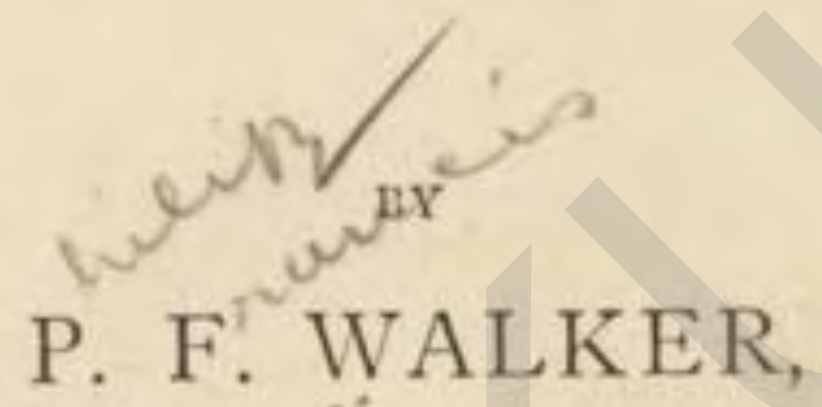

BARRISTER-AT-LAW. (I.ATE 75TH REGIMENT.)
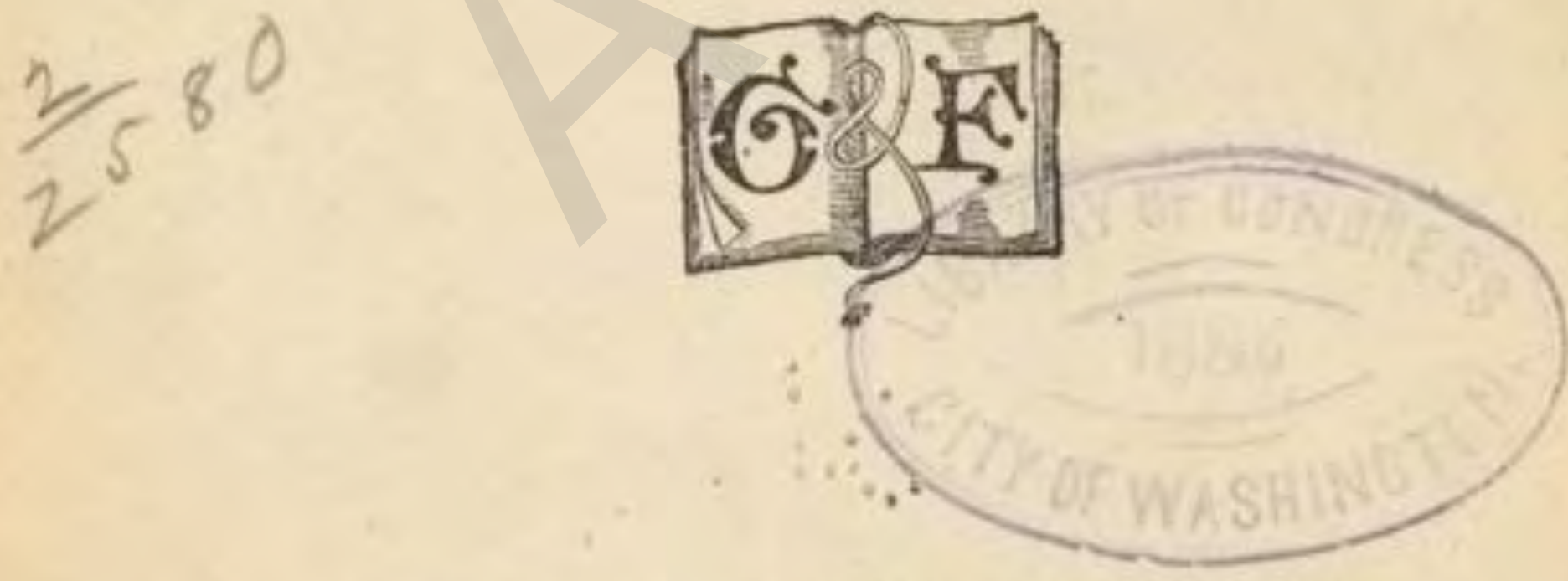

GRIFFITH AND FARRAN,

SUCCESSORS TO NEWBERY AND HARRIS,

WEST CORNER OF ST. PAUL'S CHURCHYARD, LONDON.

E. P. DUTTON AND CO., NEW YORK.

I88 r. 


$$
\begin{aligned}
& 53^{36} \\
& \times 18
\end{aligned}
$$

[The rights of Translation and of Reproduction are reserved.] 


\section{3}

\section{PREFACE.}

THE object of this book is to lay before the public a short history of Afghanistan, which, can be read in a few hours, and will give, the author trusts, an accurate account of the history of a country at the present time attracting considerable attention from the importance of its position in relation to our Indian Empire.

The author having been present in Afghanistan during part of the Afghan war, is able in these pages to supply some details from his personal experience as well as information derived on the spot; for the rest, he wishes to express the obligations he is under towards the authorities from whom he has derived his information; they areKaye's "Afghanistan War," various histories 
of India, Elphinstone's “ Kingdo m of Cabul," the "Account of the Massacre of the Cabul Army," by Lieutenant Eyre, Malleson's "History of Afghanistan," and other books, together with letters and articles in various magazines and newspapers.

Temple, January, r88 r. 


\section{AFGHANISTAN.}

In this book I propose to lay before the reader a short account of the history of Afghanistan from the earliest time to the present day, including accounts of our first Afghan war of $183_{3} 8-42$, the present war, and the Afghan question.

I do not propose to enlarge upon the geography of the country, but simply to state roughly the boundaries of Afghanistan.

Afghanistan is bounded on the north by the Oxus river, and a line drawn from that river to Persia, dividing Afghanistan from Khivan territory. On the west Afghanistan is bounded by Persia; on the south by Beloochistan; on the south-east by British India, from which it is clearly separated by the Suliman and Safed Koh ranges of mountains; on the east Afghanistan is bounded by 
Cashmeer. Originally the Afghanistan that I have here described was only part of a kingdom whose capital was Bokhara.

All invaders of India coming from the north have passed through Afghanistan. As far back as the year 5 I 8 B.C. Darius, King of Persia, crossed the Indus, and annexed a large portion of the north of India to his kingdom.

Alexander the Great was the next invader of India. Having subjugated Cabul about 33I в.c., he passed the mountains, crossed the Indus at Attock, and defeated King Porus on the Jhelum river; thence he pushed on as far as the Sutlej, which he was compelled to make his boundary, as his troops could not be induced to advance further, though he himself desired to traverse the districts bordering on the Ganges, of whose wealth he had received fabulous reports.

In A.D. IOOI we hear of the next important invasion of India from the north, by Mahmood of Ghuzni. This king in several expeditions conquered a large part of northern India, penetrating as far as Somnath, from whence he removed the sandal-wood gates of a celebrated Hindoo temple to Ghuzni in 
1024. These gates afterwards became the subject of Lord Ellenborough's "Proclamation of the Gates," of which I shall say more hereafter. Under this king Ghuzni rose to be one of the most splendid cities of the world, filled with marble palaces and treasures, and so remained until I $5_{52}$, when it was sacked and greatly destroyed by Alla-ood-deen. The dynasty of Mahmood of Ghuzni lasted until I 186.

The next rulers of Afghanistan were those usually known as the House of Ghore, of whom Mahomed Ghory was the most renowned. He invaded India from Afghanistan, defeated the King of Delhi and his allies, and established the second Mahommedan dynasty at Delhi. His empire was further pushed on by his commanders over Behar and Bengal. This prince died in 1206.

Shortly afterwards Jenghis Khan, the ruler of the Moguls, a tribe of Tartars, laid waste the whole of Central Asia, and marched as far as the Indus.

In 1298 the Moguls again attempted an invasion of India, but were defeated near Delhi.

A hundred years later, namely, in 1398 , 
Timur, or, as he is sometimes called, Tamerlane, having made himself master of Central Asia, advanced to the conquest of India. Crossing the Indus at Attock, he plundered the country as far as Delhi, after which he returned and recrossed the river.

The next invasion of India from the north was that of Baber, in $5_{5} \mathrm{I} 9$. Baber was the sixth in descent from Timur; he had captured Cabul in 1504, and had there maintained himself, notwithstanding perpetual warfare against the Uzbeks. After four expeditions against India with doubtful results, he finally, in 1526 , met the Emperor Ibrahim Lodi in the plain of Paniput. In the battle fought there Baber was completely successful, and seated himself on the throne of Delhi.

It is extraordinary to find the numbers recorded as opposed to each other in this battle, it is said that Baber's army consisted of but 12,000 men, all hardy veterans, while Ibrahim Lodi's army numbered nearly 100,000 men; the battle lasted the whole day, and resulted in the complete defeat of the Emperor of Delhi, who lost 15,000 men, and was himself killed. After conquering Chunderee, Oude, and Behar, Baber died in 1530. His body was carried from Agra to 
Cabul. His son Humayoon succeeded him on the throne of Delhi, but being defeated by Shere Khan, he was finally driven out of India in 1540 . However, in 1545 , having obtained assistance from Shah Tamasp, the Persian monarch, he attacked and took Candahar, and made himself master of Cabul; and shortly afterwards, taking advantage of the weakness and profligacy of Adeli, who was now Emperor at Delhi, Humayoon crossed the Indus once more in I555, and defeated the forces sent against him. He now for a second time mounted the throne of Delhi; six months later, however, he slipped on the marble floor of his palace, and received injuries from which he died. He was succeeded by the greatest of the Moguls, Akbar. Akbar was not, however, allowed to succeed quietly to his father's throne, for he was attacked by Hemu, a Hindoo who was in command of Sultan Adeli's army, and again, for the second time, the plair of Paniput was the scene of a great battle in which the rulers of Afghanistan attempted to obtain possession of the throne of Delhi; after a severe contest, the army of Sultan Adeli was completely defeated, and its gallant general Hemu taken prisoner 
and put to death. This battle seated Akbar securely on the throne of Delhi, ${ }_{5} 56$.

Bengal and Orissa had both been governed by descendants of the first conquering Afghans, until in 1576 Daood Khan was defeated and slain by Akbar's generals, and with him terminated the rule of those Afghans in the two provinces, a rule that had lasted over 200 years.

Akbar was now master of the greater part of India, but there still remained to him to reduce the north-western border-tribes of Khyberees and hill-men, who could not be restrained from their predatory expeditions, by either threats or liberality.

For this purpose Akbar sent against them a strong force ; the expedition was, however, most disastrous, 40,000 men having been said to have been cut off in the mountain passes and destroyed. Akbar then adopted a different mode of warfare against these tribes, and established a chain of fortified posts throughout the mountains, from whence his garrisons were able to sally out whenever the hill-men collected, and by which the hill-men were cut off from their supplies, and communications with the plains; and this plan seems to have succeeded fairly well, 
though it had not the effect of civilizing or taming the people. During the reign of Akbar and his successors, Candahar was frequently lost and regained by them in their struggles with Persia, until the power of the Court of Delhi being weakened by continual dissensions and rebellions, and the incapacity of the monarchs having destroyed the strength of the state, Afghanistan was left free from all control from India; and Candahar, with a large part of the country, fell under the power of the Shahs of Persia, Abbas II., and his successor Suliman. In I 709 the Ghilzie Afghans revolted, and made Candahar independent of the Persian Crown ; and finally in 1722 Mahmood, the Ghilzie Chief, took Ispahan, and became King of Persia. On the death of Mahmood his son succeeded him, and Afghanistan remained in a state of semi-independence until Nadir Shah became powerful in Khorassan. This extraordinary man defeated the Abdali Afghans in Khorassan, the Ghilzies in Persia, and the Turks and Russians in the west, and having been crowned king, he invaded Afghanistan, and laid siege to Candahar; from thence he sent messengers to Delhi; one of his messengers, however, received but 
little attention, while another was murdered on his journey. Exasperated by this treatment, Nadir Shah determined to invade. India. Having crossed the Indus with a large army, he defeated the Emperor of Delhi, and entered the city with him in 1739 . A short time after his arrival at Delhi a disturbance arose between the inhabitants of the city and Nadir's army, from which a general massacre of the inhabitants ensued. After having inflicted this terrible massacre on the people of Delhi, and after having plundered the whole country, and collected enormous spoils, Nadir Shah returned to Persia, leaving Mahomed Shah restored to the throne of Delhi, but extending his own territories to the Indus. Nadir Shah, whose career had been from its commencement marked by cruelty, treachery, and baseness, was assassinated in his tent by his own people in 1747 .

His throne was seized upon by Ahmed Khan, an Abdali Afghan, of the Sudoozie family, a name which he shortly afterwards changed to Durani, which name they at present bear. He advanced into India, but was defeated by the army of the Emperor of Delhi.

Not dispirited, however, by his defeat, and 
seeing that the country was in a state of great confusion owing to the death of the Emperor Mahomed Shah, Ahmed Shah Abdali again advanced into India, and made himself master of the Northern provinces. These provinces were afterwards confirmed to him by treaty. Disputes having again broken out between Ahmed Shah Abdali and the Court of Delhi, he for the third time advanced into India, captured and sacked Delhi, and again retired across the Indus.

Ahmed Shah then leaving Timur, his son, in charge of the Indian provinces, returned to the North.

The next year Timur was attacked by the Mahrattas, and defeated. In order to avenge this defeat, in 1759, Ahmed Shah once more commenced an invasion of India ; in this, his fourth invasion, he defeated the armies of Scindia and Holkar, who were opposed to him; and finally in January, 1,61 , at Paniput, where already twice before the fate of India had been decided, he encountered the whole Mahratta power. For days the two armies lay opposed to each other without any decisive action taking place, but at last reduced by famine, and by sickness engendered by the dead bodies around their camp, the Mahrat- 
tas commenced the attack. Their army had been one of the finest that India had ever seen, and was estimated at over 250,000 men, while that of Ahmed Shah consisted of but about 80,000 ; but famine had greatly reduced the ranks and strength of the Mahrattas. The battle was fiercely contested, and at one time it appeared as if the victory would remain with the Mahrattas, but Ahmed Shah brought up his reserve, some of the Mahratta chiefs fell, and others withdrew; thereupon the Mahratta army was thrown into confusion, and victory remained with the invader. The loss of the Mahrattas in this campaign was estimated at 200,000 men; had they gained the day, the fortunes of India would have been changed; for they would then have been the greatest power in the country, and we ourselves should perhaps not have obtained the hold that we now have in India. After this decisive victory of Paniput, Ahmed Shah Abdali remained master of India, since having destroyed the strength of the Mahrattas, there was no other power that could cope with him ; but it was not his policy to become Emperor of Delhi, he therefore retired into Afghanistan, after having restored the almost nominal sovereignty of the Mogul, 
a sovereignty which was destined to last until the Indian mutiny. Shortly after his return to Afghanistan, Ahmed Shah died, and was succeeded by his son Timur, who moved the capital of his kingdom from Candahar to Cabul, as he distrusted both the Candahar people and the Duranis, who had supported his brother against him on his father's death. Timur governed the country well, and collected the taxes regularly, so that without wars his exchequer was full, still he was troubled with rebellions on all sides, the lightness of his rule leading the chiefs to imagine that they could rebel with impunity. This prince died in 1793 , leaving twenty-three sons, of whom Zemaun Shah was chosen as king; but although chosen king, his kingdom had to be conquered, for there were signs of revolt amongst various chiefs, and two of his brothers were in open rebellion. Nevertheless, by rapid and determined movements, he counteracted the plans of his brothers, and having settled Cabul and Candahar, he marched his army through the mountains into India, and made himself master of Lahore and the Punjab. In 1798, Lord Wellesley, then Governor-General of India, received a letter from Zemaun Shah, stating his proposed expe- 
dition into India, and requesting the co-operation of the English army for the purpose of driving back the Mahrattas from the north into the Deccan; Scindia and Holkar having invaded Delhi and Agra some years previously. The power of Zemaun Shah was not at that time known to be as weak as it really was, for judged by the history of his grandfather's reign, he was supposed to be a powerful prince. Nevertheless Lord Wellesley, with the object of securing a treaty with Scindia, sent Zemaun Shah's letter to him, saying that it was the desire of the British Government to maintain the present princes of India in the position they then occupied. Lord Wellesley did this with the object of checking Tippoo Sultan, who was at this time making great preparations in order to drive the English out of the country; and with this object was urging Zemaun Shah to proceed with his invasion in the North, while at the same time he himself was gaining all the assistance he could from the French, with whom at that time we were at war in Europe. However, Tippoo was killed at the fall of Seringapatam on the $4^{\text {th }}$ May, 1798.

Notwithstanding Tippoo's death, it was considered necessary that we should protect our- 
selves fromanyattack that Zemaun Shah might deliver, supported by the French, who it was supposed intended marching into India through Persia and Afghanistan. In 1 799, therefore, for the purpose of strengthening our hands, Captain Malcolm was sent by Lord Wellesley upon a mission to Persia, in order to form an alliance with that country. This if satisfactorily arranged would, owing to our command of the sea, place us in a position to land troops when required in Persian territory.

A treaty was concluded between England and Persia by which the Persian king promised to advance into Afghanistan, should the Afghans attempt an invasion of India, and an allied army of England and Persia was to resist the French, should they attempt an invasion from Europe; also all French agents were to be excluded from Persia. However, the Afghan invasion came to nothing, Zemaun Shah was blinded by his subjects, and became a pensioner of the British Government, and Shah Mahmoud became the ruler of Afghanistan until deposed by Shah Soojah.

In 1808 another mission was despatched to Persia, as it was then considered that the relations of that Court with France were of a dangerous character to ourselves. Persia 
afraid of the designs of Russia, thought France was the only power who could interpose effectually in her favour; but even then Napoleon's career was closing in, for the French were being rapidly driven out of the Peninsula by Wellington.

In $1809 \mathrm{Mr}$. Elphinstone was sent upon a mission to Shah Soojah, the King of Afghanistan, and satisfactorily concluded a treaty with him. Mr. Elphinstone describes the king as magnificently attired, covered with jewels and precious stones, while everything around him appeared luxurious in the extreme, his tents were decorated with silk, and silver bells, and a portable house of two stories, that could be set up by a hundred men in an hour, accompanied him on his march. But the state appeared to $\mathrm{Mr}$. Elphinstone to have little vitality in it, and to be but a great kingdom going to decay. He describes the Afghans as treacherous, and ready to plunder their guests as soon as they had left their houses. He describes an attack upon the house tenanted by the Embassy at Peshawur, which was with difficulty suppressed, and which somewhat resembles the attack upon the Embassy at Cabul in I879, and the attack upon Burnes' house in 
I $84 \mathrm{I}$; only that fortunately in this first attack the sedition was checked before any damage had occurred. Shortly after Mr. Elphinstone's arrival at Peshawur, and his gracious reception there, Shah Soojah marched against Shah Mahmoud, who had rebelled against him, captured Candahar, and advanced upon Cabul. In this expedition against his rebellious subject Shah Soojah was defeated, and fled as a refugee to the Court of Runjeet Singh, the Sikh king, who entertained him for a short time, but, taking advantage of his misfortunes, extorted from him much treasure, as well as the celebrated Koh-i-noor diamond, which is now in our possession among the regalia, having been obtained by us when we took the Punjab. Shah Soojah, after a short time, escaped from Runjeet Singh, and became a British pensioner.

Afghanistan was now torn by internal dissension, no ties of blood or honour were of sufficient strength to prevent treachery, until after frequent plots, and much fighting, Dost Mahomed, the most capable of the Afghan chiefs, attained supreme command in 1826 . Dost Mahomed was brother of Fati Khan, chief of the Barukzies, who, after having raised Mahmoud a second time to the throne by 
defeating Shah Soojah, and after having brought the country into good order, and governed it with great force and power for Shah Mahmoud, had been treacherously seized and subsequently murdered by the order of the very man for whom he had done such good service, and whom he had raised to be king.

While the brothers of Fathi Khan were rebelling against Mahmoud Shah, and while Dost Mahomed was obtaining for himself the chief command in Afghanistan, Russia was pushing on her frontier at the expense of Persia, and although we were bound by Malcolm's treaty to assist Persia, yet we sent her neither men nor money as we had agreed, maintaining, rightly or wrongly, that the war was commenced by Persian aggression, although no doubt the provocation came from Russia. Finally we paid a sum of money to obtain the erasure from the treaty of the articles concerning the help we were to give.

This was certainly doubtful policy on our part, and the fruits of it were soon shown, for Russia having obtained, by her various successes against Persia, considerable hold on that country; her agents, with the object of 
thwarting England, commenced instigating the Persian monarch to attack Afghanistan in order to obtain possession of Herat and Candahar, which places had formerly belonged to the Persian Crown.

In 1835 Lord Auckland was appointed Governor-General of India by the Whig Ministry, and received a letter of congratulation from Dost Mahomed, to which he replied in a friendly manner, and the next year sent up Mr. Burnes, afterwards Sir Alexander Burnes, on a commercial mission to Cabul, where he was favourably received by Dost Mahomed, and his commercial mission changed into a political one.

Shortly after Burnes' arrival in Cabul, a Russian agent arrived there, bearing purely commercial letters to the Ameer from the Emperor of Russia. This agent, however, was received with but little attention by the Ameer, as Dost Mahomed was aware of the rivalry between England and Russia, and preferred to have the former for his ally.

The chief object that the Ameer had in view in allying himself with England was the recovery of Herat and Peshawur, both of which places had been separated from his crown during the recent troubles in Afghan- 
istan; for while Dost Mahomed had been obtaining the chief power in his distracted country, Runjeet Singh had by gradual encroachments pushed his frontier northwards, and finally at Noushera had defeated the Afghans, and thereupon claimed Peshawur, and in fact, had nominated and installed an Afghan governor in that place, who paid him tribute; and about the same time, Kamran, the son of Mahmoud, the late King of Afghanistan, had established himself in an independent position at Herat. Hence it was that Dost Mahomed applied to us for assistance, thinking that we might induce Runjeet Singh to give back Peshawur.

Mr. Burnes himself was inclined to the policy of a strong Afghanistan, under a ruler friendly to ourselves, and thought that Runjeet Singh might easily be induced by us to give back Peshawur to Dost Mahomed, to be held by him as tributary to Lahore, and this would have greatly strengthened the Ameer's position. But the Governor-General, Lord Auckland, wrote to $\mathrm{Mr}$. Burnes instructions entirely contrary to this plan, and Mr. Burnes was compelled, against his own inclinations and opinion, to let the Ameer see that Lord Auckland discountenanced all idea of his 
recovering Peshawur. Now, it was important for Dost Mahomed to have Peshawur added to his kingdom, as his brother, Sultan Mahomet, his declared enemy, was striving to obtain full power over that country, and thus situated in so important a position, he formed a standing menace to the Ameer's Government.

Unable to attain the assistance that he wished for in one quarter, the Ameer naturally turned to the other quarter. Burnes had started on his mission with miserable toys instead of the handsome presents of the previous expedition under Elphinstone; he had been directed to ask much, and to give little, and as Dost Mahomed clearly put the matter, "we proposed to assist him, but our assistance really was hastening his ruin."

It was not unnatural, therefore, that our embassy should fall into disrepute; as the influence of $\mathrm{Mr}$. Burnes began to fail, that of the Russian agent rose; for, although the Ameer had been kind and straightforward, what was to be expected but failure under the circumstances; in Burnes' own words, "Lord Auckland must have been the most sanguine of men had he expected any other result." 
The Ameer therefore entered into negotiations with the Russian agent, which resulted in his receiving from the Russians large promises of help and assistance, and decided help in the shape of an attack upon Herat by the Shah of Persia, at Russia's instigation, and assisted by Russian officers.

The Whig Government now thought it necessary to make a counter move against Russia, and urged Lord Auckland to adopt vigorous measures in order to counteract Russian aggression, both in Persia and Afghanistan. Lord Auckland having got himself into this unfortunate position by his hesitating policy, afraid to fix himself with the slightest liability, now began toconsider how he should proceed, and finally came to the conclusion that there were three courses open to him. Ist. Simply to maintain the line of the Indus, and leave Afghanistan to its fate.

2nd. To assist the chiefs of Afghanistan.

3 rd. To assist Runjeet Singh and Shah Soojah to march to Afghanistan, and take the country.

Lord Auckland chose the last, and despatched Mr. Macnaghten to the court of Runjeet Singh for the purpose of making a triplicate treaty with him and Shah Soojah, 
for the conquest of Afghanistan, and for placing Shah Soojah on the throne. We therefore came to be acting against Dost Mahomed, instead of with him, and thereby we found ourselves in the position of setting up a weak king who had been deposed by his subjects, and been living in exile for years, against Dost Mahomed, who was recognized as the most capable chief in the country, one who had always wished to be our friend, who preferred our friendship to that of Russia, and who had always been willing to be guided by our councils when they were not opposed to his own interest, and who, further, had never been guilty of any treachery towards us, and this is saying a great deal for an Afghan.

In 1838 , therefore, according to the new policy, a large British force was collected on the northern frontier of India, in order to march via Candahar to attack the southwestern portion of Afghanistan; with these Shah Soojah and whatever troops he could collect, was to march, while Captain Wade, and the son of Shah Soojah, were to advance with the Sikh troops, our allies, through the Khyber pass.

Opinions, both in England and India, were 
loudly raised against this war, which was one, undertaken against a chief who had done us no harm, except in so far as listening to Russian advice, because we had declined to assist him. Loud complaints were also raised on account of the avowed object of the expedition being to prevent Persia from taking Herat, and, this being the case, it seemed somewhat inconsistent that we should make war on the ruler of Afghanistan, in order to prevent the ruler of Persia from taking a city which at that time was independent of both kingdoms, and which was even then making a vigorous defence against the army of the Shah. In this defence the people of Herat were assisted by a young Englishman, Eldred Pottinger, who, by his energy, pluck, and skill, so baffled the enemy that, after spending many months before the walls, with considerableloss of life and treasure, the Shah of Persia was obliged to raise the siege, and retire from the contest ; now, as this took place before Lord Auckland's manifesto of the war was published, one of the objects for which we proposed to go to war was already accomplished. After the failure of the expedition, when these things came to be criticized, and it was found out that 
Burnes' advice would, had it been followed, have given us all we desired, without any war, ugly rumours got afloat as to the manner in which his despatches had been tampered with, before being presented to the country by the Government.

However, the war commenced, and various troubles occurred in crossing the independent country of the Punjab and Scinde, which lay between our frontier of those days and that of Afghanistan, for not yet was thought of the celebrated despatch which surpassed Cæsar's veni, vidi, visi in brevity, namely "Peccavi," "I have sinned," when the conquest of Scinde was completed by Napier. The commands in the west were entrusted to Sir Willoughby Cotton and Sir John Keane; the former marched by Ferozepoor and Shikarpoor to the Bolan Pass, which he traversed in six days, after losing many baggage animals and much baggage, and Sir John Keane, with the Bombay division and the Shah's army, having made their way through Scinde after overawing the Ameers of that country, followed Sir Willoughby Cotton up the Bolan Pass to Quetta, where Sir John Keane took command of the whole force.

In April, 1839, Shah Soojah entered 
Candahar. Up to this time the army had suffered in physique from want of provisions, and had lost large numbers of its transport animals and baggage, but had met with no opposition from the enemy.

After a long halt at Candahar to collect supplies, Sir John Keane advanced upon Ghuzni, which he took by assault. The Cabul Gate was blown up, whereupon Colonel Dennie, at the head of the stormers, rushed in, and shortly afterwards three cheers announced that they had established themselves within the walls. Colonel Sale followed Colonel Dennie, and after much severe fighting we obtained possession of the place. The fall of Ghuzni astonished the Afghans. Dost Mahomed Khan fled across the frontier of Afghanistan, and his guns were found in position, and captured. On the 6 th of August, I 839 , the army reached Cabul, and the next day the king entered the city in state. Shah Soojah was now restored to his kingdom, but it was found that he was unable to govern it without British assistance. While these events were taking place in the west, Captain, now Colonel Wade, with the Sikhs, had pushed up the Khyber, taken Ali Musjid after a 
short resistance, and through Dakka and Jellalabad, reached Cabul. Our Sikh allies had proved themselves but very weak-hearted in the cause, and no dependence was therefore to be placed upon them.

Much annoyance was as usual caused by the Khyberees until they were bought off.

In the south, Khelat was captured by assault as a punishment for the frequent depredations committed by the Beloochees.

The danger of Russia in Afghanistan had, it appears, been greatly magnified in the minds of our statesmen, by an expedition she had undertaken in 1840 against the Khan of Khiva, in order to chastise him for his slavedealing propensities; Russia affirming that the Khan had taken several Russian subjects and kept them in slavery. It was supposed that this expedition would push on against the Shah of Bokhara. But the force was attacked by famine, and unable to advance owing to the cold and the rugged country through which it had to pass. On the failure of this expedition all fear was removed for the time from the minds of our statesmen concerning Russia's counter-move in Asia. This expedition and its failure is somewhat similar to Russia's expedition against the 
Tekke Turkomans which failed in 1879 ; the expedition that they have lately organized on a much larger scale under General Skobeleff, the Balkan hero, has been fairly successful.

But to return, Shah Soojah being established at Cabul, and the whole country being apparently quiet, it appeared that now was the time for us to retire and leave the king to manage his kingdom; it is true he was not very firmly seated on the throne, but few Afghan kings ever are. Macnaghten, our political officer, was of opinion that the country was settling down, and it was obvious that we could not keep an army perpetually in Afghanistan, and further, it could with reason be urged that the Afghan king, left with a few faithful subjects, would have a stronger hold on the mass of his people, and therefore be a stronger ruler, than if he were supported by foreign bayonets. The opportunity of thus leaving the country was, however, missed, and soon it became clear that all was not going so well as Macnaghten thought, for signs of ferment appeared in many directions ; near Candahar the Ghilzies and Beloochees were again giving trouble, and had to be chastised, while in the north a detachment 
was attacked and lost several men, and in Cabul itself there were signs of disturbance. Major Todd also, our envoy at Herat, had been obliged to retire from that place overwhelmed with insults; and the Duranis also were giving us trouble. Our attacks on these different tribes, though generally successful, were not sufficiently carried out, being made by small parties of troops sufficient to irritate without crushing our treacherous enemies.

Sir Willoughby Cotton was now succeeded by General Elphinstone, an old officer who had served his country bravely and well, and who, although he obtained the respect of every one as a brave old gentleman, was not at all strong, a martyr to the gout, and not by any means the right man for Lord Auckland to have pitched upon for this special service, a service that was trying to the full the powerful brain of Macnaghten.

The troops at Cabul were quartered in what were called the cantonments, which formed a long parallelogram, the whole being surrounded by a ditch and mud wall; the ramparts, however, were so weak that in many places they could be ridden over, and the position was such that it could be swept by fire from the hills and forts on all sides; 
added to all this, the troops had been encouraged to have their wives and children with them, as it was considered that the occupation of Afghanistan would be a question of time. The expense of this continued occupation of the country began to tell heavily on the exchequer of India, and Macnaghten was ordered to economize; he began by cutting down the pensions and subsidies of the Afghan chiefs; this touched them in a point where they were very sensitive; accordingly secret meetings were held by the discontented chiefs, and finally the eastern Ghilzies broke into rebellion and held Khoord Cabul pass against us. Sir Robert Sale was sent against them, and after some difficulty cleared the pass and marched on towards Jellalabad, unfortunately not taking the opportunity of inflicting a severe blow on this restless tribe.

On November Ist, I 84 I, several chiefs met in secret, and the next day there was a commotion in the city of Cabul; Sir Alexander Burnes' house was attacked, and he and nearly all in it were massacred. The Shah sent out some troops from the Balla Hissar, but they were unable to quell the disturbance, and finally retired before the insurgents. 
The British army remained inactive all day, Brigadier Shelton only assisting to carry off the guns, which the Shah's men would otherwise have lost.

This insurrection, there is no doubt, was but small and unprepared in its first outbreak, and any action of decision would have crushed it ; and by crushing it would have strengthened our position, while showing us how precarious that position was.

The next day the insurgents, animated by their success, gathered in far larger force, but still nothing was done, till, increasing in boldness, they attacked parties of our troops and our commissariat fort, containing the clothing and food for the army, which by a gross blunder had been placed at a distance from the cantonments. The small detachment in charge of the fort held out for many hours, until, finding that the Afghans were undermining one of the towers, and that no reinforcements came to their repeated calls, they evacuated the fort, leaving there the food of the entire force; General Elphinstone having failed to send out a sufficient force, either to drive off the Afghans or reinforce the place. The position of Elphinstone's army now became very critical, for it was obvious that C 2 
they could not collect supplies enough to keep them from famine, not having sufficient troops for that purpose to spare from the arduous duty of guarding the cantonments. Further, the general and his second in command, Brigadier Shelton, could not agree, and the general was so careful of the lives of his soldiers that he permitted them to be annoyed night and day by the Afghans, rather than make an attack which he thought dangerous against the enemy's position. So things went on getting worse and worse, the men and officers burning to attack the enemy, but the general uncertain and afraid to give the necessary orders. It was now proposed, as the winter was coming on, either to retreat, or to move to the Balla Hissar, where the men would be in better quarters, would not be harassed by perpetual attacks, and might periodically sally out and capture provisions. But this was overruled, chiefly on account of the difficulty of moving the wounded, though the distance was only two miles.

Several small fights now took place which showed the want of capacity of Brigadier Shelton, into whose hands the command had virtually fallen, Elphinstone being too ill to take the management of affairs, although he 
never actually resigned the command. These fights also showed the demoralization of the troops, both native and European, both of whom on different occasions refused to follow their officers, and fled before the Afghans.

Macnaghten in this trying conjunction attempted to make a treaty with the Afghan chiefs, but was offered the most humiliating conditions, the terms of which were, that if the force yielded up their arms and guns, their lives would be spared. These conditions were of course refused with scorn, but a treaty was drawn up for the retirement of the forces. The treaty, however, though observed on our side, was mere waste paper on the side of the Afghans. Finally Macnaghten was invited to a conference outside the cantonment, where he and one of the officers with him were basely murdered in sight of his escort, two other officers being carried off prisoners. Notwithstanding all this, our troops were never moved out to the attack that day. Another treaty was now drawn up, by which the guns were given up to the enemy. The hope had long since died out of any assistance from Candahar or Jellalabad; General Nott at the former place was unable to advance, and Sir Robert Sale was by this 
time holding out with his small force at Jellalabad, himself hardly pressed by the enemy. In all this history of treachery and incompetence it is a relief to turn to the account of General Sale's force; whether he was right in not attempting to assist Elphinstone, is a matter which can always bear discussion; doubtless, had he been able to march on Cabul he might have saved the force there, for his vigorous counsels would alone have been sufficient to turn the odds against the Afghans. But on hearing of the Cabul troubles he held a council of war, which decided that it was not advisable for him to advance; he therefore broke up his camp at Gundamuck, and retired to Jellalabad, which he made himself master of, and proceeded to fortify. In thus holding Jellalabad, Sale had no easy task; the fortifications of the place were in lamentable order, and one part of them was commanded by some rocky hills from whence the enemy kept up a perpetual and accurate fire upon the defenders, this they were well able to do as their longbarrelled guns were superior to our muskets, carrying further, and being more accurate.

The supply of food was very short in the city, and to add to the trouble of the garrison an earthquake shook down a large part of the 
fortification walls, which they had built up with much care and danger; yet such was the determination and energy of the little force, that the Afghans, who were bold enough in attacking Elphinstone's army, got very shy of coming to interfere with Sale, for whenever they were bold enough to show a determined front, Sale led out his men and defeated them. The health of Sale's men was splendid, for although they were living on half rations, without any spirits, an officer who was one of the garrison assured the author that they had scarcely a man in hospital. On the 6 th of January a letter was received at Jellalabad from Elphinstone ordering the evacuation of the city, but neither Sale, nor any of the officers there, were inclined to throw themselves on the mercy of the Afghans, and therefore they refused to stir until they received further orders. They little thought that the next communication they would receive would come from Dr. Bryden, the sole survivor of the massacre of the Cabul army.

On the 6 th of January, 1842, Elphinstone evacuated his cantonments, relying on a treaty which had been arranged with Akbar Khan, and other chiefs. By this treaty the force 
was to be escorted through the passes by a body-guard of Afghans.

Thus on the morning of the 6th of January the Cabul army started; the escort of Afghans, however, did not arrive; the baggage was not ready; the bridge over the Cabul river was not yet sufficiently repaired; instead of getting off by daylight, it was noon before the bridge was ready for the troops; already the enemy were swarming into the cantonments before the rear guard left them; it was six in the evening when the rear guard passed out. The force halted for the night six miles from the city, the road was strewn already with dead and dying, the cold was intense; the snow lay thick on the ground; soldiers, camp followers, and cattle were mixed up in terrible confusion. When morning broke, the camp followers struggled on, discipline was gone; the enemy pressed on the rear of the force, seizing and slaying all they could.

The rest is soon told, Akbar Khan and his Afghan horsemen came offering food and escort, but no food was brought, while the troops were attacked on all sides by the murderous Afghans. The only hope of safety for the force lay in the rapidity with 
which they could march through the passes, every moment wasted, increasing the number and boldness of their assailants; yet Elphinstone, incapable here as ever, refused to push on; thus two more fearful nights were spent. Akbar Khan now took the women and children under his protection, and another halt was called on the 11 th, five days after leaving Cabul; here they remained until the evening of the 12 th, during which time General Elphinstone, Brigadier Shelton, and other officers were detained by Akbar Khan as hostages ; the troops expecting the food and assistance that Akbar Khan promised, but neither were forthcoming, so the remainder of the force, reduced to about 150 fighting-men and some camp followers, pushed on to Jugdulluck. Here they found the pass, which is very narrow, barricaded with rocks and branches of trees ; the small body of Europeans, however, fought with desperate valour, and here the artillery, under Captain Nicholl, displayed that unshrinking courage and determination, which won for them the awe and admiration of the Afghans. Many fell at the barrier, and only seventy reached Gundamuck, (the place where the treaty was concluded in 1879 , between Major Cavagnari and Yakoob Khan.) 
At Gundamuck, these were attacked by the peasants, and only six escaped. A few miles farther on, these six were offered food, and while they were eating it, the enemy attacked them; one only, Dr. Bryden, escaped, and was brought in half dead to Jellalabad on January I 3 th, I 842 , with the exception of the prisoners and some natives who deserted, the sole survivor of a force of 4,500 fighting-men and 12,000 camp followers. When the news reached India, people were overwhelmed with the magnitude of the disaster.

Lord Auckland's mental faculties were, for the time, obscured by this crushing blow to his policy; the Commander-in-Chief thought it unnecessary to send any more troops into Afghanistan, considering it wise to keep all the available troops to counteract any attempt at rebellion in India; however, wiser judgment prevailed, and after some delay, General Pollock was appointed to the command of a force to start for Peshawur. Meanwhile a force under Brigadier Wild had advanced with our Sikh allies up the Khyber, but the expedition had been a failure, the advanced portion of the force had indeed taken Ali Musjid, but by mistake only a quarter of the baggage animals had been sent with them, and conse- 
quently they found themselves in the fort without food, or possibility of getting it ; and when Brigadier Wild advanced with the main force, the Sikhs refused to attack the enemy ; the fears of the Sikhs contaminated our native troops; nothing therefore remained to be done but to retire to Jumrood.

Shortly afterwards the Ali Musjid garrison were forced to return by want of food, and the place was therefore abandoned.

General Pollock arrived at Peshawur in February, and remained till April recruiting the health and spirits of his troops, for they were in a state of almost open mutiny. Transport was then, as at the present time, one of the greatest difficulties to be overcome, camels were scarce, and the camel-drivers deserted in great numbers. However, General Pollock overcame all these difficulties, and on the $5^{\text {th }}$ of April, 1842 , advanced from Jumrood. The Khyberees had thrown up a barricade across the mouth of the pass, but they were not prepared for Pollock's mode of attack, he sent strong flanking parties up the hills on either side of the pass, and the troops soon showed that when properly led, they were able to beat the Khyberees on their native hills, for the enemy 
fled on all sides, and the barricade was turned and destroyed. General Pollock now marched on through the pass, and, without encountering much further opposition, relieved Jellalabad.

On the $5^{\text {th }}$ of April Shah Soojah was murdered by treachery in Cabul, and thus ended the rule to support which we had spent so much blood and treasure. r

While these events had been taking place at Cabul, and on the east of the seat of war, General Nott, at Candahar, in the south-west, had been much pressed by the enemy; a relieving force which he had sent out to Cabul had failed to display the requisite energy, and had consequently returned without reaching that place, where its assistance might have proved invaluable. The enemy, emboldened by the state of affairs in Cabul, had attacked Candahar with great determination, but were repulsed; still, although they had failed in their attack on Candahar, they had taken Ghuzni, and destroyed a party convoying provisions. General England had been directed to march from Quetta with ammunition and treasure to relieve Candahar; but he advanced without much spirit, and was unable to rout the enemy opposed to him ; thus stopped in his attempt to reach Canda- 
har, he waited until he received from General Nott decisive orders to advance, and until that general had sent out some of his own men to meet him, these crowned the heights of the Khojak pass, and reported all clear for General England's advance, not a little to the envy of that general's troops, who ought to have done the work themselves.

But to return to General Pollock, it was not till September that he could obtain permission from the Governor-General, Lord Ellenborough, to advance against Cabul, though both he and Nott were burning to do so.

When Pollock did advance, he found the enemy posted at Jugdulluck, the scene of the massacre. "Here," says one writer, "the skeletons lay so thick that they had to be cleared away to allow the guns to pass. The savage grandeur of the scene rendered it a fitting place for the deed of blood which had been enacted under its horrid shade, never yet pierced in some places by sunlight. The road was strewn for two miles with moulder. ing skeletons like a charnel house."

Now the enemy found they had to deal with other men, under other leaders, for, putting their whole energy into the work, the 
British troops scaled the heights and steep ascents, and defeated the enemy in their strongholds on all sides. After one more severe fight with Akbar Khan, and all the force he could collect, the enemy were beaten, and driven from their mountains, and the force marched quietly into Cabul.

Nott, on his side, started from Candahar on the 7 th of August, and, after fighting several small battles with the enemy, he captured Ghuzni, where Palmer and his garrison had been destroyed. From Ghuzni General Nott brought away, by command of Lord Ellenborough, the gates of Somnauth, which formed the subject of the celebrated "Proclamation of the Gates," as it was called. This proclamation, issued by Lord Ellenborough, brought upon him endless ridicule, and was indeed at first considered to be a satire of his enemies, in imitation of Napoleon's address from the Pyramids; the Duke of Wellington called it "The Song of Triumph ;" it ran as follows:- "My brothers and my friends." "Our victorious army bears the gates of the temple of Somnauth in triumph from Afghanistan, and the despoiled tomb of Sultan Mahomed looks upon the ruins of Ghuzni," "The insult of 800 years is at last avenged." 
"The gates of the temple of Somnauth, so long the memorial of your humiliation, are become the proudest record of your national glory ; the proof of your superiority in arms over the nations beyond the Indus." "To you, princes and chiefs of Sirhind, of Rajwarra, of Malwa, and of Guzerat, I shall commit this glorious trophy of successful war." "You will yourselves, with all honour, transmit the gates of sandal-wood through your respective territories to the restored temple of Somnauth." "The chiefs of Sirhind shall be informed at what time our victorious army will first deliver the gates of the temple into their guardianship at the foot of the bridge of the Sutlej."

This proclamation, put forth with so much flourishing of trumpets and ado, was really an insult to those whom it professed to praise, it was an insult to the Mohammedans under our rule, for their power was gone, it was also an insult to the Hindoos, for their temple of Somnauth was in ruins. These celebrated gates, which are believed to be imitations of the original gates, are now lying neglected and worm-eaten, in the back part of a small museum at Agra.

But toreturn, General Nott, having captured 
Ghuzni and defeated Sultan Jan, pushed on to Cabul, where he arrived on the 17 th of September, and met Pollock.

The English prisoners, (amongst whom were Brigadier Shelton and Lady Sale,) who had been captured at the time of the massacre, were brought, or found their own way, to General Pollock's camp. General Elphinstone had died during his captivity.

It was not now considered necessary to take any further steps; the bazaar in Cabul was destroyed, and on the 12 th of October Pollock and Nott turned their faces southwards, and began their march into India by the Khyber route. The Afghans in captivity were sent back, and the GovernorGeneral received the troops at Ferozepoor. Thus ended the Afghan war of $1838-42$.

The reason of the failure which we experienced was clearly the wrong and mistaken policy upon which the war had been commenced. That which was begun by a blunder of policy, was consummated by great military incapacity and supineness. The war being over, we withdrew our forces into India, leaving the son of Shah Soojah, Fathi Jung, who had escaped from Cabul when his father was murdered, 
as king of the country, a position that he was unable to maintain long, being very shortly afterwards assassinated.

In 1842 Dost Mahomed, the ruler whom we had deposed, and who had been living at our expense in India, returned to Cabul and resumed his former position as king of the country, still bearing ill-will towards us, which he showed on several occasions, notably during the Sikh war, when he sent a body of his horsemen to fight for the Sikhs, and he himself marched an army through the Khyber to Peshawur to assist our enemies. However, the occupation of the Punjab forced upon Dost Mahomed the necessity of being on friendly terms with his powerful neighbour; he therefore concluded a friendly treaty with us in 1854 , hoping thereby that our power would be used to prevent the intrigues of Persia against his kingdom. This hope was shortly after realized, for in 1856 we declared war against Persia, an event which was greatly to the advantage of Dost Mahomed, as it prevented Persian encroachments upon his territory. This war lasted but a short time, for early in 1857 an agreement was signed between England and Persia, by which the latter renounced all 
claims over Herat and Afghanistan. Herat, however, still remained independent of Afghanistan, until I863, when Dost Mahomed attacked and took the town, thus uniting the whole kingdom, including Candahar and Afghan Turkestan, under his rule. This was almost the last act of the Ameer's life, for a few days after taking Herat he died. By his will he directed that Shere Ali, one of his sons, should succeed him as Ameer of Afghanistan.

The new Ameer immediately wrote to the Governor-General of India, Lord Elgin, in a friendly tone, asking that his succession might be acknowledged. Lord Elgin, however, as the commencement of the Liberal policy of "masterly inactivity" neglected to answer the letter, a neglect which cannot but be deeply regretted, as Shere Ali was at all events the de facto ruler of the country, and even had he been beaten by any other rival for the throne, it would have been time enough to acknowledge that rival as soon as he was really ruler of the country. When six months later a cold acknowledgment of the letter was given by Sir William Denison, and when a request that the Ameer made for 6000 muskets had been refused by Lord 
Lawrence, the Ameer concluded that the disposition of England towards him was not that of a friend; particularly as, when later on, two of his brothers revolted against him, each of them was told by the Government that he would be acknowledged for that part of the country which he brought under his power.

However, after various changes in fortune, in 1869 Shere Ali finally defeated his two brothers Afzool and Azim, together with Afzool's son, Abdurrahman. This Abdurrahman is the man into whose hands we have now given Afghanistan.

We now come down to the origin of the present war in Afghanistan. In order to understand the origin of this war it is necessary to take note of the movements of Russia. It was the fear of an attack on India from Europe, through Afghanistan, that led to our proceedings in Persia previous to the last Afghan war, and to that war itself. These fears have increased in proportion as Russia has steadily pushed on her frontier nearer and nearer to India.

In 1856 Russia attacked the tribes who for so long had withstood her rule in the Caucasus. With the aid of a very large force 
she managed to subdue these rough mountaineers, and has since kept them subservient to her rule by severe regulations, and strong military garrisons. This accomplished, Russia then pushed up the Jaxartes River, and in 1863 attacked the Khan of Khokand, and shortly after captured Turkestan, a town belonging to the Ameer of Bokhara.

These movements of Russia caused the English statesmen then in power, to make representations to the Russian Government, which representations were replied to by Prince Gortschakoff, who stated that the advance was necessitated by the nature of the people with whom Russia had been thrown in contact, but that now she had reached a solid and compact country, and therefore the Russian frontier would be there fixed.

Sir Henry Rawlinson shows that this communication to the English Government did not rest on any solid foundation; written in November, 1864, it was seen to be false in June, 1865 , for by that time the Russians had attacked the Ameer of Bokhara, and conquered Tashkend. So again in September, 1865 , Russia declared that she had no wish to add to her dominions, yet in 1866 she captured Khojend, and obtained sovereignty 
over the whole of Khokand; shortly afterwards Samarcand was taken, and the Ameer of Bokhara was obliged to admit Russian supremacy.

It was now proposed by Lord Clarendon that Afghanistan should be a neutral zone between the English and Russian frontiers, and to this Prince Gortschakoff agreed, declaring that the Czar "looks upon Afghanistan as completely outside the sphere within which Russia may be called upon to exercise her influence."

While Russia was making these soothing speeches, she was quietly preparing for an expedition against Khiva, at the same time denying repeatedly that such an expedition was in prospect. In June, 1873, however, Khiva was taken, and the whole of its territory, on the right bank of the Oxus, annexed.

These rapid advances of Russia towards the Afghan frontier had the effect of disquieting Shere Ali; he saw that with a powerful state on one side of Afghanistan, and another powerful state advancing on the other side, it was advisable for him to arrange for the support of one neighbour against the attacks of the other, and with this object he 
wrote to Lord Lawrence in I868, asking for an interview at Peshawur. But, owing to rebellion in his dominions, this interview was postponed until 1869, when Lord Mayo, having been made Viceroy, invited the Ameer to a conference at Umballa. However, the Conservative Government who appointed Lord Mayo, having been succeeded by the Liberals, the Viceroy found his hands tied; for the Liberal Government, acting upon Lord Lawrence's policy, were disinclined to make any promises, or in any way to bind this country to a decided policy in respect of Afghanistan, or to undertake any responsibilities in the matter.

During this conference, the Ameer frequently assured the Government that if we would acknowledge and support him, and the heir he would point out, then there was nothing he would not accede to; he was open to any propositions for securing his northern boundary, for facilitating trade with India, and for receiving English officers in some of the towns of Afghanistan, not Cabul. He frequently asserted that our not acknowledging him as Ameer, after the death of Dost Mahomed, had been the cause of all the troubles which he had encountered. 
In this conference, however, Shere Ali did not obtain the offensive and defensive alliance which he looked for, but instead of it was, obliged to be content with vague promises of support ; and being dissatisfied, he was naturally not inclined to agree to what we desired, namely, that British officers should be placed in certain towns of Afghanistan to inform their government of what was going on in the country; the result of the conference, therefore, was not altogether satisfactory.

So matters went on until the capture of Khiva by the Russians in 1873 . Alarmed at this near approach of Russia, Shere Ali sent an envoy to Lord Northbrook, the then Viceroy, stating his apprehensions, and asking for a close alliance, arms, and money. But the Liberal Government treated the matter very lightly, stating that Afghanistan was beyond Russian influence, and that aggression from that quarter was not anticipated, but that should the Ameer be attacked from without, material aid would be given to him if he abstained from aggression and followed the advice of the British Government.

The origin of this the Simla Conference 
seems curious. Lord Cranbrook states, that the Ameer desired the conference in order to obtain assurances of protection against Russia, who was pushing on towards his frontier. But it is asserted by the Liberal side, that it was from the British that the proposal for the interview came, and that Lord Northbrook himself proposed it.

Now at this time Lord Northbrook was aware that the Ameer was in a state of considerable irritation with England, principally on account of the Seistan award, and that he was alarmed at the approach of Russia ; the policy, therefore, of the Viceroy should have been to smooth the difficulties and allay the causes of irritation which were disturbing the friendship between the Ameer and ourselves; for this purpose what specific do we find the viceroy had at his disposition? As to Russian advances, he was prepared to say that the communications which had passed between Russia and England, led the latter to the decided conclusion that Russia had no views adverse to Afghanistan. Such explanations contained nothing of solid value to the Ameer of Afghanistan, and beyond this he obtained nothing more than that which he had received already from Lord Mayo, and 
it is clear from his reported opinions, that he did not coincide with the British Government in its belief of the value of the Russian explanations, and in this he was without doubt right; for recently published papers have conclusively proved that Russia considered Afghanistan very much within the sphere of her operations as soon as she desired to affect the policy of England, for it is clear that the object of sending General Stolietoff to Cabul in 1878 , was to make the Ameer either a friend or a foe to Russia.

Under these circumstances, then, surely Lord Northbrook was scarcely wise in proposing the conference, as it has been asserted, for if the Ameer was satisfied with his position, what was the use of officious diplomacy which was contrary to the inactivity policy; and it was scarcely necessary to have a special conference in order to find out if the Ameer was willing to receive British officers to examine his frontier, for this was the object sought to be obtained by us in the conference. There is no doubt as to the result of the conference; it was, that Noor Mahomed, the Ameer's envoy, went back much more dissatisfied than he had been previous to the conference, and that the 
Ameer grew colder to us after his return. For it had been made perfectly clear to Noor Mahomed that we desired to have British agents in Afghanistan, and also to hold ourselves free from any but very vague promises of assistance to the Ameer.

The Ameer stated at this time, through his agent, that he foresaw that the Russians would advance and demand some portion of his territory, which for the sake of peace we should agree to their taking. And in saying this he was only echoing the common opinion in Europe at the time. Holding this opinion, the Ameer came to look upon us almost with contempt, for he considered we should never be a valuable ally to him, as he held that, for the sake of peace, we should give way to anything so long as it did not actually affect ourselves; this was the key-note of all his subsequent proceedings, hence the exertions he made to form a powerful army, and the large expenditure which he sanctioned for the purpose of manufacturing and collecting war material, and building fortifications at Sherpur. No doubt he remembered the destruction of the British army in the $18{ }_{3} 8-42$ war, and he considered that, with the large force he was gathering round him, he would be able to act 
independently of England, and even to hold his own against her in war. Hence it was that his language became "anything but satisfactory" after the conference, and his actions became more and more unfriendly, until the final insult to our Envoy in the Khyber Pass in 1878 .

Thus threatened by Russian advances, doubtful of the assistance he would receive from England, and thinking himself able with impunity to defy her, he naturally made his terms with Russia.

This view is in conformity with the Ameer's other actions, with his refusal to allow two English officers, who had been travelling, to pass through his country on their way to India ; with the assertion of Noor Mahomed at the Peshawur conference in 1877 , that, "this is the last opportunity for settlement, and God only knows the future;" and finally with his reception of the Russian Embassy with distinction, and his refusal to allow our Embassy to advance.

Such, then, was the result of the masterly inactivity policy, a policy which degraded us in the eyes of an Oriental king, and consequently also in the eyes of our own native subjects in India. A policy which, whatever it 
may be called, cannot be considered kind to the Ameer, as it led him into a war which destroyed his power; or wise for ourselves, as it not only lost us great influence, but it cost us the large expense of the late Afghan war; a war which viewed by the light of recent events and of the correspondence between the Ameer and the Russians, cannot but be considered under the circumstances wise and politic, however much it may be regretted.

But to return, not only was the Ameer disappointed by the answers he received to his appeal for a friendly alliance in this conference, but he was irritated by the decision given by General Goldsmith in the Seistan boundary question, by which the Ameer maintained that his territory was reduced, and that the boundary defined was such as was likely to occasion him annoyance by generating ill-will between himself and his neighbours, as well as causing him considerable expense. The Ameer was also annoyed at the government refusing to recognize his heir, at Lord Northbrook's mediation for Yakoob Khan, at our despatch of an Embassy to one of his feudatories direct, and not through him, as Suzerain, and finally at our occupation of Quetta. There were also several other 
minor complaints, such as articles in the newspapers, and so forth.

As to these grievances, it may be briefly stated that no doubt the Ameer had been carelessly treated in one or more points, but there was no real cause in the list of his complaints for the course he took of turning to Russia, particularly as he was aware that the new Viceroy, Lord Lytton, was ready to listen in a friendly and considerate manner to all he had to say, with the view of giving such satisfaction to the Ameer as was compatible with the position. Being irritated, however, with the British government, the Ameer followed the example of Dost Mahomed, and opened a correspondence with Russia. Here he was met in quite a different spirit from that in which the British government had treated him ; Russian promises, as in Burnes' time, were considered satisfactory and were believed. Thus in 1876 a deaf ear was turned to the friendly offers made by Lord Lytton, who had replaced Lord Northbrook as viceroy.

Now, there can be no doubt that Shere Ali had for some time contemplated a war with England as the result of his throwing himself into the arms of Russia, and in 
this case he expected great assistance from Russia ; to this end also he by various means had attempted to poison the minds of his subjects against this country, and had pushed on to an extraordinary extent, as already stated, the fortifications, and the manufacture of guns and ammunition, at Cabul.

There are numerous proofs as to the state to which affairs had come. In June, 1875 , Lord Northbrook, writing to Lord Salisbury, says, "The Ameer's language after the return of Noor Mahomed Shah from Simla in 1873 , was certainly far from satisfactory." Again, a sum of $100,000 \mathrm{l}$., placed to the Ameer's credit at Peshawur in 1873 , by the British government, was allowed by him to remain there, and never drawn. Further, he refused to allow British officers to pass through his territory. It was on account of the Ameer having thus made up his mind to throw in his lot with Russia, that the Peshawur Conference of 1876 fell through, because we could not undertake to give him material assistance, and assume the responsibility for the Afghan frontier, unless we had an English agent in Afghanistan to keep us informed as to the state of the country, and of the events taking place outside it ; but this preliminary 
condition the Ameer, with his Russian proclivities, of course declined, and thus the conference came to nothing. The Ameer's next step was receiving the Russian envoy with distinction at Cabul, well knowing that this would give umbrage to us, and thereby demonstrating that his previous refusals to receive our agents arose not from the fear of the risk they would run in Afghanistan, but from other motives. After reviewing these matters, it is difficult to understand that which has been stated by many Liberals, namely, that it was the change of policy which produced the war. Although a great deal was both written and spoken at this time about the war, yet the general opinion in this country was unmistakably in favour of the line of policy adopted by the government; and in India it was considered that the government had adopted the right policy, but that they had gone beyond the bounds of leniency, in giving the Ameer an opportunity for an apology. Both Russia and the Ameer had over and over again declared, the former that Afghanistan was without her sphere of action, the latter that he would not listen to any proposals from Russia.

Yet in the teeth of these promises the 
Russian embassy was sent, and ostentatiously received, and that at a time when there were considerable complications in Europe between this country and Russia, and when no doubt the mission was designed as a counter move against our introduction of Indian troops into Europe. It was therefore to no purpose that the Russian papers asserted, that the mission was a purely friendly mission, not designed to set Afghanistan against England, and too small to cause any fear to the Ameer.

One of the arguments of the Liberal party, at this time, against war with Afghanistan was, that if we made war upon any one, we ought to make war upon Russia, and not upon Afghanistan, for Russia had broken faith with us just as much as Afghanistan. But a clear answer to this argument is, that if it were true that we ought to have gone to war with Russia because she had broken faith with us, then it is a fact that we ought to have been plunged into war with that power many times during the last ten years, and notably so during the administration of the Liberal government at the time of Russia's advance to Khiva. But, the fact of Russia having broken her word, does not absolve the 
Ameer from having broken his ; the more so, as if he had been steadfast, Russia could not have been false. And it was obviously absurd to go to war with Russia in order to get a strong frontier in Afghanistan, our aim being not to reduce Russia's power, but to strengthen our own.

Upon hearing of the reception of the mission from Russia, when our friendly relations with that country were liable to be broken at any moment, and when, had a war with Russia broken out, she would have tried to weaken our position in India, the Viceroy requested the Ameer to receive suitably an envoy from England, who was going to be despatched to him shortly upon important business for the mutual benefit of the two governments. To this request the Ameer returned no answer ; but when Major Cavagnari and a small party advanced beyond our boundary, up the Khyber Pass to Ali Musjid, in order to ask for a safe passage for Sir Neville Chamberlain and the mission, he was distinctly told, that if the mission advanced it would be opposed by force; and further, Faiz Mohammed Khan stated, that Major Cavagnari and his party would have been fired upon, but for the personal friendship which he himself felt for 
Major Cavagnari ; and although warned that his answer would be held to be the answer of the Ameer, he persisted in his direct refusal to allow the mission to pass. It appeared, therefore, that he had received orders from Cabul to that effect. This conduct on the part of the Ameer could not be passed over, and the Viceroy therefore sent a letter to him, giving him time to make an apology before active measures were taken against him, at the same time concentrating troops upon the lines of advance.

When one comes to review the situation, there can be no doubt that Russia was intriguing in Afghanistan in order to obtain her ends in Europe, and intended to harass England by making preparations for a contemplated invasion of India from the north, through Afghanistan, and also by advice and by the distribution of money, desired to raise up the turbulent hill-tribes, and those spirits who, in a large oriental state like India, are always ready to make disturbances in order that they may themselves profit by the overthrow of the existing government. Sir Henry Rawlinson says, "Had the British Conference fallen through in the summer of 1878 , it is almost certain that there would 
have been a Russian military occupation of Afghanistan." How far he is right in the conjecture or not, it is impossible to say, but without doubt Russia would have striven to her utmost to attack us through Afghanistan, though it seems somewhat difficult to understand that she could have done more than raise the country against us, and thereby influence our position in India. The papers taken at Cabul, together with the terms of the treaty between the Ameer and Russia, which have lately been published, clearly show what would have been the result of a war with Russia. The following extracts from the letter from General Stolietoff to Wazir Shah Mahammud Khan, dated 8th October, I 878 , show the advice which was given to the Ameer: "The great Emperor is a true friend of the Ameer's, and of Afghanistan ;" "Whatever our government advises you, you should give ear to it." Then the letter goes on: "Now, my kind friend, I inform you that the enemy of your famous religion (meaning England) wants to make peace with you through the Kaiser (Sultan) of Turkey. Therefore you should look to your brothers who live on the other side of the river (probably meaning the Oxus). If God 
stirs them up, and gives the sword of fight into their hands, then go on in the name of God (Bismilla), otherwise you should be as a serpent; make peace openly, and in secret prepare for war, and when God reveals his order to you, declare yourself. It will be well when the envoy of your enemy wants to enter the country if you send an able emissary, possessing the tongue of a serpent and full of deceit, to the enemy's country, so that he may with sweet words perplex the enemy's mind, and induce him to give up the intention of fighting with you."

As to the treaty; in it, the Russian Government engages to be the perpetual friend of the government of the Ameer. To recognize the heir that the Ameer should appoint. To give assistance to Afghanistan, and to repel any enemy that the Ameer may be unable to drive out.

The Ameer engages, not to wage war with any foreign power without the permission of the Russian Government. To report whatever goes on in his kingdom to the Russian Government.

The Russian Government will fulfil any wishes of the Ameer. Will protect Afghan merchants, and will treat with consideration 
any persons sent by the Ameer to learn arts and trades in Russia.

The publication of these papers has shown the public the position of affairs which led to the late Afghan war; it is to be hoped, that future Viceroys of India will act firmly, as Lord Lytton did, and not be deceived by "sweet words."

It may be noticed here, that Russia has been gradually creeping up towards Afghanistan, while we have remained stationary, relying upon the statement that Afghanistan was outside the sphere of Russian action.

"When the Berlin treaty of January $\mathrm{I}_{3}$ th, I879, was signed, the Russian programme underwent a considerable modification."

In view of the danger involved by Russia's contemplated advance into Afghanistan, it was considered by the government to be wise, and I think it has been abundantly proved that it was wise, to take the steps above-mentioned. Had we sat down quietly under the slight put upon our envoy at the Khyber, our prestige in the crowded bazaars of India would have been gone, and the Sahib would no longer have obtained the respect which he now commands, but instead thereof we should have heard of frequent cases of sedi- 
tious writing in the native newspapers, and sedition breaking out in overt acts in individual cases, for an Oriental cannot understand a policy of leniency, but considers that leniency is a sure sign of weakness or fear.

It was therefore necessary that the imprudent affront offered to this country should be atoned for, and to this end Lord Lytton as already stated, demanded in an ultimatum that a suitable apology should be given, and that a British envoy should be received at Cabul, Shere Ali being allowed till the 2oth of November for his answer. But the Ameer neglected to send a suitable answer to Lord Lytton's letter ; being, doubtless, persuaded to adopt this course, partly by his own conceit and a mistaken estimate of his own power, partly by the advice of his followers, and partly by the promises of assistance, and suggestions of the weakness of England, which were urged upon him by the Russian officers in his capital, at whose head was General Stolietoff.

The time given to the Ameer for his answer to Lord Lytton's letter having elapsed, war was accordingly declared, and on the 2oth of November, 1878, the forces that had been collected on the frontier were put in motion. 
General Biddulph advanced towards Pishin ; General Roberts up the Kuram valley; and Sir Samuel Browne up the Khyber Pass. Numerous offers of assistance from the Indian native states came on all sides.

Sir Samuel Browne was the first to be engaged. He had been encamped for some time previously at Jumrood, which was our frontier fortress towards the Khyber Pass, from the entrance to which it is situated about four miles, being also about ten miles from Peshawur. The old Jumrood Castle was in a somewhat dilapidated condition, but was soon repaired, being composed of but bricks and mud, like most of the buildings in India. A heliograph was established on the walls, by which, communication was kept up with the Khyber Pass and Peshawur, and Jumrood once more became the important place that it has so often been, as the scene of conflicts with the Khyberees, or as the position from which wars against them have frequently been commenced. From Jumrood, Sir Samuel Browne, without any loss of time, made his preparations for an attack on Ali Musjid.

Ali Musjid, or the tomb of Ali, a holy man in whose honour a small temple has been 
erected, is a most formidable position in the Khyber Pass. The fort, which is composed of rubble and mud, stands upon and crowns a rugged, steep, and rocky hill of considerable eminence, which is situated like an island in the centre of the pass. The foot of this hill, on one side, is washed by the river, which is never deep, for even in the very narrowest part of the pass the highest watermark, left by the rains, shows but a depth of six feet. The road up the pass crosses this stream in many places, and at Ali Musjid itself the rocks on either side rise so precipitously that the stream forms the only road up the pass.

These rocky hills, forming the sides of the pass, completely surround the hill upon which the fort of Ali Musjid is placed, and in fact command the fort from several situations ; were it not for their commanding positions, the situation would be one of very great strength, for the hills are exceedingly steep and difficult to climb, and being almost destitute of vegetation in most places, there is but little cover to shelter an attacking enemy. Still, Ali Musjid is, both from the north and the south, a position of considerable strength, and one, which if properly held, would, from 
either side, offer a formidable barrier to an advancing enemy. Sir Samuel Browne knowing therefore, from the nature of the ground, the difficulty of forcing the pass from the front, and being also aware of the dread that the Afghans have of having their line of retreat cut off, ordered Brigadier-Generals Macpherson and Tytler to march with two small columns by a mountain path to the north-east of the pass; this path after making a long circuit through the hills, leads up to the crest of a mountain called Rosas, which commands Ali Musjid on the east. Sir Samuel Browne himself, with the main body, started twelve hours later, to attack the place in front. Unfortunately, owing to the noninterference policy, which has been so long carried on by the Indian Government, we had no good maps, or knowledge of the country twelve miles from our own frontier, and as a result, the march, which had been calculated at twelve hours, took twenty-five, so that the troops under Brigadier-Generals Macpherson and Tytler, instead of taking part in the attack on Ali Musjid in the morning of the 22nd November, found themselves, after marching the whole day, with but little food or water, coming down into the pass on 
the north side of Ali Musjid. Here, after dispersing the Ameer's troops, they were compelled to bivouac in the extreme cold, without food or great coats, the few baggage animals which they had with them being still in the rear, having got delayed in the narrow paths through which they had marched.

Meantime, Sir Samuel Browne, with the remainder of his force, had left Jumrood before daylight, and, having crowned the heights on either side of the road, he had advanced his main body up the pass, following, as well as possible, the road built in 1840 by the celebrated Colonel Mackeson, the engineer who earned so much distinction during the last Afghan war. It was well on in the afternoon before the force arrived in sight of Ali Musjid. The General then advanced a portion of his troops with the mountain guns, to take up a position on his right, while a small party crossed the river to make an attack from the left, the Horse Artillery being placed in the bed of the river, at a bend, where, partially under cover, the guns could fire up into Ali Musjid. The enemy, posted in the fort, and in "sungas," (rough walls built along the mountain sides) kept up a perpetual fire upon our troops from 
their rifles, and also from twenty-five guns of various sizes, which we afterwards captured. Had their fire been well managed much loss must have been sustained, particularly among the Horse Artillery, but their shells were so badly adjusted that they either exploded almost on leaving the guns, or never exploded at all, so that our loss was very trifling. The fire of our guns appeared to make some impression upon the Afghans; and the attack on the left being pushed on, the enemy were driven over two ridges of most difficult ground by the troops under Major Birch. General Sir Samuel Browne, however, finding that the force under Major Birch was not strong enough without considerable reinforcements, to take a third ridge, crowned with a sunga, which was opposed to them, having guns also mounted upon it, and, as darkness was approaching, ordered the attack to cease, and the troops to retire, and bivouac behind the ridge that they had captured, not however, unfortunately, before sixteen of our men had been killed, together with two officers, Major Birch himself, and Lieutenant Fitzgerald.

The next morning it was found that the Afghans, fearing that their retreat had been 
cut off, had evacuated the place, which was, therefore entered without opposition.

After the capture of Ali Musjid the troops advanced by easy stages to Dakka, a place situated on the Cabul river, at the extreme northern end of the pass. Here they remained over a fortnight, until it was decided, towards the end of December, 1878 , to advance to Jellalabad, where, during the war of $\mathrm{I}_{3} 8 \mathrm{8}-42$, as I have already mentioned, General Sale defended himself against the Afghans, until relieved by General Pollock.

During the time which elapsed between Ali Musjid being taken, and the advance to Jellalabad, no serious opposition was offered to the force; occasionally small parties were attacked, single men and camp followers killed, and the pickets attacked at night, or the camp fired upon.

For these attacks, reprisals were taken on our side, being expeditions made into the hills, and the villages of the offenders burnt and destroyed.

These expeditions, although they did not entirely prevent the recurrence of annoyance and outrage on the part of the enemy, were yet of great value in giving us a knowledge of the country, and in forming convenient 
opportunities for accurate surveys to be taken.

A description of one of these expeditions, commanded by General Tytler, an energetic and thoroughly good officer, whose death this year (1880) has been deeply deplored, may not be uninteresting. The expedition started about the middle of December; the parade fell in, in perfect silence, at twelve o'clock at night ; and after marching till about seven a.m., over the roughest of roads (the way lying principally over the dry bed of a river strewn with boulders), just as the day was breaking the force reached a hill, on the further side of which lay, it was supposed, the villages the troops came to attack.

The column, which had been marching in fours, was quickly formed into line, and the men, with great caution, were moved to crown the ridge of the hill in front, strict orders being given that no one should show himself on the sky-line.

The landscape, which had been during the whole march lighted up by a beautiful moon, now gradually changed its tone of colour as the sun rose, and bathed in its first light the distant mountains with blue and gold, casting long shadows over the plains, until, by de- 
grees, the whole country was bright with daylight, except here and there in the valleys, where the mist still hung. Quietly the men waited until the mist in front of them rolled gradually away. At last it is all gone, all is discovered ; but what a discovery! there is not a soul, not a village, nothing but a few empty caves. The force was halted for breakfast, which was heartily enjoyed, the trouble of having carried it all night being little remembered in the enjoyment of eating it in the morning. After resting for some time the force was again on the move, and a short march brought them to a fortified village. Dispositions for attack were quickly made, but it very soon appeared that the place was deserted; upon entering, it was found to be a square-shaped village, fortified with mud and rubble walls, and round towers. After the place had been burnt, and some of the towers blown up, the force returned to camp, where they arrived at about six in the evening, having been on the march eighteen hours. Such expeditions as these, have, during the Afghan war, been very common; sometimes the enemy offered resistance, but in nearly every case they were prepared for the attack, and had escaped 
from the villages, and taken up positions from which they could view the proceedings in safety, and make arrangements for annoying the rear guard when the troops retired.

Sir Samuel Browne's force having reached Jellalabad, remained stationary for some time, until it received orders to occupy Gundamuck, which place we kept in our possession until the conclusion of the treaty with Yakoob Khan.

During this stay at Jellalabad, several expeditions had been made against the enemy, in one of which Brigadier-General Tytler defeated the Shinwaris at Deh Sarrak, and in another Brigadier-General Gough defeated the Khugianis at Futtehabad, in a brilliant action. The stay of the force at Jellalabad was marred by an accident which cost us more than all the actions fought by the Khyber column; a squadron of the Ioth Hussars missed the ford while crossing the Cabul river at night, the current was strong, the horses were swept off their feet, and two officers and fifty men were drowned.

While the Khyber column had been advancing to Jellalabad, General Roberts had taken command of the force assembled at Thull. From that place he advanced, and 
occupied the Kuram fort on the 25 th November, 1878 , and from thence pushed on up the Kuram valley without opposition until he reached Peiwar.

It had been considered by Lord Lytton that in all probability the Ameer would attempt a determined stand against the troops advancing from Kuram; and it had also been considered that it would be most important that the enemy should be defeated here, so that the pass of the Shuturgarden might be gained, and Cabul threatened from thence.

The result fulfilled the anticipations, for on the ist December, 1878 , General Roberts found the enemy, in considerable force, strongly posted on the Peiwar Kotal, and immediately attacked him; but the Afghans fought with so much determination, and the position was so difficult of access, that it was found impossible to dislodge the enemy. The next day, however, the 2nd December, General Roberts determined to make a turning movement, and brought a portion of his force in rear of the enemy, while at the same time he made a front and flank attack. The Afghans were unable to withstand this determined and combined attack now made upon them, and fled with great loss, leaving 
eighteen guns and much ammunition. Our loss was two officers killed, two wounded, and fifty men killed and wounded. The enemy fled over the Shuturgarden Pass, leaving the whole country up to, and including that pass at General Roberts' command; beyond this point, however, the General did not advance, as the Shuturgarden had been fixed as the limit of the operations of his force.

The Afghans in this battle were commanded by Wali Mohamed Khan, half brother to the Ameer Shere Ali ; this man was afterwards a claimant for the throne.

During the movements previous to the defeat of the Afghans at Peiwar Kotal, General Roberts found that some of his troops of Afghan blood, belonging to the 29th Native Infantry, had been communicating with the enemy. These men were therefore tried, one of them was hanged, and the rest sentenced to imprisonment for various terms.

On the 26th of December, 1878, General Roberts issued an address to the chiefs of the Kuram, stating that the British Government had decided that the Kuram would henceforth be placed under British rule, though what form of government would be established, he was unable to state; but this he 
was able to say, that no Afghan Ameer would any longer be permitted to have authority over the country. General Roberts' address was characterized by firmness and consideration; he reminded the Afghan chiefs that they would be expected to repress disorder, that their lives and property would be respected, and everything done to improve the prosperity of the country, but at the same time that any injury to the British Government would be severely punished.

General Roberts then advanced up the Khost valley with a portion of his force, and although the headmen came in, and he was able to obtain supplies, yet he found himself shortly afterwards surrounded by the enemy ; these he defeated in a short engagement, but a detachment left to hold a fortified position, was surrounded as soon as General Roberts retired, and he was therefore compelled to return and relieve the detachment. Finding that the force at his disposition was not sufficient to hold the Khost country, General Roberts abandoned it.

We will now retrace our steps and view the proceedings of the third column, which was acting against Candahar. When the concentration of troops was made all along the fron- 
tier, in consequence of the hostile attitude of the Ameer, General Biddulph was ordered to take command of the force assembled at Quetta.

Quetta, a place which we had obtained by treaty with the Belooch tribes, was at that time our foremost station on the road to Candahar. It will be remembered that during the last Afghan war we considered that the Khan of Khelat had not acted properly towards us, and, under the conception that the frequent attacks made upon our communications had been due to the treachery of the Khan, we despatched a force against him in the latter part of 1839 .

This force, under General Wiltshire, took Khelat after a somewhat severe resistance, in which the Khan himself was killed. We then raised a Khan of our own into power, and since that time the steady good work rendered by our political officers on the frontier, foremost amongst whom, were Major Sandeman and Major Jacob, has resulted in a treaty, which, while preventing much of the internecine strife that had been going on among the Belooch chiefs, since the death of the old Khan at the taking of Khelat, has also resulted in a promise by which the Khan 
and Sirdars engage to keep open the trade routes, and to keep the peace; it has also been arranged that we should maintain some troops at Quetta, as our foremost station, ånd also have an English agent there.

The position thus gained, with but little expenditure of blood or treasure, has proved of great value in the present war, for we were able to transport our troops, free from attack, over a difficult desert country, and concentrate them in a position from which to strike at one of the most important cities of Afghanistan. The march of the troops, for concentration at Quetta, began on the 23 rd of September. In this march considerable difficulty was experienced in crossing the desert, before reaching Quetta, the labour of both men and animals being greatly increased by the heat, which rendered it necessary to march at night, and by the softness of the ground for a considerable distance, which causing the wheels of the guns to sink, occasioned frequent halts, and great exertion on the part of both men and cattle; still, the tribes and the chiefs in the neighbourhood were peaceable, and even friendly, and thus on the 9 th of November, I 878 , the force reached Quetta. 
From Quetta, General Biddulph made recognizances in the direction of Candahar, moving by slow degrees, reconnoitring, and surveying, until the Khojak Pass was reached. Here considerable difficulty arose on account of the roads being mere paths, totally unfit for wheeled vehicles; however, by great exertions the guns were dragged up the steep ascents, and in one place a ramp was constructed, down which they were lowered. Thus by degrees the pass was at last crossed.

While the force under General Biddulph was engaged in passing the Khojak, General Stewart arrived and took command of the whole column. A proper road has now been made over this pass, but the wear and tear for animals and waggons over both this and the Bolan is still very great. The important but small district of Sibi had been already occupied by our troops, in order to secure our communications ; and as the district of Peshin was found to have been evacuated by the enemy, it was likewise occupied. A force was also sent soon afterwards to Kelat-i-Ghilzie, and a garrison placed in the fort.

Almost the first action with this column, took place on the 5 th January, when Colonel 
Kennedy attacked some Afghan cavalry, and drove them before him; in their retreat they were fallen upon by Major Luck and a squadron of $15^{\text {th }}$ Hussars, several were killed, a few taken prisoners, and the rest dispersed. On the 8th January, I879, the force under General Stewart entered Candahar without any further opposition.

Some of the tribes on the line of route attacked the posts left to preserve our communications, but, these were easily dealt with, and shortly brought into good order. Jellalabad, as I have said, had already before this been occupied by the troops under Sir Samuel Browne. Thus Candahar and Jellalabad, two of the principal cities of Afghanistan, were in our possession; in both, the people maintained an attitude of indifference, but the traders and peaceful inhabitants were not displeased at our arrival.

After a short rest at Candahar, General Stewart's force advanced towards the Helmand, ramps being constructed to facilitate the fording of the Argandab, and on the $23 \mathrm{rd}$ of January Atta Karez was reached. During the forward march, the country surrounding the Argandab and Dori rivers, as well as that part called the Doab, was surveyed. 
From Atta Karez the force pushed on to Girishk, an important position on the other side of the Helmand; the fort here was repaired and garrisoned, and an advanced guard pushed on over the plain. The ford of the Helmand at Girishk was found to be between three and four feet deep, with a strong current; hawsers were therefore stretched from bank to bank, and upon these a ferry was constructed which proved very useful. Frequent reconnaissances were made in all directions until the 23 rd of February, when, according to the scheme for withdrawing troops from Afghanistan, the force retired upon Candahar.

In order to effect the retirement, it had been arranged that Colonel Malcolmson should watch the fords from Zamindawar, where an attack had for some time been threatened, forming, when he retired, a rear guard to the column. On the 26th, when at Kushk-i-Nakhud, Malcolmson was suddenly attacked by the enemy ; they were, however, beaten off with the loss of 150 men. Early in March the force left Candahar, and retired via Balozai, to the Bori valley, and the Tal Chotiali valley, that is, by the country northeast, and east of Quetta. 
During this retirement the column commanded by Major Keen was attacked in the Smallan valley, but the enemy was beaten off with considerable loss. This was the only attack made upon the force during its march to the Indus.

The war appeared virtually over, the Ameer had fled to Balkh, in the extreme north of Afghanistan, and it was here that he stated his intention of laying his case at St. Petersburg before the European powers. The Czar, however, declined to intervene in the affairs of Afghanistan, and the Ameer remained at Nazir-i-Sharif until he died, on the 2Ist January, 1879. The Russian mission had left Cabul for Balkh before the Ameer.

Yakoob Khan the Ameer's son, having assumed the reins of government at Cabul, had been induced to come into the British camp after it had been advanced to Gundamuck; there a treaty was signed on the 26th of May, 1879, by him and Sir Louis Cavagnari, making over to England, what is now called the scientific frontier. The articles of the treaty set forth;

That peace shall subsist between the ruler of Afghanistan and the British Government. That the Ameer shall grant full amnesty 
to his subjects, protecting them from all punishment on account of their intercourse with the British forces.

That the Ameer's relations with foreign states shall be conducted in accordance with the advice and wishes of the British Government, and he shall not take up arms against any foreign state without the concurrence of the British Government. On these conditions the British Government will support the Ameer against foreign aggression, with money, arms, and troops, as it may judge best.

If British troops should enter Afghanistan to support the Ameer against foreign aggression, they shall return as soon as they have repelled such foreign aggression.

That a British resident shall reside at Cabul, and that the British Government shall have the right to depute British agents to the Afghan frontier.

That the Ameer guarantees the safety of British agents within his jurisdiction.

That the Ameer will offer no impediment to British subjects peacefully trading within his dominions.

That he will use his best endeavours to ensure the protection of traders, and to facili- 
tate the transit of goods along the wellknown customary roads of Afghanistan.

The improvement and maintenance of these roads, together with the duties to be levied upon "goods carried over them, to be the subject of arrangement between the two governments.

That a line of telegraph be constructed by the British Government, and protected by the Ameer, between the Kuram and Cabul.

That the British Government restores to the Ameer the towns of Candahar and Jellalabad, with all the territory now in possession of the British armies, excepting the districts of Kuram, Peshin, and Sibi, these districts to be treated as assigned districts, and not as permanently severed from the Afghan kingdom, and their revenues, after deducting the charges of civil administration, are to be paid to the Ameer.

The British Government will retain in its own hands the Khyber and Michin passes, and all relations with the independent tribes of the territory directly connected with these passes.

That the British Government agree to pay the Ameer an annual subsidy of six lakhs of rupees, in order to assist him to maintain 
his authority. (A lakh is equal to about Io, $000 l$.)

After signing the treaty the Ameer returned to Cabul, it having been arranged that Sir Louis Cavagnari and a small escort should join him at the capital shortly afterwards.

It will be observed that by this treaty we were to hold the Khyber Pass, which is the recognized route to Cabul, being open at all times of the year.

The Kuram, which is the shortest route to Cabul, being only five marches from that place; this route, which is however closed in the winter, was by the treaty only assigned to us temporarily, but as the inhabitants are opposed to the Afghans both in religion and nationality, they would probably be our good friends.

The third route by the Pishin valley, we were to hold on the same terms as the Kuram, and to retire from Candahar; Quetta, and the Bolan Pass, being left in the hands of the Khan of Kelat.

The inhabitants of the Pishin valley are chiefly agriculturists, who are inclined to our rule, though unfortunately much of the country round is inhabited by wild tribes, who would probably give us some little 
trouble at first. It was suggested that we should assist Persia to take Herat, but this plan, which has not much to be said in its favour, is not now likely to be put into execution.

During this war, which cannot but be taken to have terminated thus far successfully, we had met with but little opposition from the enemy, who evidently did not like meeting us in the open field, or even opposing us from strong and chosen positions. Our chief difficulty had been in transport, yet great credit is, I think, due to the Commissariat, for there were always sufficient supplies of food for the troops, though no doubt great loss and expense was occasioned amongst the transport animals by their being ill-fed, over worked, and badly loaded; yet nowhere were heard those complaints which in the Crimean war, Punch so fitly described in the sentence, "That one man's preserved meat was another man's poison." 1

The treaty having been settled, there appeared to be no further occasion for the troops

${ }^{1}$ Sir Richard Temple has estimated that the loss of camels from the commencement of the war in 1878 to towards the end of $\mathrm{r} 880$, amounted to 40,000 , and this chiefly through want of proper transport organization. 
to remain in Afghanistan; they were therefore withdrawn from all places except those that it was considered advisable to occupy in order to protect our new frontier. This withdrawal of the troops was, unfortunately, not effected without great loss, on account of the unhealthiness of the passes, and particularly of the Khyber, during the hot summer.

On July 24th Major Cavagnari and his escort, consisting of Mr. Jenkins of the Punjab Civil Service, Dr. Kelly, and Lieutenant Hamilton of the Guides, with twenty-six troopers and fifty infantry of the Guides, entered Cabul.

On the journey to Cabul both Sir L. Cavagnari and General Roberts expressed their satisfaction at the arrangements the Ameer had made in their honour, and Cavagnari describes his reception at Cabul, on 24 th July, as, "most brilliant."

From Cabul Cavagnari reported on August the 3 rd, that six Afghan regiments of infantry had arrived from Herat.

Letters from Herat, in May, had described that city as in a state of confusion, the merchants having buried their goods and closed their shops on account of the unsettled state of the government; and now the roads also 
in many parts of the country were unsafe. On August the 6th, Cavagnari received alarming reports as to the insubordination of the regiments from Herat, and on August 24th, Cavagnari reports want of conciliation in the bearing of the Ameer towards his chiefs ; but all went well until September 3 rd, when three regiments broke out in mutiny and attacked the Residency ; after a considerable struggle, in which great loss was inflicted upon the enemy, the Residency was set on fire, and Sir Louis Cavagnari and his escort were killed almost to a man.

It appears, that on the 3 rd of September three regiments assembled without arms for their pay; some dispute arose on account of arrears, which they claimed, but which were not granted to them; this seemed to have aroused a spirit of mutiny, which turned to vent its fury upon the Ameer and the British embassy, lighting up the discontent which had been produced by various and numerous reforms not taking place, as was expected, on the arrival in Cabul of the British envoy.

The mutineers commenced by throwing stones at the Residency, the Afghan Commander-in-Chief Daud Shah Khan, and the Ameer's quarters. The British troops seem 
to have closed the Residency doors and commenced preparations for attack, the mutineers ran for their arms, and forthwith a regular attack was made upon the Residency; Sir Louis Cavagnari was wounded by a bullet, and shortly afterwards killed by the falling of part of the house; the Residency was set on fire; several charges were made by the little garrison, headed by Lieutenant Hamilton, Mr. Jenkyns, and Dr. Kelly. Both natives and Europeans fought most bravely, until at last, all being either killed or wounded, resistance was at an end, not however before great loss had been inflicted on the enemy, who are said to have lost about 400 men. The attack had lasted from eight in the morning till the evening. In their expectations of plunder the Afghans were greatly disappointed, for the Residency being burnt, all in it was destroyed, except some coin, which the Ameer seized a few days after the attack.

There seems to be no doubt that the attack, though not premeditated, had been hinted at before, and that the position of the members of the embassy was not by any means a safe one, the turbulent spirits being ready to attack them at any moment, the 
Ameer not being able to defend them, and himself a doubtful friend. The Residency, situated in the Balla Hissar, was incapable of a protracted defence, and was not properly supplied with water.

That the Ameer promoted the attack seems improbable, but that he might have done more to suppress it is almost certain ; the only efforts he seems to have made in this direction were by sending Daud Shah Khan to reason with the mutineers, and by sending Yahya Khan with a Koran, and also some Syuds and Mullahs. These, however, had no effect upon the mutineers, Daud Shah in fact being beaten, and severely wounded by them.

Sir Louis Cavagnari seems to have disregarded the warnings of danger which were from time to time conveyed to him; his plucky answers being, " Dogs that bark don't bite," and, "If we four were killed, the British Government would lose little, as there are plenty of other officers to take our places."

In Major Cavagnari's small head, and sharp eyes, everlastingly concealed by spectacles, there lay a keen intellect, supported by a sanguine and ardent temperament, which, 
backed by great courage, and a very considerable knowledge of the border tribes, rendered him one, particularly open to enterprises of danger, and ready at all times, without regarding the risks, to go with a small force, to any part of the country. Major Cavagnari received, at various times, much applause for the able way in which he carried out his duty, and Lord Lytton has testified his personal friendship for Sir Louis Cavagnari, and the high appreciation which was on all sides felt for the signal ability with which he conducted the Afghans affairs. Yet, viewed by the wisdom derived from subsequent events, it appears, that it would have been far more prudent to have allowed the Ameer time to settle his newly acquired power, before valuable lives were risked in what has always been a hazardous situation. We had obtained the right, by treaty, of having an envoy at Cabul, and therefore could always have sent our representative whenever we wished; it was hardly, likely, that Major Cavagnari's stay at Cabul would increase the power or popularity of the Ameer, and, although it was by the Ameer's wish, that Major Cavagnari went to Cabul in preference to any other part of Afghan- 
istan, yet there cannot be much doubt that the Ameer would have preferred, that, for the present, the visit should have been postponed, so that, without appearing to be under our tutelage, he might have derived power from our prestige.

As soon as the news of the massacre of Major Sir Louis Cavagnari and his escort, reached India, energetic measures were at once taken to avenge the outrage.

General Roberts, who was in India on account of the army commission, then sitting, immediately left for the Kuram. General Massey was ordered to reoccupy the Shuturgarden Pass, and General Stewart to reoccupy Candahar, while at the same time an additional force of 6500 men was detailed for the Khyber route, under command of Brigadier-General C. Gough, his orders being to keep open the route from Peshawur to Gundamuck, and to provide a movable column to hold Jugdulluck, and communicate with Cabul.

The only thing which prevented an immediate forward movement, was the want of transport, which had unfortunately not been as carefully kept up as it should have been. It was seen that something must be done to 
put the transport on a more efficient footing, and for this purpose a new office was created, and Lieutenant-General Sir Michael Kennedy, R.E., K.C.S.I., was appointed as Comptroller-General of the Commissariat.

On the 29th of September, General Roberts, having recently arrived, and taken command of the Kuram force, met the Ameer, who had ridden in with a few followers to the camp at Kushi.

Notice was immediately sent to the different tribes in Afghanistan, telling them of the advance of the troops, and letters were sent, by the Ameer, ordering the different chiefs to facilitate the movements of the columns.

The opening of this, the second campaign, was somewhat similar to that of the first, except that the objects were different, for, as in the former campaign, the object had been to strengthen our position in India, and to prevent a dangerous combination from taking place outside our territory, and to bring to bear sufficient stress upon a neighbour who no longer concealed his antipathy to ourselves, and had already offered us a gross insult. Now, the object of the present campaign was, to punish a shameful act of

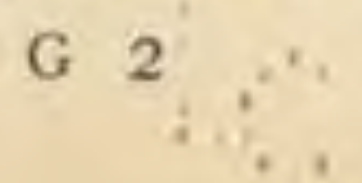


massacre perpetrated upon our countrymen. For this purpose, therefore, it was necessary that the troops should be sent to Cabul, so as to strike at the very scene of the massacre. Whereas, in the former campaign, which was undertaken simply against the ruler, and not against the inhabitants of Afghanistan, the object had been, not to advance further into the country than was absolutely necessary.

To meet this change in the position, while the attack was made on much the same lines as before, the orders were very different; for General Roberts, as being nearest to Cabul, was ordered to advance there as quickly as possible; while, to strengthen our position, General Hughes was detached from Candahar to Kelat-i-Ghilzie; Candahar itself being reoccupied. And General Bright was placed in command of the Khyber column, which was destined to co-operate with General Roberts, and to secure his communications when the line over the Shuturgarden should become impracticable on account of the rigours of the winter. The country now was in a very unsettled state; the Ameer himself in perplexity; the people inflamed with the idea which had been in- 
stilled into them, that they would easily annihilate the British force, after the manner in which they had annihilated Elphinstone's army.

News from Herat arrived, stating the disturbances which had taken place there. Lieutenant Kinloch was murdered on the road near Thull; and the Mangals and Ghilzies attacked General Roberts' force, but were dispersed with loss. The Kuram column advanced as rapidly as possible, and on the 6th of October, the reconnoitring parties sent out from Char Asiab, reported the enemy in force between that place and Cabul.

Here the road and the Logar River run through a deep gorge, flanked on either side by hills, and here the enemy, commanded by Nek Mohamed, one of Shere Ali's brothers, determined to resist the advance of the British troops. The enemy's plans seem to have been, that while the Afghan soldiers and Cabul people held the hills in front of General Roberts, and barred his advance upon the capital, the Ghilzies should act upon the flanks and rear of his force, and also should cut off a large convoy that General Macpherson was bringing up. The 
positions occupied by the Afghans were very formidable, still in order to prevent the enemy from further strengthening these positions, General Roberts ordered an immediate attack. A small force, under Major White, was sent against the enemy, and drove them from the main hill; at the same time General Baker made a turning movement, and was soon hotly engaged. The advance of our troops was made in a rapid and gallant style, that the enemy were unable to withstand, and thus, after a somewhat severe fight, they fled in great confusion, leaving two standards and twenty guns. The Afghans appear to have been surprised at their defeat, and particularly were they surprised at the rapid advance of the British troops ; as they did not seem to have anticipated an advance against Cabul until after the approaching winter, it was doubtless owing to these reasons that the victory was so easily won, for the Afghans had not yet been able to collect in their full strength, and it was probably in view of this, that the Ameer frequently advised delay on the part of General Roberts, being himself, no doubt, in receipt of communications from the enemy. On the $7^{\text {th }}$ of October, General Roberts had 
advanced to within two miles of Cabul; here, learning that the enemy was in position behind the Balla Hissar, arrangements were made both to attack the Afghans, and to cut off their line of retreat; during the night of the 8 th, however, the enemy dispersed, leaving in their position twelve guns, and in the Sherpur cantonment seventy-eight guns.

The cavalry, under General Massey, and General Hugh Gough, were despatched after the retreating enemy, but so completely had they dispersed that only small parties were found together.

On the I 2 th October, General Roberts visited the Balla Hissar, and on the $13^{\text {th }}$, the troops made a public entry into Cabul, without encountering any opposition. The Ameer excused himself from entering the city with the troops, on the plea of indisposition.

A large quantity of ammunition, guns, and treasure, was found at the Balla Hissar, but the only remains of the Residency were a few burnt walls. Search was made for the bodies of Major Cavagnari and his companions, but without success.

Between the $13^{\text {th }}$ and the 2 oth of October, the positions at Ali Khel and Shuturgarden 
were severely attacked, and the Shuturgarden was at one time very hardly pressed; but General Gough came to its assistance, and the enemy were dispersed; also at Ali Khel the enemy came on with great persistence, but were driven back, and a counterattack was made upon them with complete success, by Brigadier-General Gordon. Thus far all had gone well; the Khyber column reached Jellalabad on the 1oth of October, and effected its junction with the Cabul force on November 4th. The only fear General Roberts seems to have had, was as regards supplies; the enemy taken by surprise at the rapidity of our movements, had offered but a small resistance, not having had time to concentrate in full force.

The Ameer appeared unnerved by his troubles, and of his own accord abdicated the throne; General Roberts remaining somewhat doubtful as to whether or no he had instigated the attack on the Residency, and observing, that the Ameer in his present depressed state was quite unfit for the duties of governing the country, consented after a time to accept his abdication; and thereupon General Roberts issued a proclamation calling upon the Afghan authorities, chiefs, and 
sirdars, to continue to exercise their different functions, and stating that he himself would hold supreme control over the affairs of the kingdom, until the British Government should decide upon its course of action; also stating that he had taken over the treasury.

Previous to this, General Roberts had issued a proclamation creating martial law in, and for ten miles round Cabul, and calling for all things taken from the Residency, to be brought in, and offering rewards for the detection of the authors of the massacre; and also for the detection of those who had resisted the British army with the Ameer, since the 3rd September, as by fighting against their Ameer they had proved themselves to be rebels; also forbidding the carrying of arms by all persons, and stating that a fine would be imposed on the city, and that a part would be levelled to the ground, as a punishment for the dastardly attack on the Residency.

A small force was placed in the Balla Hissar, and the rest were encamped outside. Of the men in the Balla Hissar, about twenty were killed, together with Captain Shafto, on October I 7 th, by an explosion of powder with which the place was largely stored. Whether 
the powder had been fired designedly, or by accident, seems very doubtful, but that the explosion was the result of accident seems most probable, as the powder was lying about in all directions.

Two commissions were now ordered to sit ; one for the trial of offenders as set down in the proclamation; and the other, to inquire into the details of the massacre; under these commissions General Saifridin, the Kotwal, and several others were tried and executed. Several small actions took place in various places, in one near Kelat-i-Ghilzie, Sahib Jan, a notorious freebooter, was routed and himself slain; the Shuturgarden was frequently threatened, but attacks were always beaten off, and on the 29 th October that route was closed, the force being withdrawn on account of the approaching winter. Communications were shortly afterwards opened, and kept up by the Latabund route, to Jellalabad and Peshawur.

Later on, that part of General Roberts' proclamation which offered rewards for the detection of those who had fought against the British troops from September 3rd, was rescinded, and free and complete amnesty offered to such persons, provided that they 
should give up their arms, and return to their homes. Nearly 7000 rifles and guns were shortly afterwards brought in, as the result of the various proclamations, and up to November I 5 th, seventy-eight persons were executed in all. Ghuzni and Herat were just now in a very disturbed state; Ayoob Khan at the latter, and Mullah Mushk-i-Alam at the former, were the principal persons who desired to stir up sedition and war against us. The result of the teaching, and religious reputation of the Mullah was such, that the enemy began to collect in large numbers, and so great was the gathering, that it astonished both General Roberts and all the native chiefs in his camp, none of whom seem to have expected so great a rising.

On the first open sign of resistance, General Baker was ordered to march to Maidan, one of the headmen in that district, Bahadur Khan, not having come in when ordered, and a small body of troops which were sent on November 26th to fetch him, having been fired at from his fort, the next day a sufficiently strong force was sent to take the fort, but it was found that the people had fled; the place was therefore destroyed. This was but the commencement of the storm; news 
now kept coming in continually, showing that on every side of General Roberts the country was becoming more and more disturbed, and attacks were now made on our friends, and on small parties of our troops.

As the enemy appeared likely to fight in force, and as it was known that they were coming from different parts of the country in order to bring their united strength against us, it was decided, if possible, to intercept the different parties before they were able to unite. In order therefore to prevent this junction of their forces, General Baker was despatched by the Chardeh route to get in rear of the enemy from Ghuzni, while General Macpherson marched to the Argundeh to meet the enemy, drive them back upon Baker, and prevent their junction with the Kohistanis.

On the Ioth, General Macpherson attacked, not the Ghuzni forces, as he had intended, but those from Kohistan; these he defeated, and proceeded the next day to advance on the Ghuzni road, where General Massey was ordered to join him. General Massey with the cavalry and artillery, pushed on through the valley to join Macpherson, but advancing without sufficient care, found himself in a 
difficult country, much cut up with watercourses, with 10,000 of the enemy in front of him. His cavalry made an ineffectual charge, in which they lost heavily, and Massey was compelled to retreat, leaving four guns; these were, however, shortly afterwards recovered by Colonel Macgregor and General Roberts.

The enemy now attempted to force their way into the camp at Sherpur, but here they were kept in check by two companies of the 92nd Highlanders.

On the 12 th of December, attacks were made in order to dislodge the enemy from the hills; but though successes were gained in one part, they were lost in another, the Afghans being in great strength, fighting very courageously, and being well led. Under these circumstances General Roberts withdrew into his camp at Sherpur, the enemy obtaining possession of Cabul, and of a great deal of treasure and powder which had unfortunately not been taken away or destroyed. The camp at Sherpur was pitched in a fortified position constructed by Shere Ali, and which consisted of a rectangular parallelogram over 2500 yards long, by 1000 yards broad. Thesouthern side of this parallelogram, facing Cabul, was formed of a long range of barracks, 
with a parapet and banquette above them, outside of which was a dry ditch, and a mud wall sixteen feet high, divided and protected by bastions.

The northern side of the parallelogram was formed by the Behmeru hills, a small range rising in an isolated position on the Cabul plain. It had been Shere Ali's intention to carry the fortifications entirely round these hills, but the design had never been completed. In the centre of the Behmeru hills there is a gorge, which formed an exit from the Sherpur encampment, and was protected by block-houses. The ends of the parallelogram were defended in a similar manner to the southern face, but the fortifications were somewhat weaker. General Roberts, having withdrawn into Sherpur, commenced repairing the fortifications, until the morning of the $23 \mathrm{rd}$ of December, when the enemy, at a concerted signal, commenced their attack upon the camp, under the leadership of Mahomed Jan, who stated that he was acting for the young Musa Khan, the heir of the deposed Ameer.

About six in the morning of the 23 rd of December, the enemy's signal-fire was lighted, and shortly afterwards, a feint was made upon 
the south-west angle of the camp; this, however, came to nothing, and the main attack was developed on the north-east angle near the Behmeru village. For a short time this attack was made in great force, and with much determination, the firing being particularly hot, and being replied to with some care on our part, owing to a deficiency of ammunition. However, the enemy failing to make much impression upon the place, his attack began to grow feebler; this apparent feebleness was taken advantage of by General Roberts, who thereupon made a counter attack, and sending out the cavalry in considerable force, was completely successful, cutting up a great number of retreating Afghans. This attack upon Sherpur was the last real stand the enemy made, and General Roberts again became master of Cabul.

The Afghans had, during their occupation of the city, committed great excesses, and plundered the Balla Hissar. The crisis was over, but it had been very severe; it was estimated that at one time 30,000 men were arrayed against us, and such was the determination of the enemy, that General Roberts was obliged to draw in all the small posts on the line of communication, and to call for 
General Gough and a large force to come to his assistance, while the Government of India deemed it necessary to obtain a regiment from the Cape, as well as to delay the return to England of those regiments who would have embarked for this country as soon as their places were filled by the annual reliefs.

While General Roberts was fighting hard for his position at Cabul, the country both about Candahar, and Jellalabad was quiet, the people about Candahar being more disturbed by the rumours of our abandonment of the country, than by the news of the heavy combination against us at Cabul.

Unfortunately these attacks on Roberts' force were not the only way in which the widespread coalition against us showed itself, for on December 23 rd, Jugdulluck Kotal was attacked; on the 24th General Norman was attacked; and on the 29th Gundamuck was attacked, Asmatulla Khan being the leader against us in this last with 2000 Ghilzies of the Lughman valley; but in all these attacks the enemy were beaten off with loss. Meanwhile Yakoob Khan the Ameer, Yahya, Zakaria Khan, and Wazir, were sent to India as prisoners pending the result of the investigations concerning the massacre, as it was con- 
sidered that their being sent out of the country would strengthen our position, because from their power, high rank, and suspected hostility, they were likely to prove dangerous enemies.

In March, 1880, General Roberts having been now a long time fully in possession of Cabul, it was considered wise in order to prevent any further disturbance, to disperse the large number of the disaffected who had collected at Ghuzni. For this purpose General Stewart was ordered to advance from Candahar upon that place. The first brigade left Candahar on the 29th of March, the others shortly afterwards following. On the 6th Kelat-i-Ghilzie was reached, and a detachment of troops, who had held this place during the winter, were picked up ; the force then advanced with but little molestation until the I gth of April, having now covered a distance of about 240 miles. About five a.m. on that day the march began. It was expected that the enemy would shortly make a stand, they having been seen in large numbers the preceding evening. About 7.30 a.m. a large gathering of Afghans was found, posted in a position a few miles in advance of our troops, and dispositions were immediately made, by General Stewart, to attack them. At nine 
o'clock the enemy showed in a thick line occupying a position nearly two miles in length, with a body of horsemen posted on his right, to act against our left flank.

General Stewart says in his despatch (our troops having been formed in line): "The guns had scarcely opened fire, when, in an incredibly short space of time, an enormous mass of men, with standards, formed on the hill top, a considerable number of horsemen riding along the ridge with the intention of sweeping along our line to attack the baggage. From the central mass out rushed successive waves of swordsmen on foot, stretching out right and left, and seeming to develope the position. The horsemen turned the left, now strengthened by a squadron of the igth Bengal Lancers, and pouring down two ravines, which formed a V, struck the Lancers before they could charge, forcing the leading squadron to its right and rear; while the 3 rd Goorkha regiment, the infantry of the left, formed rallying squares."

"The situation during this temporary success of the enemy was rendered critical, as the squadron could not be rallied until it had passed to the right of the line of infantry, then hotly pressed and giving way." 
"The onslaught of fanatic swordsmen was at this time so rapid, and was pushed with such desperation that during the few minutes that followed, it became necessary to place every man of the reserve in the firing line ""the two Sapper companies with half a battalion of the rgth Punjab Native Infantry reinforcing the left, while a half-battalion of the Igth Punjab Native Infantry, with the two companies servingon the Lieutenant-General's escort supported the guns on the left. The enemy, however, continued to push on, and approached within a few yards of the guns, when the whole of their case-shot being expended, both batteries were withdrawn a distance of 200 yards. The gallantry with which the batteries maintained their ground till the last moment, and the orderly manner in which the retirement was effected, reflected the greatest credit on officers and men."

"At this time the infantry of the right was forced back, and a fresh position was taken up, two guns of the G 4th Royal Artillery being detached to the left centre, whither the remainder of the battery was subsequently moved."

"Some well-directed shells from the 40-pounder guns, with No. 6-IIth Royal 
Artillery, checked the forward movement of the enemy's horsemen round our left flank."

"The fighting lasted for one hour, during which the troops under Brigadier-General Barter had come up and reinforced the right centre." At ten o'clock the enemy was completely defeated, and spread over the country, their loss being estimated at between 2000 and 3000 men, our loss being seventeen killed and I 24 wounded. The enemy's force was roughly estimated at 13,000 men, while ours consisted of about 2650 , and twelve guns. The enemy would have been further destroyed had it not been necessary, in the opinion of the General, to reserve the cavalry to protect the baggage.

The next day Ghuzni was entered without opposition. This fight showed the power of the Afghans, for in spite of the steadiness of our troops, and the efficient way in which our guns were served, the enemy, both on the left and on the right of our-position, penetrated our line. On the left, the Afghan horse came suddenly upon the I 9 th Bengal Lancers, forced them back, and galloped through our infantry, who formed rallying squares, while on the right also the Ghazis, some on horseback, and some on foot, got 
within our line, which had consequently to be thrown back.

When the force arrived at Ghuzni, they found the fortifications of the city to be much less formidable than they had been led to expect, many parts of them being commanded by the hills around.

A few days after General Stewart reached Ghuzni, information was brought in, that the Afghans were collected in the neighbourhood in considerable numbers, the defeat of the I 9 th not having quite dispersed them; so on the 23 rd April a force moved out of camp early in the morning, with the intention of surprising the enemy; the surprise was effectual, but the Afghans were found to be posted in a village, against which our small force was unable to act with effect until reinforcements arrived; when, a general advance was made, and the enemy, deserting their villages, fled, many being cut up by the cavalry. Two days later the force, with General Stewart, left Ghuzni for Cabul.

While we were casting about for some one qualified to fill the position of Ameer, Abdurrahman Khan appeared upon the scene. Abdurrahman is, as has been already stated, the son of Afzool, and nephew of the Ameer 
Shere Ali ; he had taken a prominent part in the rebellions formed by his father and uncle against the Ameer; but when, in 1869 , these rebellions were finally put down, Abdurrahman retired across the frontier, and has since been living an exile from Afghanistan, supported, it is believed, by Russian money. This prince now entered the country with a few followers, and, in the belief that, from the capacity he had displayed during Shere Ali's time, he was likely to make a good ruler, negotiations were opened with him on the part of the British Government. Although the position offered to him must have been very tempting, he yet was very slow in accepting that position, and for a considerable time it was doubtful whether it was not his intention to form a party against us; his letters to numerous chiefs breathing a rather warlike spirit against the English, but probably this was nothing but Afghan diplomacy, for he eventually accepted the position of Ameer, and was installed at Cabul, the British Government undertaking to evacuate the place shortly. While these events had been taking place in and about Cabul; Ayoob Khan, the brother of Yakoob Khan, was at Herat. During Shere Ali's rule, Yakoob 
Khan and Ayoob Khan had together governed Herat independently of their father, but when Yakoob was decoyed to Cabul by Shere Ali, and confined there, Ayoob fled from Herat to Persia, where he remained until, on our approach, Shere Ali left Cabul. Ayoob then returned to Herat, obtained admission from Shere Ali's governor, and finally made himself master of the place. He does not seem to have approved of the treaty made by Yakoob Khan with us at Gundamuck, but held himself aloof, trying to consolidate his power, Herat being in a very disorderly state.

When Ayoob heard that his brother had been deposed, he began to collect forces with the supposed object of attacking the Wali of Candahar, who was our friend, and after very considerable delay, he set out from Herat on the 18 th of June. Whether he intended to attack us seems to be doubtful, but his move was calculated to strengthen his position, and he was desirous of collecting the revenue in the country through which he passed.

His forces seem to have increased largely as he went on, so that by the time he reached the Helmand, he had with him a very considerable army, and was well supplied with guns. 
At this time General Primrose was in command of over 4000 men at Candahar, and this force was considered an ample garrison for protecting the town and country at the time.

Shere Ali Khan had been recognized as Wali, and had a native force of Afghans under his orders.

Lord Ripon, who had succeeded Lord Lytton as Viceroy, telegraphed to the Secretary of State as soon as he received the news of Ayoob's advance, that he proposed to instruct General Primrose that the Wali should defend himself beyond the Helmand; but if Ayoob reaches Furrah, a sufficient force is to advance towards Girishk, to prevent Ayoob from passing the Helmand. "This would necessitate moving up reinforcements from Phayre's reserve ;" and he adds, "No troops would be moved until necessity actually arose!" ' When news reached India that Ayoob's advance guard was reported to have arrived at Furrah, the Viceroy telegraphed to the Secretary of State, that he had instructed Primrose and Phayre in accordance with the above.

${ }^{3}$ Telegram from Viceroy 27 th June, 1880 , to Secretary of State. 
From this it would appear that the Viceroy, and in fact the Government in England, did not understand the gravity of the situation; they do not seem to have been aware of the strength of Ayoob's force, and believed that the Wali Shere Ali was strong enough to deal with him beyond the Helmand; this is much to be regretted, but this unfortunately is not all, the Viceroy was evidently aware that it would be necessary to send up reinforcements to Candahar as soon as a force was sent from thence to the Helmand; yet he took no account of the fact that General Phayre's transport was in a state of great disorganization, and that he was totally unable to move at a moment's notice; still, he says " no troops would be moved until necessity actually arose." It is obvious that this was a great mistake, for, when " necessity actually arose" General Phayre would be useless, for he was not in a fit condition to move; and as the affair turned out, he did not arrive at Candahar till after General Roberts reached it in September, two months later. Thus foolish economy became expensive and bad policy.

On the I ith of July General Burrows marching from Candahar with a force of nearly 
3000 men reached the Helmand; here, another unfortunate order restrained him from crossing that river. The Wali, with his troops, was on the further side of the Helmand, and on the approach of Ayoob, he gave notice to General Burrows that there was some disaffection amongst his men, and finally he came over to General Burrows, and requested him to cross the river and disarm the mutinous regiments. This, General Burrows, restrained by the strict order he had received not to cross the river, refused to do, but instead, it was decided that the Wali should move his troops to General Burrows' side of the river, so that if necessary they could be disarmed.

The next day, July I6th, when the Wali attempted to move his force, the Cabul regiments mutinied, seized the guns and baggage, and drove the Wali and his cavalry across the river.

The mutineers having so far succeeded, retired from the camp. After a short delay, a portion of General Burrows' force crossed the river in pursuit of these regiments, and coming up with them, captured the guns, with most of the stores, and inflicted a slight loss upon the mutineers, who quickly dispersed, 
no doubt many of them going to join Ayoob's army. General Burrows now retired from his position on the Helmand, finding that the stores collected for his use by the Wali had been plundered, and that the river, being low at this time of year, was fordable nearly eyerywhere. It was known to the General that the strongest position in rear of the river was at Kushk-i-Nakhud, which lies on the road to Candahar, thirty miles from the Helmand; he therefore considered it advisable to fall back thence, where supplies were abundant, and where the road being narrow, bounded on the one side by the mountains, and on the other by the desert, it would be almost impossible for an enemy to pass unobserved.

Kushk-i-Nakhud is a place, where it has several times been suggested that a permanent fort might with advantage be constructed. Had General Burrows remained in this strong situation and fortified the village, there seems little doubt that he would have been able to keep Ayoob at a distance, until he was in a position to strike a strong blow at him. But General Burrows shifted his camp twice, the second time, with the intention of protecting his sick and stores by an enclosure, 
fearing a night attack from the enemy's cavalry. Thus he remained in great discomfort (for the enclosure was too small for the force) until the 27 th of July, when, hearing that the enemy was in his immediate vicinity, he marched to meet him. General Burrows' force amounted to about 2700 men, and was composed of the following troops :3rd Bombay Cavalry ; 3 rd Sinde Horse; six companies of the 66th Regiment; 1st Bombay Grenadiers; 3oth Bombay Native Infantry (called Jacobs' Rifles); E battery, B Brigade, R.H.A. ; and some native Sappers.

The enemy was variously estimated at between I 8,000 and 25,000 men, with thirty guns; General Burrows' guns consisted of six R.H.A. rifled guns and six smooth-bores, captured a few days previously from the Wali's mutinous troops, and worked by volunteers from the 66th regiment.

General Burrows says in his despatch, dated August, 30th, 1880: "The force marched at $6.30 \mathrm{a} . \mathrm{m}$. on the 27 th July, encumbered by an enormous quantity of ordnance, commissariat stores, and baggage. This was unavoidable, as the hostile state of the country rendered it impossible to leave anything behind in safety, and I could not 
divide my already too weak force." It was the intention of the general to reach Maiwand, a small village about ten miles from his camp, but a short distance from this place the enemy showed in strength, and General Burrows thereupon deployed his force into line on a gravelly plain, placing his cavalry on the left, and his guns in the centre, the 66 th regiment being on the right, with Jacobs' Rifles and the Bombay Grenadiers between them and the guns. The baggage, carried by about 2000 animals, being placed near a village in rear, under charge of a baggage guard of European and native troops.

The battle commenced with artillery fire on both sides, the enemy gradually advancing in line, their infantry being placed in the centre, while their right was covered by a vast mass of horsemen, and their left by large numbers of fanatical Ghazis, considerable forces being also held in reserve, and the guns placed at intervals along the line.

During the artillery combat, and while the infantry were lying down passive spectators in the fight, the baggage guard was twice severely attacked by the Ghazis, but in both their attacks the enemy was driven off with considerable loss. 
About two o'clock, the enemy unobserved, advanced two guns to a position on the right of our line, which they now began to enfilade with an accurate and severe fire, the distance being only about 400 yards.

Our infantry now commenced a heavy fire upon the Afghans, but, notwithstanding the musketry and artillery fire which was brought to bear upon the enfilading guns, they continued to be well served, and to pound shot after shot into our position, so that the fire became exceedingly hot, the cavalry and mounted officers suffering at this time very severely, the ground not affording our troops any protection, while the enemy, advancing by nullahs and hollows, crept up to our line, and about three o'clock a strong body of Ghazis charged the guns, attacking, at the same time, our left and centre; Lieutenant Maclaine, R.A., who had been working his two guns very gallantly all day, was now captured, the remainder of the guns retired, Jacob's Rifles gave way, and, with the Bombay Grenadiers, were driven in upon the rear of the $66 \mathrm{th}$, who were at that time repelling the Ghazis in front of them. The confusion now became terrible, Ghazis, Grenadiers, and Jacobs' Rifles mixed in one 
confused struggling mass, confounded the still, steady 66th. General Burrows rode up, and, with many other officers, attempted to restore some sort of formation among the disordered soldiers, but in vain. The whole mass surged onwards towards the baggage, which had already started on one of the roads to Candahar. Now was the time for reserves, but there were none; now was the time for a charge of cavalry, the cavalry were there, and were ordered to charge, General Burrows himself riding up to them to order the attack, (having no staff officer left), but whether their charge was checked by an order to halt, or, as has been stated, whether they were demoralized by the heavy fire to which they had so long been exposed, or whether they feared to attack this mass of furious swordsmen who had for the first time during the war fairly broken our infantry, does not appear. No doubt, however, remains that the charge was a miserable failure, and comparatively unhurt, except for the casualties of the earlier part of the day, the cavalry drew off, and were joined by the artillery, the smooth-bore guns falling one by one into the hands of the enemy for want of horses. The discipline of the artillery was 
yet as strong as ever, frequently they halted, and checked the enemy with their fire; the native sappers seem also to have retained their order.

For many hours the artillery and cavalry retreated upon Atta Karez, without water, and it was late the next day when they reached Candahar, being met by General Brooke, who had been sent out to bring them in. The retreat of the infantry was a terrible affair, without order and without reason, they pressed on, following the line of baggage animals. The 66 th alone retained their order, and, taking up a position in a walled enclosure, inflicted great loss upon the Afghans, who dared not approach them, but here, they rapidly began to fall before the enemy's fire, till the few that remained received the order to retire. The loss in this retreat of the infantry was terrible; although a rear guard was formed, and several weak attacks that the enemy made were beaten off, yet the men fell in great numbers from exhaustion and thirst, they having taken a road along which the watercourses, at this time of year, are dry, so that few of the whole force obtained any water until seven o'clock the next morning, being then forty miles 
from the battle-field. Though General Burrows has been blamed for the loss of this action, and for this, the only real disaster which we have suffered in Afghanistan, yet all accounts agree, that, under the trying circumstances, he showed indomitable courage and great coolness, having three horses killed under him, and bringing off more than one wounded officer on his horse. Our loss in this affair was about 1000 men killed, very few wounded arriving at Candahar.

General Primrose, in his despatch, gives the greatest credit to the 66th Regiment in this battle; he says that out of 406 men and 19 officers who went into action, Io officers and 275 men were killed, and 2 officers and 32 men wounded. "The officers and men nearly all fell fighting desperately for the honour of their queen and country." And he adds, about "100 officers and men made a most desperate stand in a garden. They were surrounded by the whole Afghan army, and fought until only eleven men were left, inflicting enormous loss upon the enemy. Those eleven charged out of the garden, and died with their faces to the foe, fighting to the death. Such was the nature of their charge, and the grandeur of their bearing, 
that, although the whole of the Ghazis were assembled round them, not one dared approach to cut them down; history does not afford any grander or finer instance of gallantry and devotion to queen and country than that displayed by the 66th Regiment on the 27 th of July, I880." Many instances of individual courage are recorded. Colonel Galbraith, commanding the 66 th, was killed, with his officers and men rallying round him, Captain M'Math falling by his side ; second Lieutenant Barr was shot dead over one of the colours, and Captains Garratt and Cullen were killed while commanding their companies with as much coolness as if on ordinary regimental parade; Lieutenant Honywood was shot down while holding a colour high above his head, shouting, "Men, what shall we do to save this ?" Also Sergeant-Major Cuppage was killed outside the garden while carrying a colour. I do not mention all the other officers who died on this disastrous day, it is sufficient to say that both officers and men all died fighting gloriously, and doing their utmost to resist the tremendous odds against them. Other examples might be recounted, such as that which is mentioned of a Bombay grena- 
dier, who, being badly wounded, requested his comrades to put his cartridges within reach, his body was afterwards identified with only one loaded cartridge remaining.

Thus, although this day was one of terrible disaster, yet it was one that every Englishman might be proud of, as showing that our troops have not degenerated since Cressy or Waterloo, and that whatever the odds are, the British soldier will not hesitate to face them.

No doubt the battle was badly planned, the ground was bad, being cut up with watercourses, so that the cavalry could not act freely to the front, while it was sufficiently level to expose them to a galling fire. No advantage was taken by General Burrows of his greater superiority in manœuvring power ; he fought a short line against a long line, thereby giving the enemy an opportunity of outflanking him on both sides; his information of the strength of the enemy was very bad; and he allowed his men to remain for hours resentless under a heavy fire, which seems to have somewhat demoralized the native troops, particularly the cavalry. If General Burrows desired to fight a defensive battle, he should have chosen his ground, and 
remained in a good position, until Ayoob attacked him. If, on the other hand, he intended to attack the enemy, he should have obtained better information, and as soon as he came up with the Afghans have made a strong attack upon them.

When the news of this disaster reached General Primrose in Candahar, he instantly evacuated the cantonments, and retired into the city, at the same time sending out General Brooke to bring in the remains of Burrows' army, and telegraphing to the Viceroy that Burrows' force had been "annihilated." This precipitation in evacuating the cantonments at Candahar, seems to have caused more excitement, and consequent disaffection in the country, than even the victory, which the native accounts represented as being obtained with such heavy loss on Ayoob's part, that he hesitated to advance. It is supposed, that if a bold front had been shown to him, he might never have ventured another battle before Candahar, where the garrison consisted of about 3000 men. Subsequent visits to the battle-field proved, without doubt that the enemy's loss must have been very severe, long lines of dead horses showing how our artillery fire had told. 
Almost as soon as the troops had hastily evacuated the cantonments, the line between Candahar and India became interrupted, the telegraph was cut, and several of the posts were attacked, and had to be withdrawn.

Amid this general disaffection, it was exceedingly gratifying to the $\mathrm{Viceroy}$ to receive a telegram from the Khan of Kelat, offering transport animals, and stating that he would be happy to do anything in his power for our assistance, his words being, "My head and my all belongs to the British."

After the battle of Maiwand, Ayoob came on slowly to Candahar, and took up a position some three miles from the city, he then commenced throwing up siege-works, occupying the villages round, and throwing shells into the city.

The garrison meanwhile set about repairing the fortifications, and making their position as strong as possible; the disaffected of the population were turned out of the city, extra wells were sunk, as the water supply was not large, though fortunately there was no want of provisions; the citadel was occupied in great force, and the garrison felt confident that they could defend their position against all Ayoob's attacks. 
As General Phayre was not in a fit state to move on Candahar, for want of transport, and as a large and highly-disciplined force was still at Cabul, with Generals Stewart and Roberts, it was decided that the promised evacuation of that part of Afghanistan should be carried out, and while General Stewart retired his force by the Khyber to Peshawur, General Roberts should move on Candahar, and raise the siege of that city.

It was obvious that in this march, General Roberts would have to cut himself adrift from all communications, as even if General Stewart remained at Cabul, he could not keep up communications with Roberts, the distance that general had to march being over 300 miles, neither could General Roberts spare troops for that purpose.

General Roberts started on this hazardous and daring march on the 9th of August, taking with him certain supplies for the European troops, but trusting for the chief part, to what he could collect en route. As the country over which he would have to march was known to be very rough, the general took with him no wheeled carriages, all his baggage being transported by animals, even his guns being carried on elephants. His 
force consisted of over 9000 men of all arms. For nearly three weeks General Roberts and his army disappeared, very few tidings coming of their movements, while great anxiety was felt both at home and in India, at this bold expedition, which, it was held, could only be justified by success. However, the troops marched remarkably well ; the people around were quiet; and supplies came in plentifully, the country traversed being one which had not been before used up by the passage of troops, and the Ameer exerting all his influence to induce the country people to bring in provisions. Large supplies were collected for the arrival of the troops at Khelat-i-Ghilzie, and the garrison of that place was brought on to Candahar.

During the time that General Roberts was performing his march, some fears were felt as to whether the garrison of Candahar would be able to hold out until relieved; the fears proved groundless, for Ayoob's proceedings before the city were very feeble; beyond sending a few shells into the place, he did little or nothing, except occupying the country close up to the walls. General Primrose on his side, made one sortie, with 
the object of dislodging the enemy from a position on that side towards which it was expected General Roberts would arrive, and also with the idea that a successful sortie would strengthen the moral of his troops, and weaken the confidence of the Afghans. For this purpose he attacked the village of Deh-i$\mathrm{K}$ wajeh, which lies close to the city, and in fact, is connected with it by a row of small houses running up to the walls. The suddenness of the attack drove the enemy out of the village, but our troops were unable to clear the place, and the enemy after their first surprise gathered in great strength, and attacking our men, forced them to retreat with considerable loss, we losing nearly 200 men out of a total of about 1000.

Meanwhile the retirement from Cabul had been carried out. On the IIth of August, General Sir Donald Stewart evacuated Sherpur, after a friendly interview with the Ameer, who came to the camp to wish the general farewell; it was very satisfactory that the Ameer should come of his own accord to the camp, as it showed the success which General Sir Donald Stewart had achieved in his dealings with the Afghans, both here and in other parts of the country. The number of people 
who accompanied General Stewart in his retirement was very large, it was estimated that, about 30,000 persons, troops, camp followers, and others, together with near 20,000 animals retired along the Lataband route, for Jellalabad, and Peshawur. This march was safely terminated without resistance on the part of the Afghans.

Since General Burrows' defeat at the battle of Maiwand, General Phayre had been using all his endeavours to get his division in order for the march; in this, he was much assisted by the new railway which had been opened as far as Sibi ; but such was the deficiency of transport, that he was unable to reach Candahar before General Roberts.

On the 3 ist of August, after doing the last two marches very easily, in order that the troops might be fresh, General Roberts reached Candahar. The cavalry were sent out, the same day, under General Hugh Gough, with Colonel Chapman, to reconnoitre the enemy's position. These without loss to themselves drew the enemy's fire from all points, so that his dispositions were pretty well ascertained.

The next day, the ist of September, orders 
were issued for the attack. The enemy occupied a position about three miles north of Candahar, on a range of hills that run in a direction from south-west to north-east, and through which there are two passes, called respectively Baba Wali and Moncha. Here Ayoob had posted the principal part of his force, and many of his guns, of which, in all, he had over thirty. Behind this range of hills, and running in a direction almost parallel with them, flowed the Argandab river.

Between the river, and the south-west end of the range of hills, rises an isolated hill which Ayoob had crowned with guns, and behind this hill, and between the river and the hills, the enemy's main camp was situated. General Roberts' plan was as follows: he made a feigned attack upon the front of the enemy's position along the range of hills, and for this purpose the heavy battery and the Candahar garrison were detailed. At the same time he sent the greater part of his cavalry, with General Hugh Gough, to the extreme right of the enemy's position, near the Argandab river, to cut off the enemy's retreat towards Girishk, while three brigades, under Macpherson, Baker, and Macgregor, respectively, the whole being 
under General Ross, were placed in a position to attack the south-west end of the range of hills, and the whole of the right of the enemy's position. At nine a.m. the battle commenced, the heavy battery opened fire, which was steadily returned by the Afghans on the Baba Wali Pass, while the 92nd Highlanders and the 2nd Goorkhas advanced against the enemy's right, attacking the village of Sahib Dan that lay between them and the hills, and which was held by the enemy in great force. The village was shelled, and the infantry pushed on to the attack, and although the enemy fought here with great determination, yet they could not resist the assault of our troops, and thus Sahib Dan was carried. The attack was now pressed against another village, called Pir Paimal, situated at the end of the range of hills. A third village called Gundigan, further to the west, being at the same time turned, and the enemy forced to abandon it. To the village of Pir Paimal, and up the hill beyond, the infantry forced their way, the Afghans lining every wall, and occupying all available covert, and refusing to give ground to the fire, but only yielding to the repeated rushes of our men. It was here that our loss was the 
greatest, but the attack was very shortly successful. One of the enemy's camps in rear of Pir Paimal, and also the isolated hill, now fell into our hands, and all combined resistance being over, General Gough started his cavalry up the Khadrez valley after the retreating enemy, while Ayoob's main camp was captured, and the Bombay Cavalry Brigade, who had been stationed with General Burrows opposite to the Baba Wali Pass, was sent in pursuit of the enemy up the Argandab valley. By midday, the whole position was in our hands, the enemy rapidly dispersing. The day had been brilliantly gained, and General Roberts complimented his troops upon their work. Poor Maclaine, of the artillery, who had been taken prisoner at Maiwand, was found brutally murdered near the tent he had occupied. The enemy's loss was computed at 1000 men, and thirty-eight guns fell into our hands; our loss was little over 200 men. The only drawback to the entire success of this action was that the enemy got away rather too easily, our infantry being exhausted, and the cavalry from their positions not being able to inflict the crushing blow upon the retreating Afghans that they might otherwise have done. The effect of the victory was 
most satisfactory, supplies came in on all sides, and everywhere the country was quiet. The battle-field at Maiwand was visited, and stones piled over the graves of those who had fallen. Congratulations were received by General Roberts and his troops on their successful relief of Candahar. A large garrison was now left in the place, the remainder of the troops were withdrawn into India.

The Khyber Pass was now evacuated by our forces, the fortifications built by us at Lundi-Kotal and Ali Musjid being placed in the hands of friendly Afrides, who are to receive pay to keep this route open in our interest; this abandonment of our fortifications to these hill-men has been considered a very dangerous step, as the Afrides are notoriously untrustworthy.

The Kuram has been handed over to a friendly tribe, and thus, the only part of Afghanistan at the end of 1880 in our hands was Candahar, and the communications leading to it. Whether, if Candahar is evacuated, Pishin will be retained is at present doubtful ; it is also much questioned whether it would be any advantage to us to hold it after abandoning Candahar.

The question now remains, what is to be 
done with Afghanistan? Various plans have been promulgated for dealing with this question; of these we will examine the principal, which are as follows :-

1st. That we should annex the whole country including Herat.

2nd, That we should settle some chief, or chiefs, in the country, as securely as possible, and ourselves retire behind the scientific frontier, with, or without Candahar.

3 rd. That we should evacuate most of the country, and continue to hold almost the same frontier as hitherto.

The difficulty of the first plan is, that by taking the whole of Afghanistan we are adding a large tract of unremunerative country to our possessions, for it is recognized that the country will not pay the cost of its occupation; further, we shall have to spend a considerable sum annually, for the next few years, in maintaining large military garrisons in the principal places, to keep order among the warlike and restless population. Also our frontier will have eventually, in this case, to be pushed on to the Hindoo Koosh range of mountains, and in the event of a war with Russia, we should be placed in the position of having to defend that frontier; 
we should thereby be further by some 600 miles from our true base, which is India ; and all oursupplies would have to be broughtacross Afghanistan, through passes swarming with what at present is a hostile population, a population that could not be relied upon; as these people are recognized as being amongst the most treacherous in the world, a people who never can resist the prospect of plunder. Also Herat, being over 300 miles from Candahar, would, in the case of war from the north, be a difficult place for us to defend. For not only should we have to transport the whole of our stores and men from India to Candahar, but also, again, the whole distance further on to Herat, all of which country, over 600 miles, would have to be protected by our troops, for in case of war with Russia she would no doubt do everything in her power to stir up the Afghans in our rear, and although we might run a railway the whole distance, yet it would require protection for its entire length. This railway also would be a costly operation, and could not for some time be expected to pay. Again, every mile that we advance reduces the distance that Russia would have to travel from her base, and it has been abundantly 
proved that one of the chief obstacles to be contended against in carrying on war in these parts, is the difficulty of transport. For these reasons it appears, that the annexation of the whole country would be a mistake, involving expense and danger, without sufficient compensation. The argument on the other side is, that if we do not take Herat, Russia will, and Herat has been frequently described as a most important place; it is situated at a point where the Hindoo Koosh can be most easily crossed by an army encumbered with baggage and artillery; also the country around it is very fertile; and it is capable of being made a base from which to attack India, supplies being drawn from the country round, and through the channels of trade, Herat being a commercial centre. Our object, therefore, is to prevent Herat falling into the hands of Russia. As the holding of Herat is the principal object aimed at by those who hold the desirability of annexing the whole country, so what to do with Herat is the chief difficulty with which those persons have to contend, who recommend either of the other two plans. Now as regards Herat, if we leave it as at present, it is obvious that Russia will soon be within 
easy striking distance of the city; and in the event of war between her and England, her first move would be to seize Herat, and concentrate her troops there, and once there, it would be no doubt a very difficult operation for us to drive her out. When at Herat, she might take her time, and advance whenever she found herself strong enough for the purpose, and at the time of year that was most suitable. In this case we must fight her when she wishes. Either in front of Candahar, probably near the Kushk-i-Nakhud (which is the place to which General Burrows retired to wait the advance of Ayoob Khan), or on the Helmand, but that river being frequently fordable in nearly every direction is not such a good line of defence as might be wished, though at times, when in flood, it is a formidable barrier; or, we must fight in rear of Candahar, in which case the enemy will have ample opportunity for collecting his supplies, and making that city his base; and there can be little doubt that the moral effect of a Russian army in Candahar would be very severely felt in India. Also, it may be said, that should we inflict, upon the advancing Russian army, a decisive defeat on the north side of Candahar, the campaign would pro- 
bably be ended, but if on the south side, it would not be so, for we should not only have to take Candahar, but also to fight whatever forces Russia might have pushed up the country in the direction of Cabul.

Looked at, therefore, from these points of view, it appears that it is unnecessary for us to annex the country at present, though we should use our whole influence to have a friendly and strong ruler at Herat, one who, being our friend, and knowing that we should not interfere with his government so long as he proved friendly, would be ready to give us information of the events which were taking place on his frontier, and whom, if necessary, we could support with arms, men, and money, in case of his being attacked by Russia. Ayoob Khan, who is at present ruler in Herat, is about the worst man we could have there, as not only does he govern very badly (Herat being in a very disturbed state), but also he is bitterly opposed to ourselves.

The annexation of the country round Cabul, would be a loss rather than a gain, for it would require a very large garrison, and therefore be a great expense; and it would be a long time before our authority would be properly respected without frequent expe- 
ditions against different tribes. There is also no doubt, that by holding the Khyber Pass and the Shuturgarden we should command all the influence we required with the ruler of Cabul. Thus much for the annexation plan.

The second scheme is, that we should settle some chief or chiefs in Afghanistan as securely as possible, and ourselves retire behind the "scientific frontier," with or without Candahar. The scientific frontier, as it is called, is a line of country, roughly described as, extending from the Khyber to Quetta, including the Khyber and Michni passes, the Kuram, Sibi, and Pishin.

Our object is, as Sir Henry Rawlinson says, " to obtain a strong, friendly, and independent power on the north-west frontier of India, without however accepting any crushing liabilities in return." By the treaty of Gundamuck, which gave us the scientific frontier, we sought to obtain a strong and defensible mountain frontier, and a position from which we could command Afghanistan, where, by a kind and liberal policy, it was thought we should be able to keep on friendly terms with the Ameer, who, assisted by our advice and prestige, would hold his kingdom 
by a firmer grasp than any of the previous rulers of Afghanistan since our connexion with it. This then, seemed the best solution of the difficulty, and the question of our hold on Candahar, we were at the time the treaty was made, willing to waive, although as now the retention of that place, both on military and economical grounds, was strongly advocated, and as strongly condemned. Still, at the time of the Gundamuck treaty the Government abandoned the idea of holding Candahar, on the grounds that it would be displeasing to the Ameer, and also would prevent his having such a strong hold on Herat. This plan of keeping the scientific frontier in our hands seems to offer the most successful settlement of this difficult question. The reasons for giving up Candahar in 1879 do not hold now, as we cannot at the present moment abandon Candahar, for there is no one to take it; the Ameer is unfortunately not sufficiently settled in Cabul, and is unable to collect the revenue of the country he at present holds, while his capital is not by any means secure, and therefore he is not in a fit state to take over the province of Candahar should we evacuate it. Ayoob Khan will also probably make another attempt on the 
place in a few months, and should he obtain Candahar, and defeat the Ameer, we shall then be in the position of having the country ruled by a man whom we know to be most unfriendly to us ; this will hardly be a satisfactory conclusion to arrive at after so much war. We shall therefore be obliged to assist the Ameer in some way, if we wish him to remain a friendly, or a strong ruler in Afghanistan; if we do not assist him we cannot expect any future Afghan ruler to be our friend, for the present Ameer has more claim to our assistance than it is conceivable that any future Ameer can have; yet if we assist him we shall very likely be drawn into another war, and even although we should only assist him with arms and money, we shall apparently still have the old difficulty of requiring agents in Afghanistan, and consequently wanting information; already the information from Cabul is exceedingly meagre and untrustworthy.

The following are some of the opinions expressed as regards Candahar. Sir Richard Temple has said that the situation of Candahar is such that it must under "all circumstances be held." "The cultivation round Candahar is of the very best in all Asia;" 
"the resources are extremely great." General Biddulph also, in a recent lecture delivered at the Royal United Service Institution, seems to be of opinion that our frontier should include Candahar, and be pushed on beyond that city as far as the Helmand, and for the following reasons:- That the first object of an enemy advancing to attack India would be to seize the Helmand country. Here the principal position is at Girishk, but Girishk is easily defensible, and the enemy leaving it and crossing the Helmand higher up, would expose his right flank; he must therefore take this place; the line of the Helmand would consequently form the first barrier which an invader would meet with, while Kush-i-Nakhud Saidah and Atta Karez could form the second line; these lines would leave the defender with Candahar and all the productive country round it in his possession, and would leave the attacking force in a bare country, with the necessity of drawing his supplies from the Herat district. Hence General Biddulph contends that the possession of these points are most necessary.

If we abandon Candahar the next most important position behind it appears to be the Khoja Amran mountains. These mountains, 
which lie on the further side of Pishin from Quetta, and are crossed by the principal roads, form the only real impediment between the Bolan Pass and Candahar.

General Biddulph says on the extreme north-east corner of the Pishin plain "is Balozai, a position of the highest importance." "From here there are fair open vales, descending gradually towards Quetta and Pishin, and close by we find the passes which lead to Zhob, Bori, and Tal. At Gwal, thirteen miles south, on the road to Quetta, lies the exit of the routes to Sibi and to Tal. Quetta fails entirely, to command these passes, while Balozai does so perfectly." The produce of the country is considerable, and the climate is fair.

Besides these opinions of men who have been over the country, and are well qualified to judge, Lord Napier of Magdala and Colonel Humley have given their opinions that Candahar would be of great importance to us from a military point of view ; for although it breaks our line of defence, still it is situated in a fertile position; the inhabitants around are well disposed towards us, and it affords a good position for observing Herat. Lord Lytton also, the late Viceroy, is strongly in 
favour of our keeping this part of the country, and many other persons of great experience, have expressed the same opinions. The advantages of the scientific frontier over our old line, appear to be very considerable, for with our positions chosen in time of peace, and the necessary fortifications and communications by railway made, we should be able at any time to defend in strength, any given point, or points, with but little trouble and expense, and should have the enormous advantage of knowing every bit of the country; while the enemy, marching for several hundred miles from his base, would have to attack us in these narrow and difficult defiles, which are capable of strong defence, and which have so often proved fatal to other expeditions, but which have always hitherto been passed by the invaders of India without difficulty; the rulers of that country, apparently fearful of the continued expense and trouble of holding these mountains, have never taken proper precautions to defend them against an advancing enemy, but have, instead, trusted to the large forces they were able to bring against him in India, a trust that has so frequently been fatal. And it is here to be noticed, that with our present armament and 
civilizing power, we could hold the hill country on our north-west frontier, with advantage to the people, and at a very much less cost than any other previous rulers of India.

The third plan, which is the plan the Liberal Government now in office seem to desire to carry out, is the evacuation of nearly all the country that we have at present gained, and the retirement to almost our old frontier. And this policy appears to be based upon the considerations that the scientific frontier, and Candahar, can at any time be reoccupied by us, and that it will be more economical to spend a large sum in reoccupying the country when that step becomes necessary, than to spend considerable sums each year in holding it. And it is also asserted, that the late war has vindicated our power, and shown that it is the interest of all rulers of Afghanistan to remain our loyal friends. As to the last part of this argument, it may be answered that even if the rulers of Afghanistan recognize the advantages of being on friendly terms with us, those advantages will not be recognized by the different tribes, who, it has been clearly shown, in the present war, have been taught little by the experience of the inany defeats they have suffered; and it is to 
be remembered, that if these men were properly led, disciplined, and armed, they would prove very formidable enemies. Nothing will effectually teach these tribes respect for our power but the fact, that we remain in the country, and put down all abuses by a firm, strong rule; there is a very vast difference between a strong power always wielding irresistible authority in a country, and the same power making occasional though strong expeditions into the districts adjoining its border. Also it appears probable that sooner or later we shall have to reoccupy our late positions, and as soon as we come to occupy them we shall be in much the same situation as we have been during the late war ; we shall certainly not be in a position of such gross ignorance of the country, and all connected with it, as that to which we were doomed by the policy of masterly inactivity ; still we shall have no friends, at a time when they would be particularly valuable; but, on the contrary, our occupation of the country will once more arouse all the passions of the people against us, and the Afghans will not only hate us, but will join the ranks of our enemies, particularly if there is a prospect of an invasion of India. This will greatly increase 
the danger with which we may be threatened. It is clear that if we leave Afghanistan now, the country will be torn by internal dissensions, and the population will remain the same lawless people that they have ever been ; instead of little by little becoming the peaceable inhabitants that our strong rule, and the protection which we should give to life, property, and commercial enterprise, would in time make them ; while the daring spirits, who are not fitted for peaceful occupations, would form for us, under discipline, very efficient soldiers. There is also this great drawback, that this reoccupation of country might have to be commenced at any time, for the danger with which we are threatened from Russia, is not that she would march a large army into India, but that whenever it was desired to create a diversion against England, a small Russian force composed of daring spirits would enter Afghanistan, form a native army as they proceeded towards our frontier, and disturb our position by forming alliances with native princes, whom we should not be able to control; and thus by sending agents in advance in all directions, stir up sedition against us; and this perhaps without official recognition at St. Petersburg, so that, with- 
out any casus belli against Russia, she would be causing us great uneasiness, forcing us to be prepared for instant war, and obliging us to spend great sums to reoccupy Afghanistan, and this simply because, the political barometer in Europe indicated the possibility of a coming storm ; thus the power of England might be partially paralyzed without costing Russia any expense to speak of. On these points, Sir James Stephen and Sir Bartle Frere have written very ably, as well as numerous other well-known public men.

Another of the arguments upon which the Liberal Government rely for this contemplated retirement from Candahar, (for the Kuram and Khyber have already been resigned) is the expense of the occupation, but at present there are no statistics showing what the expense would be, and opinions differ, one party asserting that the occupation would pay itself, and the other that it would be a great drain on the resources of India. There is no doubt that the railway to Candahar, which would have to be built, would cost a considerable sum, without, for some time yielding much return, but it would open up the country, and Candahar would rapidly become a much more important place than it now is; and 
there seems no great difficulty in making the necessary roads, for Captain Holdich, R.E., lately in charge of the surveys in Afghanistan, stated but a short time ago, at a meeting of the Royal Geographical Society, that the difficulties of road-making "were hardly formidable anywhere, and they gradually diminished as we left the Indian frontier behind."

It has also been stated, that Candahar has already, in many respects, improved under our rule, and that the area of cultivation has been nearly doubled.

Again, another of the arguments used in favour of the abandonment of the country, is that the hill routes are difficult to march through, and therefore it would be far wiser for us to leave these difficulties to the enemy to encounter, while avoiding them ourselves; to this it may be answered that we could scarcely sit still in India while the enemy was collecting large forces at Candahar, Cabul, and Jellalabad, and if we did, the enemy's difficulties could not be very great, for one of the routes, that through the Khyber, is very short, the whole of the pass from Jumrood to Dakka being only about twenty-eight miles long, and traversed through its entire length by a good road, with no very steep incline; while the 
other routes would not present great difficulties, provided that the march was unopposed.

In favour of the retention of Candahar Lord Napier of Magdala has lately printed an able minute, while the Duke of Cambridge and many others have recorded their opinions on the same side.

The abandonment of the Kuram and Khyber routes is of less importance than that of Candahar. For the Khyber has been evacuated chiefly because of its unhealthiness in the summer, and on account of its proximity to our frontier it could with ease be reoccupied. While the Kuram has also several disadvantages as follows : many parts of it which would have to be occupied are unhealthy; there is no prospect of a railway to it for some time; the Shuturgarden is closed for three months in the winter, so that an advance at that time is almost impossible, and the distance to Cabul from Pawil Pindi is longer by this route than it is by the Khyber. Still, were we engaged in a war with Russia, some force would have to be maintained on these routes.

However, the result of these matters lies hidden in futurity, and it will be for history to decide upon the value of the opinions put 
forth on this subject; but it is hardly satisfactory for the men who have fought in, and for the people who have paid for the recent war, to have nearly the whole of what has been gained by great labour and expense cast away, so that all that has been done in the recent campaigns may shortly have to be recommenced from the beginning.

And this in order that the policy of masterly inactivity may be again indulged in, a policy which even its authors would not have ventured upon with the Russians already advanced so far, that Merv is almost within their grasp.

THE END. 



\section{INDEX.}

PAGE

Boundaries of Afghanistan . . . . . . 7

Invasion of India by Darius. . . . . . 8

" $\quad$ " $\quad$ Alexander the Great . $\quad . \quad+\quad 8$

The house of Ghore . $\quad$. $\quad$. $\quad$. $\quad$. 9

Jenghis Khan . . . . . . . . 9

Timur . . . . . . . . . 10

Invasion of India by Baber . . . . . . 10

First battle of Paniput . . . . . . . Io

Humayoon . . . . . . . . . 11

Akbar. Second battle of Paniput . . . . II

The Khyberees defeat Akbar's troops . . . . . 12

Abbas II. . . . . . . . . . 13

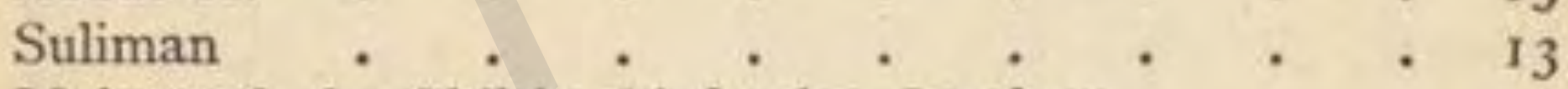

Mahmood, the Ghilzie chief, takes Ispahan . . . 13

Nadir Shah . . . . . . . . . I3

Nadir Shah at Delhi . . . . . . . 14

Ahmed Khan Abdali . $\quad$. $\quad$. $\quad$. $\quad$. $\quad$ I4

Timur defeated . . . . . . . . 15

Fourth invasion of Ahmed Shah Abdali . . . 15

Third battle of Paniput. . . . . . . 15

Timur succeeds his father . . . . . . 17

Zemaun Shah $\cdot$..$\quad \cdot \quad \cdot \quad \cdot \quad \cdot 17$

Scindia and Holkar.$\quad$. $\quad . \quad . \quad . \quad . \quad . \quad 18$

Tippoo Sahib . . . . . . . . 18 
Seringapatam PAGE

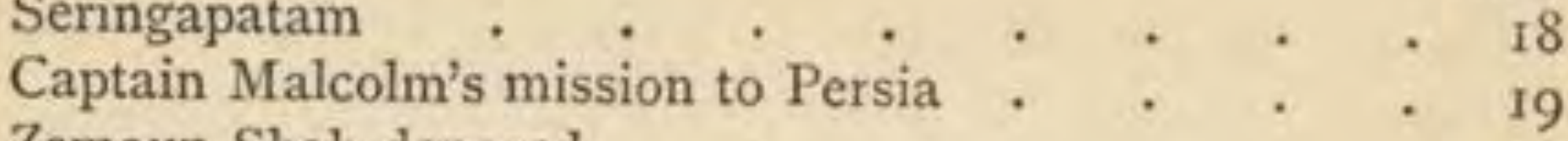

Zemaun Shah deposed $. \quad \cdot \quad . \quad . \quad . \quad$. 19

Shah Mahmoud . . . . . . . . 19

Shah Soojah. . . . . . . . . 19

Second mission to Persia $. \quad . \quad$. . . . . 19

Elphinstone's mission to Shah Soojah . . . . 20

Shah Soojah an exile . . . . . . . 21

Dost Mahomed . . . . . . . . 21

Russia encroaches on Persia . . . . . 22

Our treaty with Persia altered . . . . . . 22

Lord Auckland appointed Governor-General . . 23

Mr. Burnes sent on a mission to Cabul . . . 23

Arrival of Russian agent at Cabul . . . . 23

Runjeet Singh at Peshawur . . . . . . 24

Dost Mahomed turns to Russia . . . . . 25

Lord Auckland adopts vigorous measures . . . $\quad$. 26

Treaty with Runjeet Singh and Shah Soojah . . . 27

Captain Wade . . . . . . . . . . 27

Opinions in England . . . . . . . . 27

Eldred Pottinger . . . . . . . . . 28

Sir Willoughby Cotton . . . . . . . 29

Sir John Keane . . . . . . . . . . 29

The advance against Afghanistan . . . . . 29

Shah Soojah enters Candahar . . . . . . 29

Ghuzni is taken . . . . . . . . 30

Khelat captured . . . . . . . . . $3 \mathbf{I}$

The Russian expedition to Khiva . . . . . 31

Shah Soojah settled at Cabul $\quad . \quad$. $\quad . \quad . \quad .32$

Macnaghten contented with the peaceful appearance

of the country . . . . . . 32

Signs of the coming storm $\quad$. $\quad . \quad+\quad . \quad+32$

General Elphinstone . . . . . . . 33

The expense of the occupation . . . . . 4

Macnaghten reduces the pensions of the Afghan chiefs 34

Sir Alexander Burnes murdered . . . . . 34 
PACE

The insurrection increases . . . . . 35

Proposals to retreat . . . . . . 36

Macnaghten murdered . . . . . . 37

General Nott at Candahar . . . . . 37

Sir Robert Sale at Jellalabad * . . . $\quad$ • 37

General Elphinstone evacuates his cantonments at

Cabul . . . . . . . . . 39

The retreat from Cabul. . . . . . . $4 \mathrm{I}$

The only survivor, Dr. Bryden . . . . . 42

Advance from Peshawur to Ali Musjid . . . . 42

The advance fails . . . . . . . 43

General Pollock at Peshawur . . . . . 43

General Pollock advances and relieves Jellalabad . 44

General Pollock advances to Cabul . . . . 45

General Pollock defeats Akbar Khan . . . . 46

General Pollock reaches Cabu . . . . . 46

General Nott captures Ghuzn . . . . . 46

The "Proclamation of the Gates" . . . . 46

The English prisoners reach General Pollock's camp . 48

The end of the first Afghan War . . . . . 48

Dost Mahomed regains the kingdom of Afghanistan . 49

England declares war with Persia . . . . 49

Dost Mahomed takes Herat and dies . . . . 50

Shere Ali, the new Ameer, writes to Lord Elgin . . 50

The movements of Russia . . . . . . $5 \mathrm{I}$

Russia takes Khiva $\quad . \quad+\quad . \quad$. $\quad . \quad$. $\quad .53$

Alarm of Shere Ali at Russian advances . . . 53

The Umballa conference . . . . . . 54

The result of the conference . . . . . 55

The Simla conference . . . . . . . 55

The result of the Simla conference . . . . 57

The effect on Shere Ali . . . . . . . $5^{8}$

The result of the masterly inactivity policy . . . 59

The Ameer's complaints . . . . . . 60

The Ameer in 1876 . . . . . . . $6 \mathrm{r}$

The Ameer receives a Russian envoy at Cabul . . 63 
PAGE

The opinion in England and India on the policy of the Government .

The object of the Russian mission

The Ameer is requested by Lord Lytton to receive an

English envoy . . . . . . . 65

Major Cavagnari advances up the Khyber Pass . . 65

The Ameer refuses to allow the mission to advance . 66

The Viceroy demands an apology from the Ameer . 66

Russia and Afghanistan . . . . . 66

General Stolietoff's letter to Wazir Shah Mahammud

Khan . . . . . . 67

The Russian treaty with the Ameer . . . . 68

The necessity of the war . . . . . . 69

The Ameer neglects to send a suitable answer to Lord

Lytton's ultimatum . . . . . 70

The war commenced . . . . . . . 70

Sir Samuel Browne's division . . . . . $7 \mathbf{r}$

Ali Musjid . . . . . . . . . $7 \mathbf{r}$

Movements of Brigadier-Generals Macpherson and

Tytler. . . . . . 73

The attack on Ali Musjid . . . . . 74

Ali Musjid evacuated by the Afghans . . . . 76

The advance to Jellalabad . . . . . 76

An expedition into the hills . . . . . 77

Deh Sarrak and Futtehabad . . . . . 79

Accident to the roth Hussars . . . . . 79

General Roberts and the Kuram force . . . 79

The attack on the Peiwar Kotal . . . . . 80

General Roberts' address to the people of the Kuram

Valley . . . . . . . $8 \mathrm{I}$

General Roberts advances up the Khost Valley . . 82

General Biddulph at Quetta . . . . . $8_{3}$

Quetta. . . . . . . . . 83

The Khojak Pass . . . . . . . . . . 85

Sibi, Peshin, Kelat-i-Ghilzie . . . . . . 85

Candahar occupied . . . . . . 86 
The Helmand

Retirement from Candahar . . . . . 87

Action at Kushk-i-Nakhud . . . . . 87

Death of the Ameer . . . . . . . 88

Yakoob Khan becomes Ameer . . . . . 88

Treaty of Gundamuck . . . . . . 88

Major Cavagnari goes to Cabul . $\quad$ - $\quad$. $\quad$ - 93

Massacre of Major Cavagnari and his escort at Cabul . 94

The Ameer's position in relation to the massacre . 96

Disadvantages of Major Cavagnari's stay at Cabul . 97

Opening of the second campaign . . . . 98

The Ameer comes to General Roberts' camp . . 99

The battle of Char Asiab . . . . . . IOI

The troops enter Cabul . . . . . . . J03

Abdication of the Ameer . . . . . . 104

General Roberts' proclamations . . . . . I05

Executions at Cabul . . . . . . . 106

The Afghans rise against General Roberts . . 107

The progress of the rising . . . . . 108

General Roberts retires behind the fortifications of

Sherpur . . . . . . . . I09

The Afghans attack Sherpur . . . . . I10

The Afghans are defeated . . . . . . III

Other attacks in different parts of the country . . I12

General Stewart advances to Ghuzni . . . . I13

General Stewart defeats the Afghans . . . . II4

General Stewart enters Ghuzni . . . . . 116

Second defeat of the Afghans by General Stewart . II7

Abdurrahman Khan . . . . . . . 117

Ayoob Khan . . . . . . . . 118

Ayoob advances against the Wali of Candahar . . II9

Movements to meet Ayoob's advance . . . . 120

General Burrows reaches the Helmand . . . 122

Kushk-i-Nakhud . . . . . . . . 123

General Burrows advances against Ayoob . . . 124

The battle of Maiwand . . . . . . I25 
The retreat from Maiwand . . . . . . 128

General Primrose's despatch . . . . . . 129

General Primrose evacuates the cantorments at Candahar . . . . . . . . ${ }^{1} 32$ Ayoob advances to Candahar . . . . . 133 General Roberts leaves Cabul for Candahar . . 134 General Stewart evacuates Cabul and retires by the

Khyber Pass to India . . . . . . 136 General Roberts arrives at Candahar . . . . 137 General Roberts attacks Ayoob . . . . . 138 The evacuation of the Khyber Pass . . . . I4I The plans for dealing with the Afghan question . . 142 The annexation of Afghanistan . . . . . 142 The retirement behind the scientific frontier . . I47 Opinions on the value of Candahar . . . . 149 Positions behind Candahar . . . . . . 150 The plan of abandoning Candahar . . . . 153 The reoccupation of Afghanistan . . . . . 154 The expense of the occupation . . . . . 156 The improvement of Candahar during our occupation. 157 The abandonment of the Kuram and Khyber routes . ${ }_{158}$

II.

GHLBERT AND KIVINGTON, PRINTERS, ST. JOHN'S SQUARE, LONDON. 


\title{
A CATALOGUE OF
}

\section{NEW \& POPULAR WORKS,}

\author{
AND OF BOOKS
}

FOR CHILDREN,

SUITABLE FOR PRESENTS AND SCHOOL PRIZES.

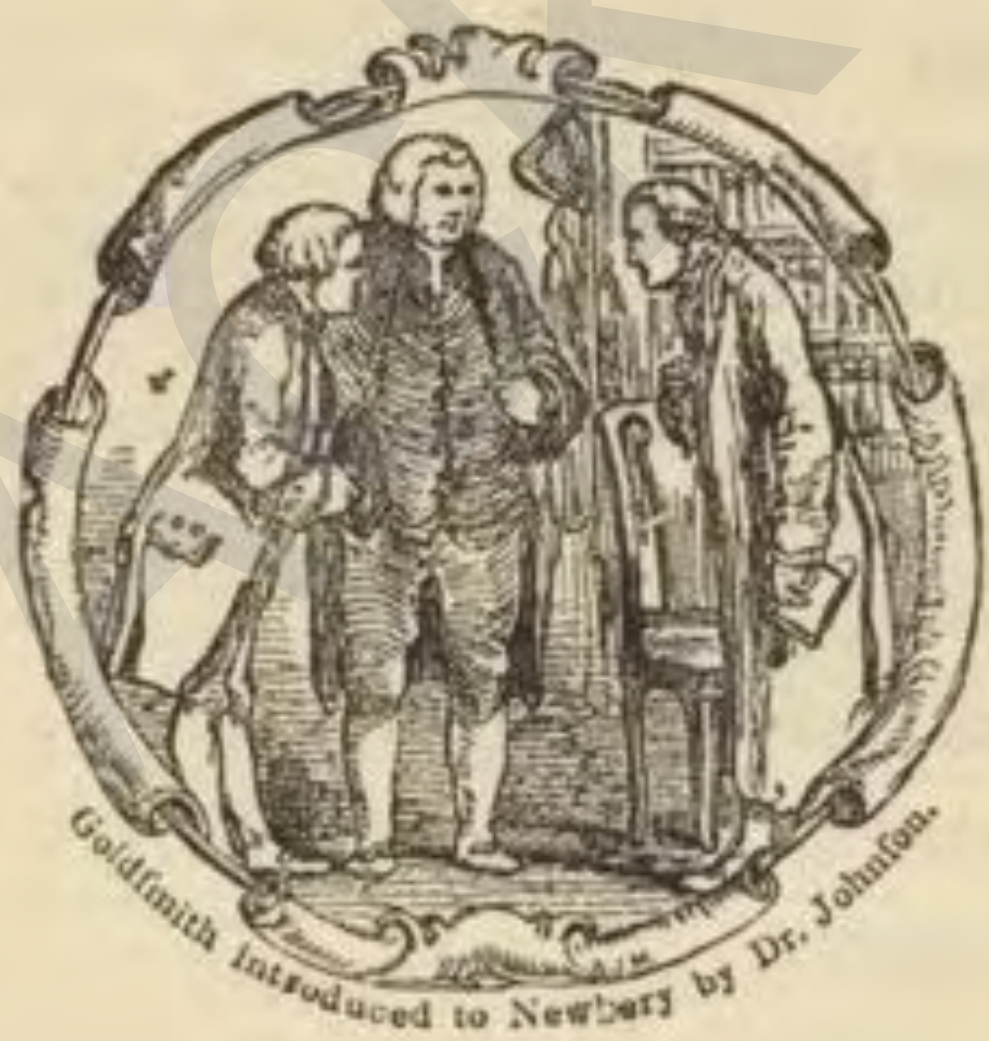

PUBLISHED BY

GRIFFITH AND FARRAN,

(successors TO NKWERRX AND HARrIs),

WEST CORNER OF ST. PAUL'S CHURCHYARD, LONDON. E. P. DUTTON AND CO., NEW YORK. 


\section{CONTENTS.}

New Books and New Editions, $1879-80 \quad \ldots \quad \ldots \quad \ldots \quad 3$

$\begin{array}{llllllllll}\text { Poetry } & \ldots & \ldots & \ldots & \ldots & \ldots & \ldots & \ldots & \ldots & 6\end{array}$

$\begin{array}{lllllllll}\text { New Fiction } & \ldots & \ldots & \ldots & \ldots & \ldots & \ldots & \ldots & 7\end{array}$

$\begin{array}{llllll}\text { Stanesby's Illuminated Gift Books } & \ldots & \ldots & \ldots & \ldots & 8\end{array}$

$\begin{array}{lllllllll}\text { Birthday Books } \ldots & \ldots & \ldots & \ldots & \ldots & \ldots & \ldots & 8\end{array}$

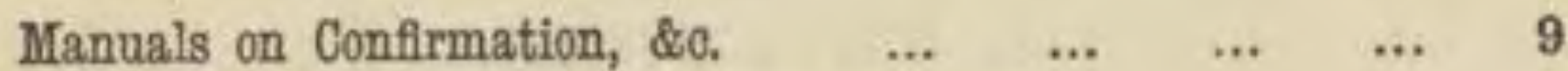

New Books and New Editions for Children ... $\quad \ldots \quad \ldots \quad \ldots \quad 9$

$\begin{array}{lllllll}\text { Ten and Sixpenny Books } & \ldots & \ldots & \ldots & \ldots & \ldots & 10\end{array}$

$\begin{array}{llllllll}\text { Seven and Sixpenny Books } & \ldots & \ldots & \ldots & \ldots & \ldots & 10\end{array}$

$\begin{array}{lllllllll}\text { Six Shilling Books } & \ldots & \ldots & \ldots & \ldots & \ldots & \ldots & 10\end{array}$

$\begin{array}{lllllllll}\text { Five Shilling Books } & \ldots & \ldots & \ldots & \ldots & \ldots & \ldots & 11\end{array}$

$\begin{array}{lllllll}\text { Four and Sixpenny Books } & \ldots & \ldots & \ldots & \ldots & \ldots & 13\end{array}$

$\begin{array}{lllllll}\text { Three and Sixpenny Books } & \ldots & \ldots & \ldots & \ldots & \ldots & 13\end{array}$

$\begin{array}{lllllllll}\text { Three Shilling Books } & \ldots & \ldots & \ldots & \ldots & \ldots & \ldots & 17\end{array}$

$\begin{array}{llllllll}\text { Two and Sixpenny Books } & \ldots & \ldots & \ldots & \ldots & \ldots & 18\end{array}$

$\begin{array}{llllllll}\text { Two Shilling Books } & \ldots & \ldots & \ldots & \ldots & \ldots & \ldots & 21\end{array}$

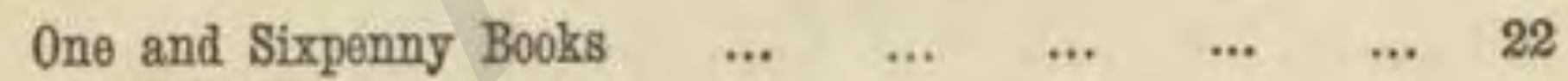

$\begin{array}{llllllll}\text { One Shilling Books } & \ldots & \ldots & \ldots & \ldots & \ldots & \ldots & 23\end{array}$

$\begin{array}{lllllll}\text { The Favourite Library ... } & \ldots & \ldots & \ldots & \ldots & \ldots & 24\end{array}$

$\begin{array}{lllllll}\text { Durable Nursery Books... } & \ldots & \ldots & \ldots & \ldots & \ldots & 25\end{array}$

$\begin{array}{lllllll}\text { Works for Distribution... } & \ldots & \ldots & \ldots & \ldots & \ldots & 26\end{array}$

$\begin{array}{lllllll}\text { Tiny Natural History Series } & \ldots & \ldots & \ldots & \ldots & \ldots & 26\end{array}$

$\begin{array}{lllllllll}\text { Taking Tales } & \ldots & \ldots & \ldots & \ldots & \ldots & \ldots & \ldots & 27\end{array}$

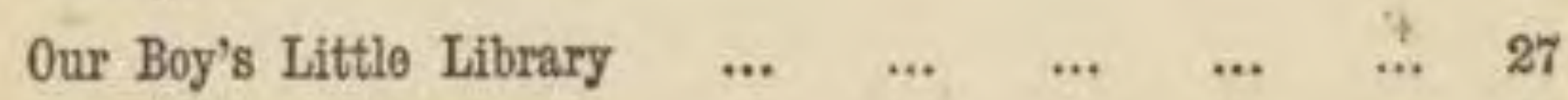

$\begin{array}{lllllll}\text { Our Girl's Little Library } & \ldots & \ldots & \ldots & \ldots & \ldots & 27\end{array}$

$\begin{array}{llllllll}\text { Bducational Works } & \ldots & \ldots & \ldots & \ldots & \ldots & \ldots & 28\end{array}$ 


\section{NEW BOOKS AND NEW EDITIONS.}

THE OTHER SIDE: How it Struck Us. Being sketches of a Winter Visit to the United States and Canada. By O. B. Berre. Demy 8vo., cloth, price 9s,

HEROES OF HISTORY AND LEGEND. Translated by Jous Luscelor Sradwell from tha German "Characterbilder ans Geschiehte und Sage," by $\Lambda$. W. Grune. One vol., Crown 8vo., price 10s. 6d.

A WOODLAND IDYLL. By Miss Phœbe ALLes. It is dedicated to Principal Shairp, and is an attempt to represent allegorically the relative positions of Nature, Art, and Science in our World. Cloth.

[In the press.

THE LETTER H, Past, Present, and Future. Rules for the Silent H, based on Contemporary Usage, and an Appeal in behalf of WH. By ALFred LeAcH. Cloth limp, feap. $8 \mathrm{vo}, 1 \mathrm{~s}$.

TROPICAL READING BOOKS. Intended for use in the West Indies and elsewhere; written at the request of the Right Rev. Bishop Coutrexay, late Bishop of Kingston, Jamaiea. By E. C. PHI..IPs. Profusely Illustrated. In Paper Boards with attractive Wrapper. Book I, price 9d. Book II, price 1s. Book III., price 1s.

DESIGNS FOR CHURCH EMBROIDERY AND CREWEL WORK, from Old Examples, A Set of Eighteen Sheets containing upwards of Sixty Patterns, with deseriptive letterpress, collected and arranged by Miss E. S. HARTBHORNE. In a handsome cloth case, price 55.

A LIFE OF THE PRINCE IMPERIAL OF France. By Ellen Barbee. Demy 8vo, with a Photograph of the Prince, cloth, price 128. 6d.

SIX LIFE STUDIES OF FAMOUSWOMEN. By M. Betham-Edwards, author of "Kitty," "Dr. Jacob," etc. With six Portraits engraved on Steel. Cloth, price 78. 6d. WOTHORPE BY STAMFORD. A Tale of Bygone Days. By C. HoLdich. With five Engravings. Crown 8vo, eloth, price 3s. 6d.

THE BICYCLE ROAD BOOK: compiled for the use of Bicyelists and Pedestrians, being a Complete Guide to the Roads of England, Scotland, and Wales, with a list of the best Hotels and notable places on each journey, population, \&c. By Charles Spexcer, author of "The Modern Gymnast," "The Modern Bicycle," \&c. Cloth, limp, 2s 


\section{THE ART OF WASHING; Clothes, Per-} sonal, and House. By Mrs. A. A. Strasge Burson, author of "On the Leads." Cloth, price 1s. 6d.

AMBULANCE LECTURES : or, what to do in cases of Accidents or Sudden Illness. By Liosel A. WeatrerLy, M.D., Lecturer to the Ambulance Department, Order of St. John of Jerusalem in England. With numerous Illustrations. Dedicated (by permission) to the Ambulance Department of the Order of St. John of Jerusalem in England. Oloth, thoroughly revised, price $1 s$.

\section{DEACONESSES IN THE CHURCH OF} England. A Short Essay on the order as existing in the Primitive Church, and on their present position and work. Revised by the Very Reverend the Dean of Chester. With a Prefatory Note by His Grace the Arohishop of CANTerBury. Post 8vo., Cloth, price 1s. $6 d$.

\section{EIGHT MONTHS IN AN OX WAGGON :} Reminiscences of Boer Life. By Edward F. Sandemax. Demy 8vo, eloth, with a Map, $15 s$.

TRAVEL, WAR, AND SHIPWRECK. By Colonel W. PARKer GmLmoke ("Uigue,") author of "The Great Thirst Land," \&e. Demy 8vo. 9s.

POLITICIANS OF TO-DAY. A Series of Personal Sketches, By T. Wesryss REID, author of "Charlotte Brontë; a Monograph." Cabinet Portraits, \&e. Two Vols., Crown 8vo., eloth, $15 s$.

RECORDS OF YORK CASTLE, FORTress, Court House, and Prison. By A. W. Twyfond (the present Governor) and Major ARTHUR GrIFrrTHs, author of "The Memorials of Millbank." Crown 8vo. With Engravings and Photographs. 7s, 6d.

THE BIRTHDAY BOOK OF QUOTATIONS and Autograph Album. Extracts in English, French, and German, ehiefly from standard authors. With Calendar, Ornamental Borders for Photographs, Album for Translations, and Chosen Mottoes, Extra eloth and gilt, price 10s. 6d.

CREWEL WORK. Fifteen Designs in Bold and Conventional Character, capable of being quickly and easily worked. With complete instructions. By ZErA, anthor of "Ladies Work and How to Sell it," and including Patterns for Counterpanes, Bed Hangings, Curtains, Furniture Covers, Chimney-piece Borders, Piano Backs, Table Cloths, Table Covers, \&c., \&c. Demy. In an Envelope, price 2s. 6d. 
PICTURES OF THE PAST: Memories of Men I Have Met, and Sights I Have seen. By Fravers H. Grusdx, C.E. One vol,, Crown 8vo, , cloth, price $12 s$.

Contains personal recollections of Patrick Branwell Brontë, Leigh Hunt and his family, George Henry Lewes, George Parker Bidder, George Stephenson, and many other celebrities, and gives besides descriptions of very varied experiences in Australia.

\section{STORIES from EARLY ENGLISH LITER-}

ATURE, with some Account of the Origin of Fairy Tales, Legends and Traditionary Lore. Adapted to the use of Young

Students. By Miss S. J. Venables Dopds. Cr. 8vo, price 5s.

THE LIFE MILITANT: Plain Sermons for

Cottage Homes. By ErLeLL. Crown 8vo, price 6s.

HISTORICAL SKETCHES OF THE REFORMATION. By the Rev. Frederrtck Geo. Lee, D.C.L., Viear of All Saints', Lambeth, \&e., \&e., \&e. One volume, Post 8vo., 10s, 6d, eloth.

\section{THE COMMERCIAL PRODUCTS OF THE}

SEA; or, Marine Contributions to Industry and Art. By P. L. Smmonds, author of "The Commercial Products of the Vegetable Kingdom," One vol, with numerous Illustrations, 16 s.

A GLOSSARY OF BIOLOGICAL, ANATOMICAL, AND PHYSIOLOGIOAL TERMS, for Teachers and Students in Schools and Classes connected with the Seience and Art Department, and other Examining bodies. By Thoscas Dusmas, Physiology Lecturer at the Birkbeck Institution and the Working Men's College. Crown 8vo., cloth, 2s. 6d.

THE CRIMEAN CAMPAIGN WITH THE CONNAUGHT RANGERS, 1854-55-56. By Lieut,-Colonel NATHaxiet Stezvens late 88th (Connaught Rangers). One volume, Demy 8vo., with Map, scarlet cloth, 15 s.

"A welcome addition to the military history of England,"United Service Gazette.

MEMORABLE BATTLES IN ENGLISH HISTORY : The Military Lives of the Commanders. By W. H. Davenport Adams. With Frontispiece and Plans of Battles, Two vols, Crown 8vo., eloth, price $16 s$.

OCEAN AND HER RULERS: A Narrative of the Nations which have from the Earliest Ages held Dominion over the Sea, comprising a Brief History of Navigation from the Remotest Periods up to the Present Time. By Alpred ELwEs. With 16 Illustrations by W. W. MAY. Or, 8vo. Price 9s. 


\section{MASTERPIECES OF ANTIQUE ART.}

From the celebrated collections in the Vatican, the Louvre, and the British Museum. By Strphex Thompsox, Author of "Old English Homes," \&c. Twenty-five Examples in Permanent Photography. Super-Royal Quarto. Elegantly bound, price $£ 22$ s.

\section{WORKS BY JOHN TIMBS, F.S.A.}

Notabilia, or Curtous and amusing Facts abodt Many Timings. Explained and Illustrated by Joms Trams, F.S.A. Post $8 \mathrm{vo}, 6 s$. "There is a world of wisdom in this book."-Art Journal.

Ancestral Stories and Traditions of Great Families. Illustrative of English History. With Frontispiece. Post 8v0., price $7 s .6 d$.

"An interesting and well written book."-Literary Churchman.

Strange stories of the Animal World. A Book of Curions Contributions to Natural History. Mlustrations by ZwECKER. Second Edition. Post 8vo, gilt edges, price $6 s$.

"Will be studied with profit and pleasure."-Athenceum.

The Day Dreams of a Sleepless Man: being a series of Papers contributed to the Standard, by FrusK IvEs ScuDAMore, Esq., C.B. Post $8 v e$, price $3 s, 6 d$.

Mission from Cape Coast Castle to Ashantee. Wiтh A Descriptrve ACCount of THAT KingDos. By the late $T$. EDWARD BowDtCH, Esq. With preface by his daughter, Mrs. Hare. With map of the route to Coomassie. 5 .

Joan of Are axd the Times of Churles the Seventi. By Mrs, BRAY, Author of "Life of Stothard," ete. Post 8vo, price 7s. 6d.

The Good St. Louis and His Times. By Mrs. BrAY. With Portrait. Post $8 v o$, price $7 s, 6 d$.

Sagas from the Far East, or KAImoUK AND MONGoLIAN TALES. With Historical Preface and Explanatory Notes by the Author of "Patrañas," etc. Post 8vo, price 9s.

The Vicar of Wakefield; a Talo by OLIver Goldssmth. With eight Illustrations by JoHs ABsolos. Beautifully printed by Whittingham, 3s. 6 d. cloth; $10 \mathrm{~s}$. 6 d. moroceo antique.

\section{POETRY.}

Ambition's Dream. $\triangle$ PozM nN rwo Fytres. New Edition. Feap. $8 \mathrm{vo}$, cloth, $2 s, 6 d$.

Poems. By E. L. Florer. Feap. 8vo, price $2 s .6 d$.

The Seasons; a Poem by the Rev. O. RAymond, LL.B. Fcap, 8vo, with Four Illustrations. Price $2 s, 6 d$, 


\section{NEW FICTION.}

A Life's Atonement. By D. Christie Murray. Three vols., 31 s. $6 \mathrm{~d}$. Worthless Laurels. By Emmx Carrington. Three vols., 31s. 6d. Louis; or, Doomed to the Chorster. A Tale of Religious Life in the time of Louis XIV. Fonnded on Fact. By M, J. Hops. Dedicated by permission to Dean Stanley. Three volumes, 31s, $6 d$.

Tried by Fire. By Fraxcis CARR, Anthor of "Left Alone," \&c. Three vols, 31s. $6 d$.

For a Dream's Sake. By Mrs, Herbert Mantrs, Author of "Bonnie Lesley," \&c. Two vols, erown 8vo, cloth, $21 s$.

The Secret of the Sands; or, The WATER LITY AND HER Crew. A Nautical Novel. By Harar Colnisgwood. Two vols. crown $8 v 0$, eloth, gilt tops, price $12 s$.

\section{STORIES FOR DAUGHTERS AT HOME. \\ Cloth, price 5s,}

Kind Hearts. By Mrs, J. F. B. Frrte, Author of "Sylvis's New Home," \&c. With Frontispiece.

Very Genteel. By the Author of "Mrs, Jerningham's Journal."

Stephen the Schoolmaster. A Srony wrrhout Plor. By Mrs. GeLLIE (M, E. B.)

My Sister's Keeper; ^ Storx for Grrus. In one vol. By Laura M. LANE, Author of "Gentleman Verschoyle," dc. With a Preface by Mrs. Townsend, President of the Girls' Friendly Society.

My Mother's Diamonds. By Marta J. Greer. With a Frontispiece by $A$. Lubovicr.

"Bonnie Lesley." By Mrs. Herbert Martin, Author of "Cast Adrift," \&c. With Frontispiece by Miss C. PAtrasox.

Left Alone; or, the Fortunes of Primlis Martund. By Francis CARR, Author of "Not Lancelot, nor another," \&e.

St. Nicolas Eve and other Tales. By MArY C. Rowsell. Crown 8vo. Price 7s. $6 d$.

Fifty Years in Sandbourne. A Sketch. By Cecrul Lusungron. Feap. 8vo., eloth, 1s. 6d. 


\section{STANESBY'S ILLUMINATED GIFT BOOKS.}

\section{Every page richly printed in Gold and Colours.}

The Bridal Souvenir. New Edition, with a Portrait of the Princess Royal. Elegantly bound in white moroceo, price $21 s$.

"A splendid specimen of decorative art, und well suited for a bridal gift."

The Birth-Day Souvenir. A Book of Thoughts on Life and Immortality. Price 12s.6d. eloth; 18s. moroceo antique.

Light for the Path of Life; from the Holy Scriptures. Small 4 to, price $12 s$. eloth; 15s. calf, gilt edges; $18 s$, morocco antique.

The Wisdom of Solomon; from the Book of Proverbs. Small 4to, price $14 s$. eloth elegant; $18 s$. calf; $21 s$. moroceo antique.

The Floral Gift. Price 14s, eloth elegant; 21 s, morocco extra.

Shakespeare's Household Words. With a Photograph from the Monument at Stratford-on-Avon. New and Cheaper Edition, Price 6s. cloth elegant; 10s. 6d. moroceo antique.

Aphorisms of the Wise and Good. With a Photographic Portrait of Milton. Price 6s. eloth elegant; 10s, 6d. morocco antique.

THREE BIRTHDAY BOOKS.

I. The Book of Remembrance for every Day in the Year. With blank space for recording Birthdays, Weddings, \&c, \&c. Beautifully printed in red and black. Imp. $32 \mathrm{mo}$, prices from 2s. upwards. Or with photographs, from 5s.

$$
\text { * May also be had in various leather Bindings. }
$$

II. The Churchman's Daily Remembrancer. With Poetical Selections for the Christian Year, with Calendar and Table of Lessons of the English Church, for the use of both Clergy and Laity. Cloth elegant, price 2s.; or with photographs, cloth elegant, $4 s$.

* * May also be had in various leather Bindings.

III. The Anniversary Text Book of Scripture Verse and Sacred Song for Every Day in the Year. Cloth, 1s, ; or gilt edges, $1 s .6 d$.

* May also be had in various leather Bindings.

Emblems of Christian Iife. Illustrated by W. HARRY ROGERs, in One Hundred Original Designs, from the Writings of the Fathers, Old Engliab Poets, \&c. Printed by Whittingham, with Borders and Initials in Red. Square $8 v 0$, price $10 \mathrm{~s}, 6 d$. eloth elegant, gilt edges; 21s. Turkey morocco antique.

Bishop Ken's Approach to the Holy Altar. With an Address to Young Communicants. Limp cloth, $8 d$, ; superior eloth, red edges, $1 s$; with Photographs 2s. extra.

** May also he had in various leather Bindings.

$\because *$ Clergymen wishing to introduce this Manual can have specimen copy, with prices for quantities, post free for six stamps, on applieation. 
Confirmation; or Called, and Chosen, and Faithful. By the Author of "The Gospel in the Church's Seasons" series, With a Preface by The Very Reverend the Dean of Cuester. Feap. 8vo, cloth $1 s$.

$A$ cheaper edition for distribution, price $9 d$.

An Illuminated Certificate of Confirmation and First Communion. Price $2 d$.

A New "In Memoriam" Card. Printed in silver or gold. Price 2d. ** A reduction made on taking a quantity of the above cards.

\section{NEW BOOKS FOR CHILDREN.}

Belle's Pink Boots, By Josxse H. Matrmews, Author of the "Bessie Books." With Sixteen Coloured Illustrations by IDA W גשgH. Cloth elegant, $9 s$,

The Union Jack; Vol. I. A Magazine of healthy stirring Tales of Adventure by Land and Sea for boys. Edited, the first portion by the late W. H. G. Krsastos, the second by G. A. Hexty. Copionsly Illustrated. Cloth elegant, price 68 .

Mudge and her Chicks. A Story of Children's Home Doings. By a Brother AND Sister. With Fifteen Illustrations. Cloth elegant, price $3 s .6 d$.

Nimpo's Troubles. By Ourve Thorse Mriner, Anthor of "Little Folks in Feather and Fur." Illustrated by MARx HaLLock and Sol. Extinge, Cloth, 3s, $6 d$.

The Guests of Flowers; a Botanieal Sketeh. By Mrs, Mrerkrkks, With Prefatory Letter by Dr. Treodore Kerser. Cloth small 4to, 2s. $6 d$.

The Cruise of Ulysses and his Men; or, Tales and Adventures from the Odyssey for Boys and Girls. By C. M. BeLL. With Seven Illustrations by P. Priolo. Feap. 8vo, oloth, 2s. $6 d$.

Two Rose Trees. The Adventures of Twin Sisters. By Mrs. Mrexie Dovguas. With Sixteen Illustrations, Cloth elegant, price $2 s .6 d$.

Hilds and her Doll. By E. C. Prrulirs, A uthor of "Bunchy," \&c. With Fourteen Illustrations. Cloth elegant, price 2s. 6d.

The House on the Bridge, and other Tales. By C. E. Bowes, Author of "Among the Brigands," \&c. With Thirteen Illustrations by A, H. Counss. Crown 8vo, price 2s. 6d.

A Daring Voyage across the Atlantic, by two Americans, the Brothers AxDrews, in a Small Boat, "The Nautilus," The Log of the Voyage by Captain Wrinum A. Andrews. With Introduction and Notes by Dr. Macautax, Editor of the "Boy's Own Paper." Illustrations. Crown 8vo, eloth, price 2s. 6d. 
Ten Shillings and Sixpence each, cloth elegant.

Golden Threads from an Ancient Loom; Das Nibelungenlied adapted to the use of Young Readers. By LyDIA HAsDs. Dedicated by permission to THOMAS CARLrLe. With Fourteen Wood Engravings by J. Schvorr, of Carolsfeld. Royal 4to. Child Life in Japan and Japanese Child Stories. By M. Crurris AYrToN. With Seven full-page Mlustrations, drawn and engraved by Japanese artists, and many smaller ones. Quarto, Cloth elegant.

"People who give it away are likely to be tempted to buy a now copy to keep."-Saturday Review.

\section{Nine Shillings, cloth elegant.}

Belle's Pink Boots. By Josxsa H. MAtrhews, Author of the "Bessie Books," With Sixteen Coloured Illustrations by IDA WAUGH. Cloth elegant, $9 s$.

Seven Shillings and Sixpence each, cloth elegant.

The Young Buglers: A Tale of the Peninsular War. By G. A. HeNry, Author of "Out on the Pampas," de. With Eight full-page pictures and numerous plans of Battles.

The Men of the Backwoods; or, Stories and Sketehes of the Indians and the Indian Fighters. By Ascorr R. Hore, author of "Heroes of Young America," \&c. Thirty-three Illustrations.

Six Shillings each, cloth elegant, with Illustrations.

*Kingston's (W. H. G.) Will Weatherhelm : or, THE YARN ON AN OLD SAIDOR ABOUT HIS EARLY LTFE AND ADVENTUREB.

" The Missing Ship, or Notes from the Log of tme "Ouzel GaLLEX."

" The Three Admirals, AND THE Adventures OF THEIR Young FolLowers.

" The Three Lieutenants; or, NAval Liffe IN THE NINEtefanth Century.

" The Three Commanders; or, Actrve Service ArLonT in Modern Trmes.

" The Three Midshipmen. New Edition, with 24 Illustrations by $G$. Thomas, Portch, ete,

" Hurricane Hurry, or THE Adventures of a NAVAL OfHCER DURTNG THE AMERICAN W AR OF INDEPENDFASE.

True Blue; or, The Life and Adventures of a British Seamax of the Old Soroot.

Ice Maiden 1 ND other Stomes. By Haxs Christiux Andersen. 39 Illustrations by ZwECKEn. 4to, Gilt edges.

"Journey to the Centre of the Earth. Authorized Translation. From the French of JULes Vurse. With 53 Mlustrations. 


\section{Six Shillings each-continued.}

Seven Stories about 0ld Folks and Young Ones. By A, R. Hops. (Not illustrated.)

The Bird and Inseots' Post Office. By RoBear Btoomrien. Illustrated with Thirty-five Mlustrations. Crown 4 to. (Or paper boards, chromo sides, 35. 6d.)

The Union Jack; Stirring Tales of Adventure by Land and Sea for Boys. Vol. 1. Fidited, the first portion by W. H. G. KrsasTos, the second by G. A. Hextr.

Little Maids, Rhymes with Illastrations by Mrs. W. Kremp. Quarto, gilt edges.

The Books marked * may be had with bevelled boards, gilt edges, price $7 s, 6 d$.

Five Shillings each, cloth elegant; or Five Shillings and Sixpence, gilt edges. Illustrated by eminent Artists.

Chums: A Story for the Youngsters, of Schoolboy Life and Adventure. By HarLeigh Seversz.

Early start in Life (The), By Esrria Marryat Norris.

Gontleman Cadet (The): His Career axd Advestures at THE Royal A cadeary, Woolwich, By Lieut-Colonel Drayson.

Gerald and Harry, or THe Bors Is the North. By EMrru Marryat Norrts.

Hair-Breadth Escapes, or THE Apventures of TrmeE Boys iN Soutu Africa. By the Rev. H. C. ADsiss.

Heroes of the Crusades. By Barbara Hutros.

Home Life in the Highlands. By Lanas Graeme.

Household Stories from the land of Hofer, or Popular Mrths

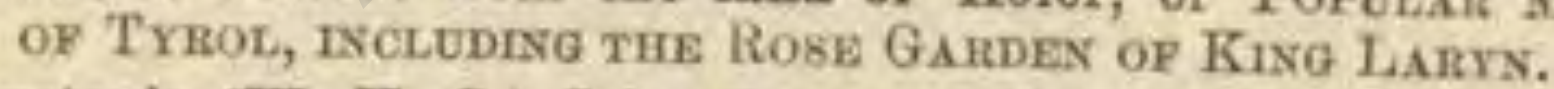

Kingston's (W. H. G.) John Deane of Nottingham, His AvvenTURES AND EXPLOITS.

" Rival Crusoes (The). (Or bevelled boards, gilt edges, 6s.)

Out on the Pampas, or THE Young Serruers. By G. A. Hexrr.

Patrañas, or SPaxish STomes, Legendary axd TradmonaL. By the Author of "Household Stories."

Swift and Sure, or Tre Cameer or Two Brotmers, By A. Elwes. Tales of the Saracens. By Barbara HutTon.

Tales of the White Cockade. By Barbara Hutron.

Workman and Soldier. A TALE OF PARtS LIFE DURTse THE Stege axd the Rule of the Commune. By James F. Conb, (or bevelled boards, gilt edges, 6s.)

Young Frane Tireurs (The), AND THEm ADVRNTUREs DURNo THE Braxco-Prussun War, By G. A. Heatr, Special Correspondent of the Standard. 
Five Shillings each, cloth, Illustrated, gilt edges.

Elwes' (A.) Luke Ashleigh, or School Life in Holluxd.

" Paul Blake, or A Boy's Peruts nN Corsica AND Monte Cristo.

Neptune's Heroes, or, The SeA Krsgs of Exgland, FRo3r HAWKIns to Franklin. By W. H. Davenport Adass.

Talks about Plants, or EARLy Lessons in Botaxy. By Mrs. LANKester. With Six Coloured Plates and numerous Wood Engravings.

\section{A UNIFORM SERIES OF FIVE SHILING VOLS.} Square Crovon 8vo, gilt edges.

The Day of Wonders. A Mediex of Sense axd Nonsense. By M. Sullivan. 30 Illustrations by W. G. Browse.

Harty the Wanderer; or, Conduot is FAte. A Tale by FARLEIGH Owes. 28 Illustrations by JoHs Proctor.

A Wayside Posy. Gathered for Girls. By F. Lablacie. 15 Illustrations by $\mathrm{A}$. H. Cor.hIs

Price Five Shillings each, cloth elegant, Illustrated.

Extraordinary Nursery Rhymes; New, yet Old. Translated from the Original Jingle into Comic Verse by One who was once a Child. 60 Illustrations. Small 4 to.

Favourite Picture Book (The) and Nursery Companion. Compiled anew by UNeLe ChurLIE. With 450 Mlustrations by Absolon, Anelay, BenNett, Browne (Phiz), Sir Johy Gitbert, T. Lasdseer, Lekch, Prout, Harrison Wem, and others. Medium 4to, cloth elegant (or coloured Ilustrations, 10s, 6d.)

** This may also be had in Two Vols., eloth, price 3s., or coloured Illustrations, $5 s$.; also in Four parts, in paper boards, fancy wrapper, price 1s. each, or eoloured Illustrations, $2 s$. each.

Little Gipsy (The), By Eure Sauvage. Translated by AnNa BLACKwELL. Profusely Illustrated by ERNest FröLich. Small 4 to, (or, extra cloth, gilt edges, 6s.)

Norstone; or, Rifts IN the Clouds. By M. E. Hatterslex. Merry Songs for Little Voices. Words by Mrs. Broderrr. Musio by Thomas Murby. With 40 Illustrations, Feap 4to.

Stories from the old and New Testaments. By the Rev. B, H. DrAPER. With 48 Engravings.

Trimmer's History of the Robins. Written for the Instruetion of Children on their treatment of Animals, With 24 Illustrations by Harrison Wrir. Small 4to, gilt edges, 
Four Shillings and Sixpence each, cloth elegant, with Illustrations ; or with gilt edges, $5 s$.

Alda Graham; and her brother Philip. By E. Marryat Norris. "Buttons," The Truals and Travels of a Young Gentreman. By Ascotr R. HoPE.

Casimir, the Little Exile. By Caroline Penchex.

Cornertown Chronieles. New Legends of OLD LORE written FOR THE Young. By Kathlees KNox.

Favourite Fables in Prose and Verse. With 24 beatiful Illustrations from Drawings by Harruson WeIR. Small 4 to.

Fiery Cross (The), or the vow of Mostrose. By Barbara Hettos.

Mandarin's Daughter (The): A StoRY of THE GreAt TAEPING Rebelliox. By Sastuel Mossman.

Modern British Plutareh (The), or Lrves of MEn Distrvevisued IN THE RECEN1 HISTORY OF OUR COUNTRY FOR THEIR TALENTS, Virtues, AND ACHEVEMENTs. By W. C. TAYLOR, LL.D.

Oak Staircase (The), or THE StORIEs of LoRd AND LAADY DesMroND; a Narrative of the Times of Jumes II. By M. and C. Lee.

Royal Umbrella (The), By Major A. F. P. Harcourt, Author of "The Shakespeare Argosy," \&c., \&c. With 4 full-page Illustrations by LINLEY SAMBOURNE.

Silver Linings: or, Light axd Shade. By Mrs, Regisald M. Bruy.

Tales and Legends of Saxony and Lusatia. By W. Westate. Theodora : a Tale for Girls. By Emun Marryatt Norris.

Zipporah, the Jewish Maiden. By M. E. BewsHer.

Three Shillings and Sixpence plain; or coloured plates and gilt edges, Four Shillings and Sixpence, Super Royal $16 \mathrm{mo}$, cloth elegant, with Illustrations.

Aunt Jenny's American Pets. By Catherine C. Hopler,

Broderip (Mrs.) Crosspatch, the Cricket, and the Counterpane.

" Tales of the Toys. TOLD BY THEMserves.

". Tiny Tadpole, and ormer Tales.

Cousin Trix, aNd her Welcome Tales. By Georgina Cratk.

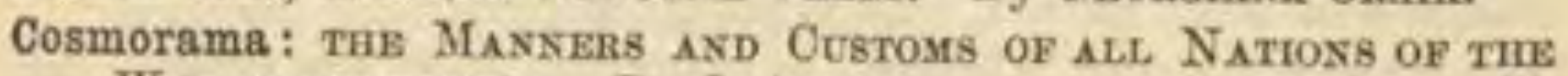

WORLD DEscribed. By J. AsPIs.

Distant Homes, or The Gramas Famim ix New Zealand. By

Mrs. T. E. A rmMER.

Early Days of English Princes. By Mrs. Russell Gray. 
Three Shillings and Sixpence each-continued.

Echoes of an 01d Bell. By the Hon. Avgusta BethetL.

Facts to Correct Fancies, or Short NARratives of Remarkable WoMEN.

Fairy Land, or Rechention for time Rising Generation, in Prose and Verse. By Tromas AND JAxE Hood. Mlustrated by T. HooD, Jun.

Feathers and Fairies, or Storres moom the Rearms ox Fanox. By the Hon. Augusta Bethiri.

Garden (The), or Frederick's Mosthly Isstruction for the Masagement and Formatiox of a Flower Garden. With Illustrations by SowErBy. 6s. coloured.

Haceo the Dwarf, or THe Tower on the Moustais, and other Tales. By Lapy Lusmingtos.

Happy Home (The), or The Chmpres At the Red Hotse. By Lady Lushisgton.

Helen in Switzerland. By the Hon. Avgusta Bethel..

Lightsome and the Little Golden Lady. Written and Illustrated by C. H. Bexnerr. Twenty-four Engravings.

Nursery Times, or StoniEs ABout the Lirrue Oses. By an Old NURSE.

Peep at the Pixies, (A), or Legends of the West. By Mrs. Brax. Seven Birthdays (The), or The Cumbren of Fontune. By Kathleks KNox.

Starlight Stories, told to Brtant Eres axd Listentig Ears. By FANNY LABLACHE.

Stories of Edward AND mis Litrte Friexps.

Tales of Magic and Meaning. Written and Illustrated by ALFred ORoweUIL.

Three Shillings and Sixpence plain, cloth elegant, with Illustrations by eminent Artists, or with gilt edges, price $4 s$.

Cast Adrift, the Story of a Waif. By Mrs. Herbert Martrs.

Castles and their Heroes. By Barbara Huttos.

Clement's Trial and Victory, or Sowisg AND Reaprsg. By M. E. B. (Mrs. Gewire). Third Thousand.

College Days at Oxford. By the Rev. C. H. Adass.

Faggots for the Fireside, or TALES of FAOT AND FAxcx. By Peter Parley. 


\section{Three Shillings and Sixpence each-continted.}

Great and Small; Scrses IN THE Life of CHrLdrex. Translated from the French by Miss Harrierr PooLe. 61 Illustrations.

Grey Towers; or Auns Herry's Wru. By M. M. Polzard.

Isabel's Difficulties, or Lianr ox the Darly Path. By M. R. CARey. Joachim's Spectacles: A Legend of Flonenthal. By M. \& C. Lee. Kingston's (W. H. G.) Fred Markham in Russia, or, Twe Bor Traverlers in the Laxd of the Czar.

" Manco the Peruvian Chief.

" Mark Seaworth; a Tale of the Indian Ocean.

" Peter the Whaler; His EArLy Life AND Adverrures IN THE ARCTIO RegloNs.

" Salt Water, or NeIL D'Arey's Sea Live ANd Adventures. Lee (Mrs.) Anecdotes of the Habits and Instincts of Animals.

" Anecdotes of the Habits and Instincts of Birds, Reptiles, and Fishes.

" Adventures in Australia, or The Wanderings of Captars Spexcer IN THE Besh AND THE WmDs,

"The African Wanderers, or Carlos Axd Axtosio.

Little May's Friends, or Country Pets AxD PAstrimes. By AxNis WhrTes.

Millicent and Her Cousins. By the Hon. Avgosta BerHel..

Mudge and Her Chicks: A Story of Children's Home Doings, By a Brother and Sister.

New Girl (The), or Tue Rrvals; a Tale of School Life. By M. E. B. (Mrs. Gell.Iz).

Nimpo's Troubles. By Ortve Thonese Mrnher, Author of "Littlo Folks in Feather and Fur."

North Pole (The); Axp How Chan.re Wuson Discovered IT, By the Author of "Realms of the Ice King," de.

Our 0ld Uncle's Home; AND wHat THE Bors DID THERE, By Mother CAmer.

Queen Dora: The LrFe axp Lessons of a Lrrmes Gmi. By KATHLEEN Kxox.

Rosamond Fane, or the Prisoners of Sr. JAMrs, By M. and C. LEE.

Talent in Tatters, or some Vicissrrudes IN THE LrFE of AN English Boy. By Hope Wraythe.

The Triumphs of Steam, or Storres fRom the Lrves of WATt, A RKWRight, AND Stephenson.

The Whispers of a Shell, or Storms of rwis Sea. By Fraxces Freeling Broderte. 
Three Shillings and Sixpence each, cloth elegant, Illustrated.

Among the Zulus. By Lreur.-CoL. Drarsos. Cloth, gilt edges.

Attractive Picture Book (The). A New Gift Book from the Old Corner, containing numerous Illustrations by eminent Artists.

Bound in Elegant Paper Boards, Royal 4to, price 3s. 6d. each. plain; $7 s .6 d$. coloured; $10 s .6 d$. mounted on cloth and colonred.

Berries and Blossoms: a Verse Book for Young People. By T. WEsTwOOD,

Bible Illustrations, or A Description of Maxwers AND Customs peculiar to the East. By the Rev. B, H. Draper. Revised by Dr. KrrTo.

British History Briefly Told (The), AND A DEscription of THI Ancient Customs, Sports, AND PAstimes of the English.

Four Seasons (The); A Short Aecount of the Structure of Plants, being Four Lectures written for the Working Men's Institute, Paris. With Illustrations. Imperial $16 \mathrm{mo}$.

Family Bible Newly Opened (The); wrrH Uxche Goodwrs's Account of Ir. By JefFreys Taylor. Feap. 8vo.

Glimpses of Nature, AND OBJECTS OF INTEREsT DESCRIBED DURTNa A Visit to the IsLe of Wighr. By Mrs, Loedon. Fortyone Illustrations.

History of the Robins (The). By Mrs. Trumsrer. In Words of One Syllable. Edited by the Rev. Charles Swete, M.A.

Historical Acting Charades, or Amusements for Wexten Evexrses. By the Author of "Cat and Dog," ete. Feap. 8vo.

Infant Amusements, or How to MAKE A NuRsery HAPPY. With Practieal Hints on the Moral and Physical Training of Children, By W. H. G. Knngston.

Little Margaret's Ride to the Isle of Wight; or, The Woxpenrut. Rocking Horse. By Mrs. Frederick Brown. With Eight Illustrations in ehromo-lithography, by HeLEx $\mathbf{S}$. TATHaM. Crown 4 to.

Man's Boot (The), AND other Stories in words of ONe Syltable. Illustrations by HARRISON WNIR. 4to, gilt edges.

The Mine, or Subterranesx Wosders. An Account of the Operations of the Miner and the Products of his Labours.

Modern Sphinx (The). A Collection of Exigmas, Churades, REBuses, Dodble axd Triple Acrostics, Anagrasis, Logogripgs, Metagrams, Vetral Puzznes, Conundrums, ete. Feap. 8vo.

The Bird and Insects' Post 0ffice. By RoBert Bloomrmed, Anthor of "Rural Tales, ete. Illustrated with Thirty-five Wood Engravings. Crown 4to, paper boards, with Chromo side, (or cloth elegant, 6s.) 
Three Shillings and Sixpence each-continued.

Sunbeam: a Fairy Tale, By Mrs, Pietzker.

Sylvia's New Home, a Story for the Young. By Mrs. J. F. B. FirTH.

Taking Tales. Edited by W. H. G. Krngsrox. In Plain Language and Large Type. New Edition. Two vols.

May also be had in 4 vols, $1 s$. $6 d$. each; and 12 parts, $6 d$. and $4 d$. each.

Three Shillings and Sixpence plain; Five Shillings coloured.

Bear King (The): a Narrative confided to the Marines by JArEs Greeswood. With Ilustrations by Errest Griser. Small 4to,

Familiar Natural History. By Mrs, R. LeE. With 42 Ilustrations by Harrison WeIr.

** Also in Two Vols, entitled "British Animals and Birds," "Foreign Animals and Birds," 1s. each, plain; 2s. 6d, coloured.

Old Nurse's Book of Rhymes, Jingles, and Ditties. Ilustrated by C. H. Bexwetr. Ninety Engravings.

\section{Three Shillings, or gill edges, Three and Sixpence.}

Our Soldierg, or ANECDOTES OF THE CAMPAigNs AND GallaNT Deeds of the Bertish Arsiy pUrivg the Reigy of Her MAJesty Queen Victoria. By W. H. G. Krngston. With Frontispiece. New and Revised Edition. Eighth Thousand.

Our Sailors, or ANECDOTES OF THE ENGAGEMENTS AND GALLANT DeEd8 of trie Britrsh Navy. With Frontispiece. New and Revised Edition, Eighth Thousand.

The Favourite Picture Book and Nursery Companion. Compiled anew by UxcLe ChaRLis. With 450 Tllustrations by eminent artists. In Two Vols., Cloth elegant (or coloured Illustrations, price 5s.)

May also be had in the following styles. One Vol., Cloth, 5s., or coloured Illustrations, gilt, 10s. 6d. Four Parts, paper eovers, 1s. each, or coloured Hlustrations, $2 s$. each.

Fruits of Enterprise, eximbited IN TIIE Travels of Beizoni IN Egrpt Axd Nubu, With Six Engravings by Birket Foster. 
Two Shillings and Sixpence plain, Super Royal 16mo, cloth elegant, with Illustrations by Harrison Weir and others.

Adventures and Experiences of Biddy Dorking and of the Fat Frog. Edited by Mrs, S, C. HaxL.

Amy's Wish, and What Came of It. By Mrs. Truev.

Animals and their Social Powers. By Mary Turser-Axdrewes.

Cat and Dog, or Mremorks of Pess axd thre Captars.

Crib and Fly; a Tale of Two Terriers.

Doll and Her Friends (The), or Memorns of THE LAdy Serapmsa.

By the Author of "Cat and Dog."

Early Dawn (The), or Stories to THINk $\Lambda$ Bovt.

Every Inch a King, or The Story of Rex AxD mrs Frrexds. By

Mrs, J. Worthington Burss.

Fairy Gifts, or A Wallex of Woxders. By Kathleen Kxox.

Funny Fables for Little Folks.

Fun and Earnest, or RHrsmes wrru Reasos. By D'Anor W.

Thompson. Illustrated by C. H. Bexnetr. Imperial $16 \mathrm{mo.}$

Gerty and May. Eighth Thousand.

By the same Author.

Granny's Story Box. New Edition. With 20 Engravings. Children of the Parsonage. Our White Violet.

The New Baby.

Sunny Days, or A Mosri AT THE Great Stowe.

Jack Frost and Betty Snow; with other Tales for Wintry Nights and Rainy Days.

Lost in the Jungle; A TALE of THE Ixdux Metrxy. By Avgusta Marryat.

Madelon. By Esther Camt.

Neptune: or The Autobiograpiry of a Newfoundeaxd Dog. Norris (Emina Marryat.) A Week by Themselves.

By the same Author.

Adrift on the Sea. Geoffry's Great Fault. Seaside Home.
Snowed Up.

Stolen Cherries.

What became of Tommy. 


\section{Two Shillings and Sixpence each-continued.}

Odd Stories about Animals : told in Short and Easy Words.

Our Home in the Marsh Land, or Days of Aund Laxg Srxe. By E. L. F.

Scripture Histories for Little Children. With Sixteen Illustrations by JOHN GILBERT.

Costexts :-The History of Joseph-History of Moses - History of our Saviour-The Miracles of Christ.

Sold separately $6 d$. each, plain; 1 s. coloured.

Secret of Wrexford (The), or Stelin Desmond's Secrer. By Esther Carr.

Tales from Catland. Dedicated to the Young Kittens of England. By an Otd Taвby. Seventh Thousand.

Talking Bird (The), or THE LiTrLe GrRt, WHo KNEw wHAT waS GoLNG To HAPPEN. By M, and E. Krris.

Ten of Them, or The Chmprex of Daxenurst. By Mrs. R. M. BRAY.

"Those Unlucky Twins!" By A. LYster.

Tiny Stories for Tiny Readers in Tiny Words.

Tittle Tattle; and other Stories for Children. By the Author of "Little Tales for Tiny Tots," etc.

Trottie's Story Book: True Tales in Short Words and Large Type.

Tuppy, or The Avtobiograpur oe a Doskex.

Wandering Blindfold, or A Boy's Troubles. By Mary Arbert.

\section{Trvo Shillings and Sixpence, with Illustrations, cloth elegant, or with gilt edges, Three Shillings.}

Adventures of Kwei, the Chinese Girl. By M. E. B. (Mrs. Gel.tre). Davenport's (Mrs.) Our Birthdays, AND How to Imrrove Them.

" $\quad$ " The Holidays Abroad, or Right at Last.

William Allair, or Rexntsg AwAy to SeA. By Mrs, H. Wood,

\section{Troo Shillings and Sixpence each, Illustrated.}

Among the Zulus: the Adventures of Hans Sterk, South African Hunter and Pioneer. By Lreut.-Coloner A. W, Deaysos, R.A.

Boy's Own Toy Maker (The): a Practical Illustrated Guide to the useful employment of Leisure Hours. By E. LAxperis, 200 Illustrations. 


\section{Two Shillings and Sixpence each-continued.}

The Cruise of Ulysses and His Men; or, Tales and Adventures from the Odyssey, for Boys and Girls. By C. M. BetL. With Seven Illustrations by P. Priolo. Feap. 8vo.

Girl's Own Toy Maker (The), AND Book of Recrestion. By E. and A. LAxDELLs. With 200 Mllustrations.

The Guests of Flowers: A Botanical Sketch. By Mrs, MeEtKkRKE. With Prefatory Letter by Dr. TheODore Kerser. Cloth, small 4to.

Little Child's Fable Book. Arranged Progressively in One, Two and Three Syllables. 16 Page Illus. (4s, 6d, coloured, gilt edges.)

Little Pilgrim (The). Revised and Mlustrated by HzLex Petrie. Model Yachts, and Model Yacht Sailing: How to Bumb, Rig, axd Sam a Self-Acting Model Yacht. By Jas, E. Walton, V.M.Y.C. Feap. 4 to, with 58 Woodeuts.

Silly Peter: A Querr Story of a Dart Bor, A Prisce, AND A Mthler's Dadghter. By W. Norris.

Spring Time; or, Words in Season. A Book for Girls. By SIDNEY Cox. Third Edition.

\section{A NEW UNIFORM SERIES OF HALF-CROWN BOOKS. Cloth elegant, fully Illustrated.}

African Pets: or, Chats about our Anmex. Friends in Natal. Wrth a Sketcil of Kaffir Lime. By F. Cinstos Parre.

Bunchy : or, The Chulden of Scarsbrook Furm. By Miss E, C. Piulcres, Author of "The Orphans," \&c.

A Daring Voyage across the Atlantic, by Two Americans, the Brothers Axprews, in a small Bont, the Nautilus. The Log of the Voyage by Captain W. A. Axprews, with Introduction and Notes by Dr. Macsulax, Editor of the Boy's Own Paper.

Hilda and Her Doll. By E. C. Purlurs, Author of "Bunchy," \&c.

The House on the Bridge, and other Tales. By C. E. Bowex, Anthor of "Among the Brigands," \&e,

Kitty and Bo: or, Twe Story of a Very LrTrue Grre AND Box. By A. T. With Frontispiece.

On the Leads: or, What the Praxets Saw. By Mrs, A, A. Straxge Butsox.

Two Rose Trees: The Adventures of Twin Sisters, By Mrs. Minsie Douglas.

Ways and Tricks of Animals, wrth STormes ABOet Aust MARY's Pets, By Mary Hoorer. 


\section{COMICAL PICTURE BOOKS.}

Two Shillings and Sixpence each, Coloured Plates, fancy boards.

English Struwwelpeter (The): or Preity Storiss axd Funxy Pictures for LitTLE ChILDREn. After the celebrated German Work, Dr. Herseich Hofrsass. Twenty-sixth Edition. Twenty-four pages of Illustrations (or mounted on linen, 5s.)

Funny Picture Book (The); or 25 Fussy Lirtle Lessoss. A free Translation from the German of "Der Kuerse, A.B.C. Scuütz." Paper Boards.

Loves of Tom Tucker and Little Bo-Peep. Written and Mlus. trated by Thомаs HooD.

Spectropia, or Surprisivg Spectral Illusions, showing Ghosts everywhere, and of any colour. By J. H. Brows.

Upside Down : a Series of Amusing Pietures from Sketehes by the late W. McCossels, with Verses by Thomas Hoon.

Two Shillings, cloth elegant, with Illustrations, or with coloured plates, gilt edges, Three Shillings.

Fanny and Her Mamma, or, Easy Lessons for CHiddres.

Good in Everything, or THE EArLx Hrstory of Girbert HARLAND. By Mrs. BARWELI.

Little Lessons for Little Learners, in Words of One Syllable. By Mrs. Barwel.t.

Mamma's Bible Stories, for Her Ltrtum Bors AND Grels. Mamma's Bible Stories (A Sequel to).

Mamma's Lessons, yoR HER LitTle Boys aNd GrRLs.

Silver Swan (The); a Fairy Tale. By Madame de Chatelars.

Tules of School Life, By AgNes Loudor.

Wonders of Home, in Eleven Stories (The). By Grasdfather GREY.

\section{Two Shillings each.}

Confessions of a Lost Dog (The). Reported by her Mistress, Fraxoes Power ConBe. With a Photograph of the Dog from Life, by Frank Haes.

Home Amusements : a Choice Collection of Riddles, Charades, Conundrums, Parlour Games, and Forfeits.

How to Make Dolls' Furniture AND to Furnish a DoLL's House. With 70 Illustrations. Small 4 to.

Illustrated Paper Model Maker. By E. LAxdells.

Scenes of Animal Life and Character, Fros NATURE AND Recollection. In Twenty Plates. By J. B. 4to, fancy boards.

Surprising Adventures of the Clumsy Boy Crusoe (The). By CharLes H. Ross. With Twenty-three Coloured Ilustrations. 


\section{UNIFORM IN SIZE AND STYLE.}

Price One Shilling and Sixpence each, cloth elegant, fully Illustrated.

Angelo; or, The Prse Forest in the Alps. By Geraldine E. JEwsBUKY. 5th Thousand.

Aunt Annette's Stories to Ada. By Axwetre A. Saluman,

Brave Nelly; or, Weak Hands axd a Whirve Heart. By M. E. B. (Mrs. Gellie), 5 th Thousand.

Featherland; or, How the Brrds Lived-at Greentaws. By G. M. FeNN. 4th Thousand.

Humble Life: a Tale of HusBre Homes. By the Author of "Gerty and May," \&c.

Kingston's (W. H. G.) Child of the Wreck: or, THe Loss ov the Royal George.

Lee's (Mrs. R.) Playing at Settlers ; or, THE Faggot Hovse. of Animals. Twelve Stories of the Sayings and Doings

Little Lisette, the Orperan of Alsace. By M.E.B. (Mrs. Gelime). Live Toys ; or, Axecdotes of our Foun-Liegged axd otimer Pets. By EMma Davenport.

Long Evenings; or, Stomes por Mr Lrrtue Friesds. By Emmis Marriat.

Three Wishes (The). By M.E.B. (MrB, Gezlre).

NEW SERTES OF UNIFORM BOOKS AT $1 s .6 d$. EAOH.

All Illustrated. Attractively bound in cloth, printed in red and gold. Adventures in Fanti-land. By Mrs. R. LeE, Author of "The African Wanderers," \&c.

Always Happy, or, Axecdotes of Feirx AXd his Sister Serexa. By a Mother. Twentieth Thousand.

Child's Influence (A), or Kathlees axd mer Gmit Uxcle. By Lisa LOCKYER.

Constance and Nellie; or, the Lost WiL. By Emsa Davenport. Corner Cottage, and Its Inmates. By Fraxces Osborsx.

Father Time's Story Book for the Little Ones. By Katmues Kxox. From Peasant to Prince, or The Lrfe of Alexaxder MenschiKOFr. By Mrs, Pietzker.

Granny's Wonderful Chair. By Fraxces Browne.

Happy Holidays; or, Brothers and Sisters at Hoye. By Emra DAVESTORT. 
One Shilling and Sixpence each-continued.

Kingston (W. H. G.) The Heroic Wife; or, The Advextunes of A FAMILY ON THE BANKs OF THE AMAZON.

Lucy's Campaign : a Story of Adventure. By Marx and Catherine Liee,

My Grandmother's Budget of Stories AXD Verses. By Mrs. BRODERIP.

\section{Price One Shilling and Sixpence each.}

Every-Day Things, or UsEFul KNowLEdeE RESPECTING THE PRIScipal Aximal, Vegetable, axd Mineral Substaxces is COMMON USE.

Little Roebuck (The), from the German. Illustrated by Lossox. Fancy boards (2s, coloured).

Taking Tales. Edited by W. H. G. Krngston. In Plain Language and large Type. Four vols.

May also be had in Two vols, $3 s, 6 d$. each; and in 12 parts, paper covers, price 4d. each; or cloth limp, 6d. each.

Trimmer's (Mrs.) New Testament Lessons. With 40 Engravings.

A NEW UNIFORM SERIES OF BOOKS AT $1 s$. EACH. All Illustrated. Attractively bound in cloth, printed in silver and gold.

Alice and Beatrice, By Graxdmanna.

Among the Brigands, and other Tales of Adventure. By C. E. BOWEN.

Children's Pienic (The) : and What Came of it. By E. Markyat Norris.

Christian Elliott: or Mrs, Dasver's Prize. By L. N. Comys, Fourth Thousand,

Discontented Children (The,) AND HOW THEY WERE CuRED. By M. and E. KrRBY.

Grandmamma's Relies, AND HER Storres $\triangle$ BOLt thes. By C. E. Bowen.

Harry at School. A Story for Boys. By E. Markyat Norrts.

Holiday Tales. By Flonesce Wriford.

Holidays among the Mountains, or SCENES AXD STORIES or WALEs. By M. Betham Edwards.

Julia Maitland, or, Pride goes before a Fall. By M. \& E, Kirby. Paul Howard's Captivity, AXD WHY He Esouped. By E. Markyat Norris,

Wrecked, Not Lost ; or, The Priot and mis Companion. By the Hon. Mrs. Dunda8. Fifth Thousand. 


\section{THE FAVOURITE LIBRARY.}

New Editions of the Volumes in this Series are being issued, and other Volumes by Popular Authors will be added.

Cloth elegant, with coloured frontispiece and title-page, One Shilling each.

1. The Eskdale Herd Boy. By Lady Stoddart,

2. Mrs, Leicester's School. Bx Chartes and Mary Lamb.

3. The History of the Robins. By Mrs. Trimmer.

4. Memoir of Bob, The Spotted Terrier.

5. Keeper's Travels in Search of His Master,

6. The Scottish Orphans. BY LAdY StodDART.

7. Never Wrong; or, the Young Disputant; \& It was only in Fun.

8. The Life and Perambulations of a Mouse.

9. The Son of a Genius. BY Mrs. HoFlaxd.

10. The Daughter of a Genius. Bx Mrs. Hoflaxt.

11. Ellen, the Teacher. By Mrs. Hortand.

12. Theedore; or The Crusaderg. Br Mrs. Hoftaxd.

13. Right and Wrong. By the Author of "Always Happr."

14. Harry's Holiday. BY JefFerys TAYLOR.

15. Short Poems and Hymns for Children.

Price One Shilling each, in various styles of binding.

The Picturesque Primer. Paper Boards.

Fragments of Knowledge for Little Folk. Paper Boards.

Easy Reading for Little Readers. Paper Boards

The Nursery Companion. Paper Boards.

These Four Volumes contain about 450 pictures. Each one being complete in itself, and bound in an attractive paper cover, in boards (also with coloured Illustrations, 2s.), or in Two Vols., cloth, 3s., or coloured Illustrations, 5 s.

The Four Volumes bound together form the "Favourile Picture Book," bound in cloth, price 5s, or coloured Illustrations, gilt edges, 10 s. $6 d$.

Australian Babes in the Wood (The): a True Story told in Rhyme for the Young. Price $1 s$. boards, $1 s, 6 d$, cloth, gilt edges.

Cowslip (The). Fully Illustrated eloth, $1 s$. plain; $1 s .6 d$. coloured. Daisy (The). Fully Illustrated cloth, 1 s. plain: $1 s, 6 d$. coloured.

Dame Partlett's Farm. Ax Account of the Riches she obtarned BY IxDUstry, \&c. Coloured Illustrations, sewed.

Female Christian Names, AND them Trachings. A Gift Book for Girls. By MArx E, Brommirt. Cloth, gilt edges

Golden Words for Children, ғвом tme Book or LiFe. In English, French, and German. A set of Mluminated Cards in Paeket. Or bound in eloth interleaved, price $2 s .6 d$. gilt edges. 


\section{One Shilling each-continued.}

Goody Two Shoes: or The History of Litrle Mareery MeasWELL IN RHYME. Fully Illustrated, cloth.

Hand Shadows, to be thrown upon the Wall. Novel and amusing figures formed by the hand. By Hexry Bursint. New and cheaper Edition. Twelfth Thousand. Two Series in one. (Or coloured Illustrations, $1 s .6 d$.)

Headlong Career (The) and Woeful Ending of Precocious Piggy. By Tном Fancy wrapper, 4to. (Or mounted on cloth, untearable, 2s.)

Johnny Miller; or Truth and Perseverance. By Felix Weiss.

Nine Lives of a Cat (The) : a Tale of Wonder. Written and Jllustrated by C. H. BEnxeTr. 24 Coloured Engravings, sewed.

Peter Piper. Practical Principles of Plann and Prgfect Prosuncution. Coloured Illustrations, sewed.

Plaiting Pictures. A Novel Pastrare By which CHILdREN dax CONSTRUCT AND RECONSTRECT PICTURES FOR THEMSELVES. Four Series in Fancy Coloured Wrappers. Oblong 4 to.

First Series.-Juvenile Party-Zoological Gardens-The Gleaner.

Second Series.-Birds' Pic-nie-Cats' Concert-Three Bears.

Third Series.-Blind Man's Buff-Children in the Wood-Snow Man.

Fourth Series.-Grandfather's Birthday-Gymnasium-Playroom.

Primrose Pilgrimage (The) : a Woodland Story. By M. Bетним EDwards. Illustrated by Macevord. Sewed.

Rhymes and Pictures about Bread, Tea, Sugar, Cotron, Coals, and Gold. By Writua Newarax. Seventy-two Illustrations. Price 1s. plain; 2s, 6d, coloured.

* * Each Subject may be had separately. $6 d$. plain; 1s. coloured,

Short and Simple Prayers, with Hymns for the Use of Children. By the Author of "Mamma's Bible Stories." Sixteenth Thousand. Cloth.

Whittington and his Cat. Coloured Illustrations, sewed.

Young Vocalist (The). A Collection of Twelve Songs, each with an Accompaniment for the Pianoforte. By Mrs. Mounser Buntholomsw. New and Cheaper Edition. (Or bound in eloth, price 2s.)

\section{DURABLE NURSERY BOOKS.}

Mounted on cloth with coloured plates, One Shilling each.

1. Cock Robrs.

2. Couktship of Jenny Wren. 4. House that Jack Bunt. 5. Puss is Boots. 
Price Sixpence each, Plain; One Shilling, coloured. HLUBTRATED BY HARUISON WEIR AND JOHS GILBERT.

1. British Animals, lst Series.

2. British Animnls. 2nd Series.

3. British Birds.

4. Foreign Animals. 1st Series.

5. Foreign Animals. 2nd Series.

6. Foreign Birds.

7. The Farm and its Scenes.
8. The diverting History of John Gilpin.

9. The Peacock's Home and Butterây's Ball.

10. History of Joseph.

11. History of Moses.

12. Life of our Saviour.

\section{Miracles of Christ}

His Name was Hero. Price 1s, sewed. By the same Author.

How I became a Governess. 3rd Bdit. 2s. eloth; $2 \mathrm{~s}$, 6d. gilt edges.

My Pretty Puss. With Frontispiece. Price 6d.

The Hare that Found his Way Home

\section{WORKS FOR DISTRIBUTION.}

A Woman's Secret; or, How ro auks Hoses Happy, Thirty-third Thousand. $18 \mathrm{mo}$, price $6 d$.

By the same Author, uniform in size and price.

Woman's Work; or, How surs cAs Hris tнe Sick. 19th Thousand.

A Chapter of Aocidents; or, Tax Motran's Assistams ret CAsfs of Burss, Bearps, Cets, de. Ninth Thousand.
Pay to-day, Trust to-morrow; illustrating the Evils of the Tully Bystem. Seventh Thousand.

Nursery Work; or, Haxsau BAXxR's Frist Puncr. Fifth Thousand.

The Cook and the Dootor; or, Chrsa

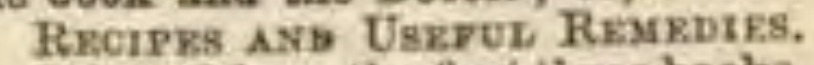
Selected from the first three books. Price $2 d$.

Home Diffioulties, A Few Words on the Servant Question. 4d.

Family Prayers for Cottage Homea. Price 2d.

\section{Price 9d. each, elegantly bound in Paper Boards, with Covers} in Chromolithography.

\section{THE TINY NATURAL HISTORY SERIES}

OF BTORY BOOKS ABOUT ANIMALS FOR LTTTIE READERS.

ALE PROFUSELY ILLUSTRATED BY THE BEST ARTISTA.

Bspeciully adapted for Sunday Sohool Prizes and Rewards. In one way or another, the books either impart knowledge about Animals or inculeate the desirableness of treating them with kindness.

Little Nellie's Bird Cage, By Mrs. R. LEF, Author of "The African Wanderers," \&ce.

The Tiny Menagerie, By Mrs. R. LEe, Author of "The African Wanderers," \& 0 .

The Dog Postman. By the Author of "Oda stories,"

Tho Misohievous Monkey. By the Author of "Odd Stories,"

Iily's Ietters from the Farm. By MAny Hoopke, Author of "Ways und Tricks of Animals."

Our Dog Prin. By Marx Hoopkr, Author of "Ways and Tricks of Animals,"

The above 12 vols, in Cardboard Box with Pieture Top, price $9 s$.
Little Neddie's Menagerie. By Mrs. R. LeE, Author of "The African Wanderers," \&c.

Froliosome Frisk and his Friends. By the Author of "Trottie's story Book."

Wise Birds and Clever Dogs. By the Anthor of "Tuppy," "Tiny Stories," \&ce.

Artful Pussy. By the Author of "Odd Btories," \&c.

The Pet Pony. By the Author of "Trottie's Story Book."

Bow Wow Bobby. By the Author of "Tuppy," "Odd Stories," \&c. 
In 12 Parts, cloth limp, fancy binding, with Chromo on side Price $6 d$. each, or paper covers $4 d$. each.

\section{TAKING TALES.}

Edited by W. H. G. Krostox. Fully illustrated. N.B.-Each Tale is Illustrated and complete in itself.

1. The Miller of Hillbrook: A Rurat. TaLE.

2. Tom Trueman, a SAHon IX A Merouaxtanax.

3. Miohael Hale and his Family in Canada.

4. John Armstrong, THX SoLvrke.

5. Joseph Rudge, тm Avstratias SHEPHKI1.

6. Life Underground; on DicK, тнЕ Colninax Boy.
7. Life on the Coast; on mBg LIтrix Frsuri Grier.

8. Adventures of Two Orphans in London.

9. Barly Days on Board a Man-ofWar.

10. Walter, the Foundling : A TA1s of Oripes Tratss.

11. The Tenants of Sunnyaide Farm.

12. Holmwood: oR, THE NAw ZEALAND SETTEER.

N.B. - May also be had in 4 vols. 1 s, $6 d$. each, and 2 rols. 3 s. 6d, each.

\section{OUR BOY'S LTTTLE LIBRARY.}

\section{PICTURES AND READING FOR LITTLE FOLK.}

A Series of Twelve elegant little volumes in Paper Boards, with attractive Covers in Chromolithography, price 4d. each; or in cloth extra, price 6d. each. The 12 vols. in a Box with Fancy Lid, price 4s. and 6s. Every page is Illustrated.

They are especially suited for Sunday School Prizes and Rewards.

1. Papa's Pretty Gift Book,
2. Mamma's Protty Gift Book,
3. Neddy's Picture Story Book,
4. Stories for Play Time.
5. The Christmas Gift Book,
6. The Prize Pioture Book.
7. Little Tommy's Story Book.

8. Bright Pioture Pages.

9. My Little Boy's Story Book'

10. What Santa Clans gave me.

11. Tiny Stories for Tiny Boys.

12. Little Boy Blue's Pioture Book.

\section{OUR GIRL'S LITTLE LIBRARY.}

\section{PIOTURES AND READING FOR LITTLE FOLK.}

A series of Twelve elegant little volumes in Paper Boards, with attractive Covers in Chromolithography, price 4d. each; or in cloth extra, price 6d. each. The 12 vols, in Box with Fancy Lid, price 4s. and 6s. Every page is Illustrated.

They are especially suited for Sunday School Prizes and Rewards.
1. Nellie's Picture Stories.
2. Stories and Piotures for Little Troublesome.
3. Little Trotabout's Pioture Stories,
4. Birdie's Sorap Book.
5. Stories for Iittle Curly Looks.
6. Bright Piotures for Roguish Eyes.

7. Daisy's Picture Album.

8. Wee-Wee Storieg for Wee-Wee Girls,

9. May's Little Story Book.

10. Gipsy's Favourite Companion.

11. My Own Story Book.

12. Pretty Pet's Gift Book. 


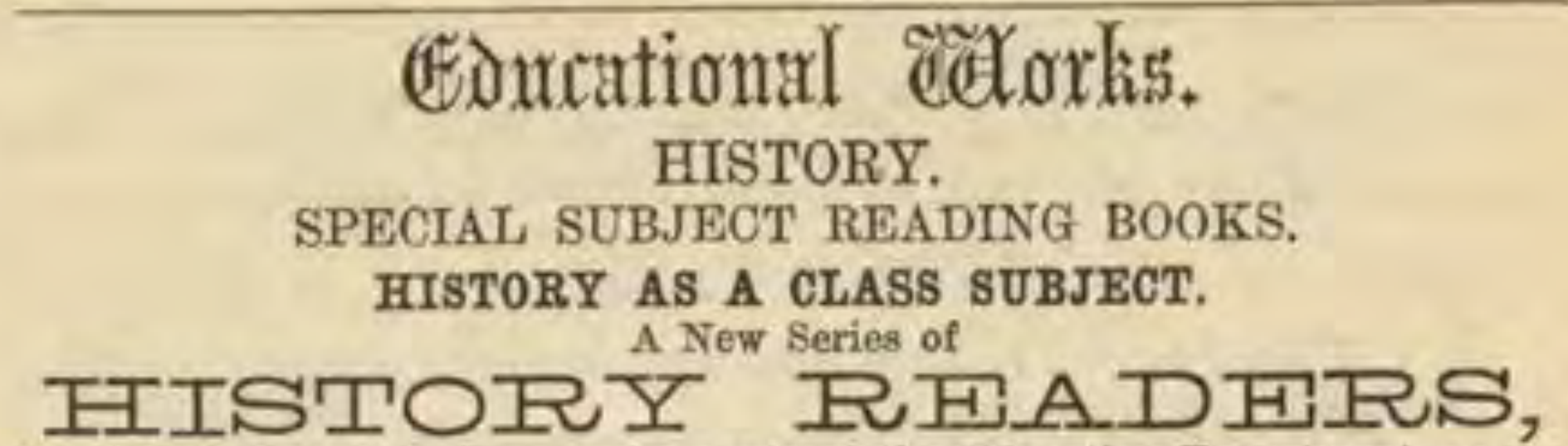

Specially adapted to the requirements of the Education Department, as expressed in a circular to Her Majesty's Inspectors, No, 187. They are written by Mr. H. MAJOR, B.A., B. Sc.

N.B.-Special pains have been taken to secure a strong and durable binding.

History Reader. Part I. British History from B.c. 55 to A.D. 1066. Arranged in Forty Sections. For Standard II, in Elementary Schools, and Juniors in Public and Private Sehools. Uniform with Mr. Buskistos's "Glimpses of the Globe." Cloth limp, price 1s.

History Reader. Part II. Intended for the Use of Standard III. From A.D. 1066 to A,D. 1485. Uniform with the above, 128pp. Cloth, price $1 s$.

History Reader. Part III. Intended for the use of Standard IV. From A.D. 1485 to A.D. 1688. Containing about 192 pp. Cloth, price 1s. $6 d$.

History Reader. Part IV. From A.D, 1688 to A.D, 1880 . Intended for the use of Standards V. and VI. Containing about 192pp. Uniform with the above. Cloth, price $1 s, 6 d$.

Britannia : a Collection of the Principal Passages in Latin Authors that refer to this Island, with Vocabulary and Notes. By T. S. CAYzer. Illustrated with a Map and 29 Woodeuts. Crown 8vo. Price 3s, 6d.

True Stories from Ancient History, chronologically arranged from the Creation of the World to the Death of Charlemagne. $12 \mathrm{mo} ., 5 s$. cloth.

Mrs. Trimmer's Concise History of England, revised and brought down to the present time. By Mrs. MrLner. With Portraits of the Sovereigns. $5 s$, eloth.

Rhymes of Royalty : the History of Fingland in Verse, from the Norman Conquest to the reign of Vrcrorus; with a summary of the leading events in each reign. Feap. 8vo, 2s. cloth.

\section{GEOGRAPHY.}

Pictorial Geography for the Instruction of Young Children. Price $1 s .6 d . ;$ mounted on rollers, $3 s, 6 d$.

Gaultier's Familiar Geography. With a concise Treatise on the Artificial Sphere, and two coloured Maps, illustrative of the principal Geographieal Terms, $16 \mathrm{mo}, 3 s$, cloth.

Butler's Outline Maps, and Key, or Geograpmeal AND BIOGRAPHICAI ExERCIsEs; with a set of Coloured Ontline Maps, designed for the use of Young Persons. By the late Willisu Butler. Enlarged by the Anthor's Son, J. O. Butrer. Revised 4s. 


\section{GEOGRAPHY-continued. \\ SPECIAL NOTICE.}

\section{J. R. BLAKISTON'S GEOGRAPHICAL READING BOOKS.}

The first two Books cover the whole of the knowledge required to secure a Class Grant for Geography, each one containing materials for Eighty Lessons, in 156 pages.

Glimpses of the Globe. A First Geographical Reading Book in forty chapters. By J, R. Blakiston, M.A., Author of "The Teacher," \&c. Cloth, 1 s.

Glimpses of England. A Geographical Reading Book in forty chapters, By J. R. Blakistos, M.A., Author of "The Teacher," \&c. Cloth, $1 s$.

(C2) A few copies of the Supplementary Chapters may bo bought separately, for Schools using the earlier editions of these books. Price 6d, each. Shortly.

Glimpses of the British Empire. By the same Author. A First Geographical Reading Book for the Upper Standards, in 66 Sections. Will be issued in time for Schools teaching Geography as a Class Subject in the School-year ending 30th September, 1881.

And will be followed in due course by

Glimpses of the 01d World (Europe, Africa, and Western Asia). By the same Author. AND

Glimpses of the New World (Eastern Asia and the Americas). By the same Author. For the Second and Third Years' Reading Lessons.

The division of matter has been carefully considered and approved. All five books will be modelled so as to meet the requirements of the Education Department.

\section{GRAMMAR, \&c.}

A Compendious Grammar, aNd Philologrcal, HaNd-Book of the Exglish Langeage, for the use of Schools and Candidates for the Army and Civil Service Examinations. By J. G. ColquHoux, Esq., Barrister-at-Law. Feap. 8vo. Cloth, 2s. 6d,

Darnell, G. Grammar made Intelligible to Children. Being a Series of short and simple Rules, with ample Explanations of Every Difficulty, and copious Exercises for Parsing; in Language adapted to the comprehension of very Young Students. New and Revised Edition. Cloth, 1s.

Darnell, G. Introduction to English Grammar, Price $3 d$. Being the first 32 pages of "Grammar made Intelligible."

Darnell, T. Parsing Simplified : an Introduction and Companion to all Grammars; consisting of Short and Easy Rules, with Parsing Lessons to each. Price 1s. eloth.

Lovechilds, Mrs. The Child's Grammar. 50th Edition. 9d. cloth. 


\section{GRAMMAR-continued.}

A Word to the Wise, or Hists ox THE Cument Improprietres or Expresstox in Writing and Speaktra. By Parky Gwrsxe. 16th Thousand. 6d. sewed; or 1s, cloth, gilt edges.

Harry Hawkins's H-Book; showing how he learned to aspirate his $H^{\prime}$ s. Eighth Thonsand. Sewed, price $6 d$.

Prince of Wales's Primer (The). With 340 Illustrations by J. Ginbert. Price 6d.

Darnell, G. Short and Certain Road to Reading. Being a Series of EA8Y Lessoss in which the Alphabet is so divided as to enable the Child to read many pages of Familiar Phrases before he has learned half the letters. Cloth, $6 d$.; or in Four parts, paper covers, $1 \frac{1}{2} d$, each.

Sheet Lessons. Being Extraets from the above, printed in very large, bold type. Price, for the Set of Six Sheets, (id; or neatly mounted on boards, 3 s.

\section{ARITHMETIO AND ALGEBRA.}

Darnell, G. Arithmetic made Intelligible to Children. Being a Series of Gradually Advancing Exercises, intended to employ the reason rather than the Memory of the Pupil; with ample Explanations of Every Difficulty, in Language adapted to the comprehension of very young Students. Cloth, 1s. $6 d$.

*** This work may be had in Three parts-Part I., price $6 d$. Part II., price 9d. Part III., price 6d. A KEY to Parts II. and III, price 1s. (Part I, does not require a Key.)

Cayzer, T. S. One Thousand Arithmetical Tests, or TrrE Exasmser's Assistant. Specially adapted, by a novel arrangement of the subject, for Examination Purposes, but also suited for general use in Schools. With a complete set of Examples and Models of Work. Price 18. 6d.

Key with Solutions of all the Examples in the One Thousand Arithmetical Tests. 4s, $6 d$. cloth. The Answers only, $1 s .6 d$.

One Thousand Algebraical Tests; on the same plan. 8vo, price 2s. 6d. cloth.

Axswers to the Algebraical Tests, price $2 s .6 d$. cloth.

Theory and Practice of the Metric System of Weights and Measures, By Prof. Leone Levi, F.S.A., F.S.S. Sewed 1 s.

Essentials of Geometry, Plane and solid (The), as taught in Germany and France. By J. R. Morel., Numerous Diagrams. $2 s$, eloth.

Artizan Cookery and How to Teach it. By a Pupil of the National Training School for Cookery, South Kensington. Sewed, price $6 d$. 


\section{NEEDLEWORK.}

By the Senior Examiner of Needlework to the School Board for London.

Plain Hints for those who have to Examine Needlework, whether for Government Grants, Prize Associations, or Local Managers, to which is added Skeleton Demonstration Lessons to be nsed with the Demonstration Frames, and a Glossary of terms used in the Needlework required from the seholars in public elementary schools. Price 2s.

\section{NEEDLEWORK DEMONSTRATION SHEETS}

Exhibit by Diagrams and Deseriptions, the Formation of Stitches in Elementary Needlework. The size of the Sheets is $30 \times 22$ inches.

Price $9 d$. each; or, mounted on rollers and rarnished, 2s. $6 d$.

Whip Stitch for Frills and

Fern or Coral Stiteh $\ldots 1$ Sheet

Hemming, Seaming, and

Stitehing $\ldots \ldots \ldots 1$...

Button Fole … .... ... 1 ,"

Fisherman's Stitoh for Braid-

ing Nets $\quad \ldots \quad \ldots \ldots \ldots 1, \ldots$

Herring Bone ,... ........ 1 ,

Grafting stocking Material... I ",

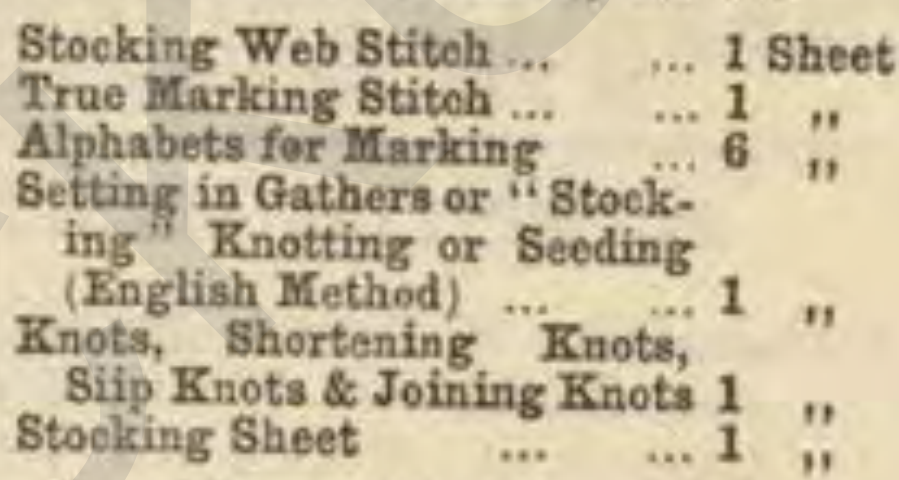

The Demonstration Frame for Class Teaching, with Special Needle and Cord. Price complete, $78,6 d$.

Plain Needlework arranged in Six Standards, with Hints for the Management of Classes, and Appendix on Simultaneous Teaching. Twentieth Thousand. Price $6 d$.

Plain Knitting and Mending arranged in Six Standards, with 20 Diagrams. Thirteenth Thousand. Price 6d.

Plain Cutting Out for Standards IV., V., and VI., as now required by the Government Edueational Department. Adapted to the principles of Elementary Geometry. Sixth Thousand. Price $1 s$.

A set of the Diagrams referred to in the book may be had separately, printed on stout paper and enclosed in an envelope. Price $1 s$.

* * These works are recommended in thie published Code of the Educational Department.

Needlework Schednle III. Exemplified and IIIustrated. Intended for the use of Young Teachers and of the Upper Standards in Elementary Schools. By Mrs, E, A. Cukris. Cloth limp, with 30 Illnstrations, 6th Thousand, price 1s. 


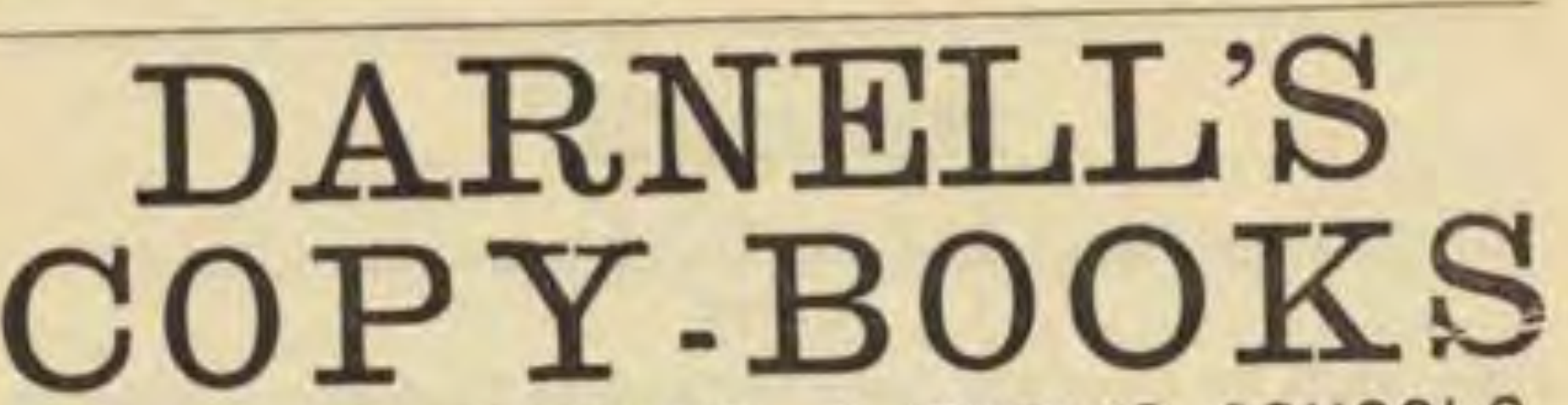

FOR BOARD, PRIVATE, \& PUBLIC SCHOOLS. Adapted to the Grades of the New Educational Code.

\section{DARNELL'S LARGE POST COPY-B00KS, 16 Nos., $6 \mathrm{~d}$. each.}

The first ten of which have, on every alternate line, appropriate and carefullywritten copies in Pencil-coloured Ink, to be first written over and then imitated, the remaining numbers having Black Head-lines for imitation only, Trz wuol.s. GBADUALY ADVANCING FHOM A STMPLE STROKE TO A SUPEROR SMALI, HASD.

DARNELL'S FOOLSCAP COPY-B00KS,

24 Nos., oblong, 3d. each, on the same plan;

or, Superior'Paper, Marble Covers, 4d. each.

DARNELL'S UNIVERSAL COPY-BOOKS,

16 Nos., 2d. each, on the same plan.

ELEMENTARY FRENCH AND GERMAN WORKS.

L'Abécédaire of French Pronunciation: A Manual for Teachers and Students. By G. LEPkívost, of Paris, Professor of Languages. Crown 8vo, cloth, 2s.

Le Babillard: an Amusing Introduction to the French Language. By a Frexch Lady. Ninth Edition. 16 Plates. 2s. cloth.

Les Jeunes Narrateurs, ou Pertrs Contrs Moracx. With a Key to the difficult Words and Phrases. 3rd Edition. 2s. cloth.

Pictorial French Grammar (The). For the use of Children. By MARIN de LA Vore. With 80 Illus. Royal $16 \mathrm{mo}, 1 \mathrm{~s} .6 \mathrm{~d}$. eloth.

Rowbotham's New and Easy Method of Learning the French Genders. New Edition. 6d.

Bellenger's French Word and Phrase Book; containing a select Voeabulary and Dialogues. New Edition. Price 1 s.

Der Sehwatzer, or The Prutrler. An Amusing Introduction to the German Language. Sixteen Illustrations. Price 2s, cloth.

$$
\text { GRIFFITH \& FARRAN, }
$$

WEST CORNER OF Sr. PAUL'S CHURCHYARD, LONDON. E. P. DUTTON ASD CO., NEW YORK. 


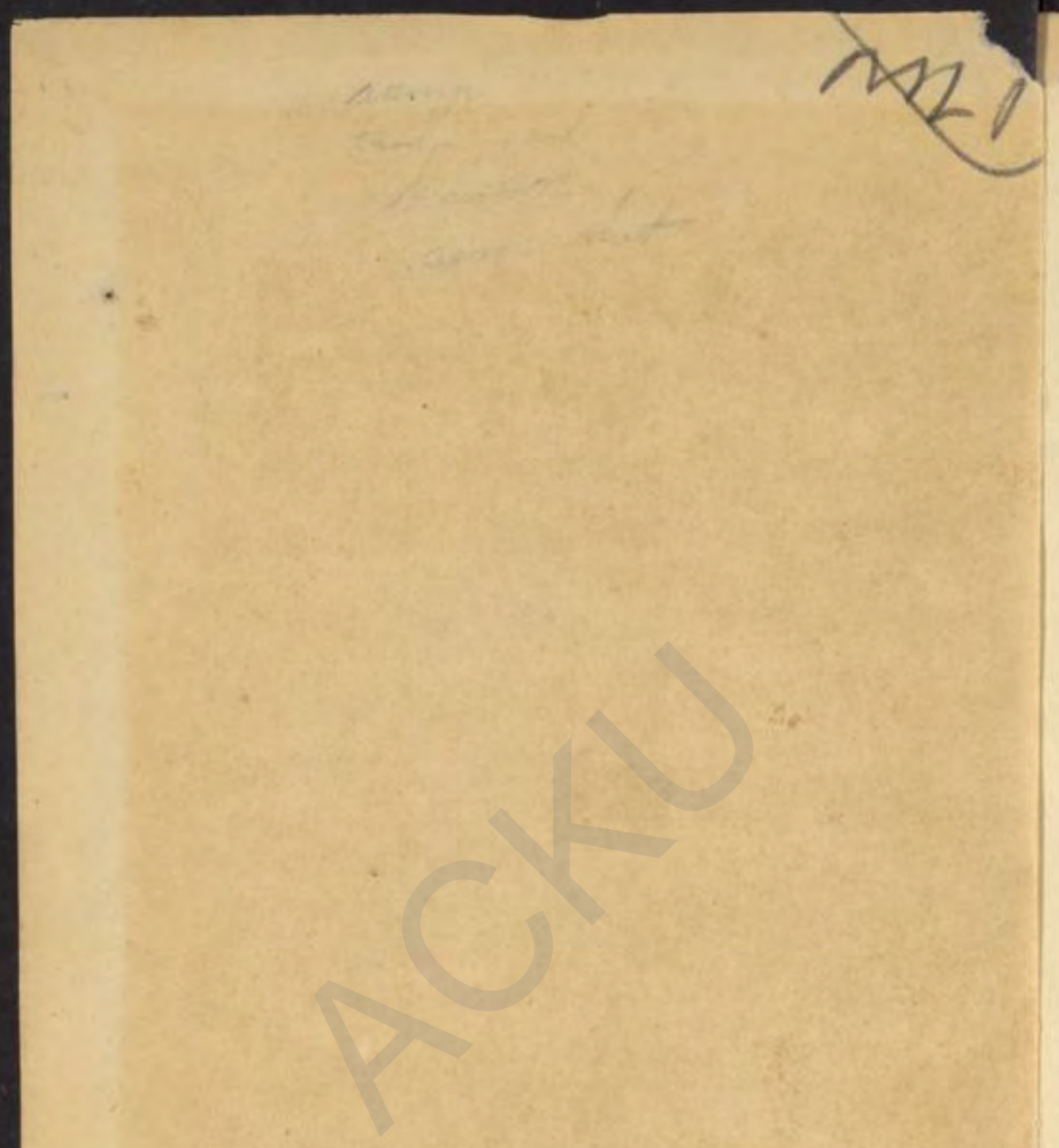

nerop 
